Pacific Northwest

National Laboratory

Operated by Battelle for the

U.S. Department of Energy

\title{
Results of Detailed Hydrologic Characterization Tests Fiscal Year 2003
}

\author{
F. A. Spane \\ D. R. Newcomer
}

September 2004

Prepared for the U.S. Department of Energy

under Contract DE-AC06-76RL01830 


\title{
DISCLAIMER
}

This report was prepared as an account of work sponsored by an agency of the United States Government. Neither the United States Government nor any agency thereof, nor Battelle Memorial Institute, nor any of their employees, makes any warranty, express or implied, or assumes any legal liability or responsibility for the accuracy, completeness, or usefulness of any information, apparatus, product, or process disclosed, or represents that its use would not infringe privately owned rights. Reference herein to any specific commercial product, process, or service by trade name, trademark, manufacturer, or otherwise does not necessarily constitute or imply its endorsement, recommendation, or favoring by the United States Government or any agency thereof, or Battelle Memorial Institute. The views and opinions of authors expressed herein do not necessarily state or reflect those of the United States Government or any agency thereof.

\author{
PACIFIC NORTHWEST NATIONAL LABORATORY \\ operated by \\ BATTELLE \\ for the \\ UNITED STATES DEPARTMENT OF ENERGY \\ under Contract DE-AC06-76RL01830
}

Ty 


\title{
Results of Detailed Hydrologic Characterization Tests - Fiscal Year 2003
}

\author{
F. A. Spane \\ D. R. Newcomer
}

September 2004

Prepared for

the U.S. Department of Energy

under Contract DE-AC06-76RL01830

Pacific Northwest National Laboratory

Richland, Washington 99352 


\begin{abstract}
This report provides the results of detailed hydrologic characterization tests conducted within selected Hanford Site wells during fiscal year 2003. Detailed characterization tests performed included groundwater-flow characterization, barometric response evaluation, slug tests, single-well tracer tests, constant-rate pumping tests, and in-well vertical flow assessments. Hydraulic property estimates obtained from the detailed hydrologic tests include hydraulic conductivity, transmissivity, specific yield, effective porosity, in-well lateral flow velocity, aquifer-flow velocity, vertical distribution of hydraulic conductivity (within the well-screen section), and in-well vertical flow velocity. In addition, local groundwaterflow characteristics (i.e., hydraulic gradient and flow direction) were determined for the site where detailed well testing was performed. Results obtained from these tests provide hydrologic information that support the needs of RCRA waste management area characterization and site-wide groundwater monitoring and modeling programs and reduces the uncertainty of groundwater-flow conditions at selected locations on the Hanford Site.
\end{abstract}




\section{Summary}

The U.S. Department of Energy's Groundwater Performance Assessment Project, managed by Pacific Northwest National Laboratory, examines the potential for offsite migration of contamination within aquifer systems underlying the Hanford Site. An important characterization element that helps define the migration of contamination is the analysis of hydrologic tests, which provide estimates of hydraulic properties for the tested aquifer systems. Information gained from the analysis of hydrologic tests is important when evaluating aquifer-flow characteristics (i.e., groundwater-flow velocity) and transport travel time, which are key parts of effective groundwater monitoring and modeling. Obtaining representative information about the hydraulic properties of the unconfined aquifer beneath the Hanford Site can be complicated by temporal changes in the water-table elevation and associated aquifer thickness. In particular, earlier hydrologic tests in the 200-West and 200-East Areas may reflect overlying, hydrogeologic units that are no longer saturated and are not part of the current groundwater flow system. Obtaining current information on hydraulic properties of the aquifer provides a way to assess the reliability and/or representativeness of earlier data and provides up-to-date information that can be used for effective groundwater monitoring and modeling.

This report presents test results obtained from the detailed hydrologic characterization program of the unconfined aquifer system conducted for the Groundwater Performance Assessment Project during fiscal year (FY) 2003. Hydrologic tests conducted as part of the detailed program include the following:

- slug testing (7 wells tested)

- tracer-dilution tests (1 well tested)

- tracer-pumpback tests (1 well tested)

- constant-rate pumping tests (1 well tested)

- vertical flow, in-well assessment (1 well tested)

Hydrologic test results conducted during FY 2003 reflect the properties of Ringold Formation gravel Unit E (Unit 5) for wells tested in the 200-West Area and reflect the properties of the Hanford formation (Unit 1) for wells tested in the 200-East Area. Hydraulic property estimates obtained from the detailed hydrologic tests include hydraulic conductivity, transmissivity, specific yield, effective porosity, in-well lateral groundwater-flow velocity, aquifer groundwater-flow velocity, vertical distribution of hydraulic conductivity, and in-well vertical flow velocity. Specifically, the well selected for detailed tracer-dilution and pumpback testing (i.e., well 299-E26-10) provides hydrologic characterization information for the unconfined aquifer within the Liquid Effluent Retention Facility (LERF). In addition, local groundwaterflow characteristics (i.e., hydraulic gradient, flow direction) were determined for this LERF site location. The unconfined aquifer at this locality is particularly thin (i.e., $\sim 2 \mathrm{~m}$ ), due to historic water-table lowering and occurs within sediments of the Hanford formation and underlying Elephant Mt. basalt flowtop. Pertinent results from the FY 2003 detailed characterization program are summarized in the following paragraphs. 
Slug-test results provided hydraulic conductivity estimates that ranged between 3.0 and $64.1 \mathrm{~m} /$ day for the two 200-West Area wells (representative of the Ringold Formation gravel Unit E - Unit 5) and between 39.8 and $104 \mathrm{~m} /$ day for four 200-East Area wells (representative of the Hanford formation Unit 1). In addition, one 200-East Area well was tested that provided hydraulic conductivity estimates that ranged between 5.85 and $6.80 \mathrm{~m} /$ day that are representative of the Elephant Mt. basalt flowtop. These results are consistent with previously reported hydraulic property values for these hydrogeologic units (e.g., Elephant Mt. basalt (Spane and Vermeul 1994; Spane and Webber 1995).

A comparison of the slug-test-derived hydraulic conductivity estimate at well 299-E26-10 (average type-curve analysis value; $\mathrm{K}=39.8 \mathrm{~m} /$ day) with the value obtained from the constant-rate pumping test $(\mathrm{K}=36.2 \mathrm{~m} /$ day $)$ indicates a very close correspondence. This is well within previous, more extensive comparisons, between the two test methods (e.g., as noted in Spane et al. 2002).

Analysis of the constant-rate pumping test results for well 299-E26-10 indicates a transmissivity and specific yield value of $71.6 \mathrm{~m}^{2} /$ day and 0.128 , respectively. Even though the aquifer is thin at this LERF locality, no hydraulic boundaries or response characteristics indicative of detachment or perched-water conditions were exhibited during the performance of the constant-rate pumping test. These results suggest that the saturated sediments of the Hanford formation at this location are part of the larger, sitewide unconfined aquifer system.

Results of tracer-dilution testing in well 299-E26-10 indicated: a low average in-well lateral groundwater-flow velocity $\left(\mathrm{v}_{\mathrm{w}}=0.0024\right.$ to $0.0042 \mathrm{~m} /$ day $)$; and a slight downward in-well groundwaterflow condition within the Hanford formation section $\left(\mathrm{v}_{\mathrm{v}}=0.0002 \mathrm{~m} / \mathrm{min}\right)$. These extremely low, in-well flow velocity estimates are believed to reflect the low-hydraulic gradient conditions (i.e., $1.9 \mathrm{E}-4 \mathrm{~m} / \mathrm{m}$ ) and relatively high permeability conditions within the unconfined aquifer/test vicinity. A comparison of the in-well tracer-dilution patterns also suggests that the $\sim 0.5 \mathrm{~m}$ of Elephant Mt. basalt flowtop, through which the lower part of the well screen is completed, has a considerably lower hydraulic conductivity than the overlying Hanford formation sediments.

Results from tracer-pumpback testing at well 299-E26-10 provided estimates for effective porosity and aquifer groundwater-flow velocity of 0.373 and $0.0184 \mathrm{~m} /$ day $(6.7 \mathrm{~m} /$ year $)$, respectively. However because of existing test site complexities and uncertainties (e.g., presence of two different hydrogeologic units; small and variable surrounding aquifer thickness), these property values may be considered to be qualitative estimates of LERF site conditions.

Quantitative groundwater-flow characterization was performed using trend-surface analysis of historical water-table elevations of selected LERF monitoring wells surrounding the well 299-E26-10 test site. The results of this characterization substantiate a low-hydraulic gradient condition for the area. Results from the trend-surface analysis of a representative set of five surrounding wells, together with test well 299-E26-10, indicate a consistent value of hydraulic gradient of $0.00019 \mathrm{~m} / \mathrm{m}$, and a predominant northwesterly groundwater flow direction, which parallels the basalt subcrop pattern (i.e., basalt surface above the water table). Additionally, the similarity in well dynamic responses for LERF monitor wells suggests that the Elephant Mt. basalt flowtop is hydraulically communicative with the unconfined aquifer and, therefore, may be considered as part of the unconfined aquifer flow system within the LERF vicinity. 


\section{Acknowledgments}

Several Pacific Northwest National Laboratory staff contributed to the hydrologic tests presented in this report. In particular, Kirk Cantrell provided laboratory and field support for the tracer tests. Tyler Gilmore participated in the performance and data acquisition of some field tests. Alex Mitroshkov performed laboratory bromide analyses on discrete water samples collected during tracer-pumpback tests. Bruce Williams provided identification of hydrogeologic units tested at the well sites. The field-testing personnel and test equipment support provided by Duratek Federal Services, Inc. is also acknowledged.

In addition, Pacific Northwest National Laboratory staff contributed significantly to this report's preparation. Paul Thorne and Stuart Luttrell provided technical peer review comments. Launa Morasch provided editorial review. 


\title{
Nomenclature
}

\author{
$A=$ cross-sectional area within well screen; $\mathrm{L}^{2}$ \\ $\mathrm{b}=$ aquifer thickness; $\mathrm{L}$ \\ $\mathrm{C}=$ tracer concentration in the test interval at time, $\mathrm{t} ; \mathrm{M}$ per $\mathrm{L}^{3}$ \\ $\mathrm{C}_{\mathrm{D}}=$ well slug test response damping parameter; dimensionless \\ $\mathrm{C}_{\mathrm{o}}=$ initial tracer concentration in well at the start of the test; $\mathrm{M}$ per $\mathrm{L}^{3}$ \\ $\mathrm{C}_{\mathrm{t}}=$ average tracer concentration in well at test termination; $\mathrm{M}$ per $\mathrm{L}^{3}$ \\ $\mathrm{g}=$ acceleration due to gravity; $\mathrm{L} / \mathrm{T}^{2}$ \\ $\Delta \mathrm{h}_{\mathrm{w}}=$ water-level change over the last hour; $\mathrm{L}$ \\ $\Delta \mathrm{h}_{\mathrm{ai}}=$ barometric pressure change over the last hour; $\mathrm{L}$ \\ $\Delta \mathrm{h}_{\mathrm{a} \text { i- } 1}=$ barometric pressure change from $2 \mathrm{~h}$ to $1 \mathrm{~h}$ previous; $\mathrm{L}$ \\ $\Delta \mathrm{h}_{\mathrm{a} \text { in }}=$ barometric pressure change from $\mathrm{n}$ hours to (n-1) hour previous; $\mathrm{L}$ \\ $\mathrm{H}_{\mathrm{o}}=$ theoretical slug test stress level; $\mathrm{L}$ \\ $\mathrm{H}_{\mathrm{p}}=$ projected or observed slug test stress level; $\mathrm{L}$ \\ $\mathrm{H}_{\mathrm{p}-\mathrm{out}}=$ projected initial slug test stress level for outer zone analysis; $\mathrm{L}$ \\ $\mathrm{I}=$ hydraulic gradient; dimensionless \\ $\mathrm{K}=$ hydraulic conductivity; $\mathrm{L} / \mathrm{T}$ \\ $\mathrm{K}_{\mathrm{D}}=$ vertical anisotropy $\left(\mathrm{K}_{\mathrm{v}} / \mathrm{K}_{\mathrm{h}}\right)$; dimensionless \\ $\mathrm{K}_{\mathrm{h}}=$ hydraulic conductivity in the horizontal direction; $\mathrm{L} / \mathrm{T}$ \\ $\mathrm{K}_{\mathrm{hx}} / \mathrm{K}_{\mathrm{hy}}=$ horizontal anisotropy; dimensionless \\ $\mathrm{K}_{\text {snd }}=$ hydraulic conductivity of sandpack; $\mathrm{L} / \mathrm{T}$ \\ $\mathrm{K}_{\mathrm{v}}=$ hydraulic conductivity in the vertical direction; $\mathrm{L} / \mathrm{T}$ \\ $\mathrm{L}_{\mathrm{e}}=$ effective well water-column length; $\mathrm{L}$ \\ $\mathrm{L}_{\mathrm{s}}=$ well-screen length; $\mathrm{L}$ \\ $\mathrm{m}=$ saturated thickness of test interval within well-screen section; $\mathrm{L}$ \\ $\mathrm{M}_{\mathrm{i}}=$ initial tracer mass emplaced in well; $\mathrm{M}$ \\ $\mathrm{M}_{\mathrm{r}}=$ tracer mass recovered during pumpback; $\mathrm{M}$ \\ $\mathrm{M}_{\mathrm{w}}=$ tracer mass in well and sandpack at time of pumpback; $\mathrm{M}$ \\ $\mathrm{M}_{50 \%}=50 \%$ of the tracer mass within the aquifer; $\mathrm{M}$ \\ $\mathrm{n}=$ number of hours that lagged barometric effects are apparent; dimensionless \\ $\mathrm{n}_{\mathrm{e}}=$ effective porosity; dimensionless \\ $\mathrm{Q}=$ pumping rate; $\mathrm{L}^{3} / \mathrm{T}$ \\ $\mathrm{Q}_{\text {avg }}=$ average pumping rate; $\mathrm{L}^{3} / \mathrm{T}$ \\ $\mathrm{Q}_{\mathrm{w}}=$ in-well lateral groundwater discharge within the well test interval; $\mathrm{L}^{3} / \mathrm{T}$ \\ $\mathrm{r}_{\mathrm{c}}=$ well casing radius; $\mathrm{L}$ \\ $r_{\mathrm{eq}}=$ equivalent well casing radius; $\mathrm{L}$ \\ $r_{\text {eq-in }}=$ equivalent well casing radius for inner zone analysis; $\mathrm{L}$ \\ $r_{\text {eq-out }}=$ equivalent well casing radius for outer zone analysis; $\mathrm{L}$ \\ $\mathrm{r}_{\mathrm{obs}}=$ radial distance from pumped well to monitor well location; $\mathrm{L}$ \\ $\mathrm{r}_{\text {snd }}=$ sandpack radius; $\mathrm{L}$ \\ $r_{t}=$ equivalent radius of tracer measurement system; $L$
}




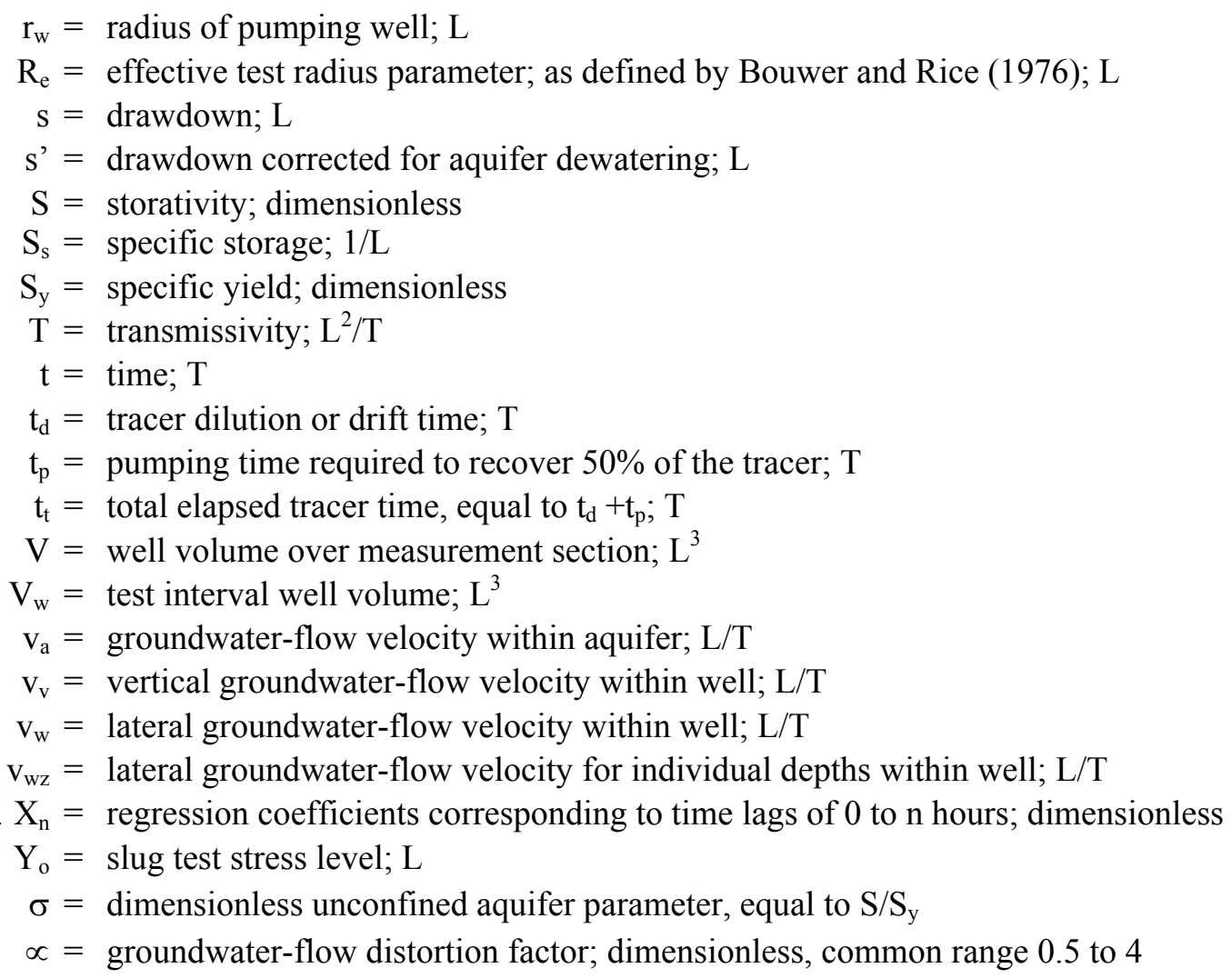




\section{Contents}

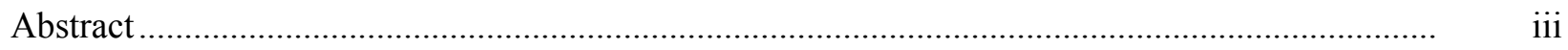

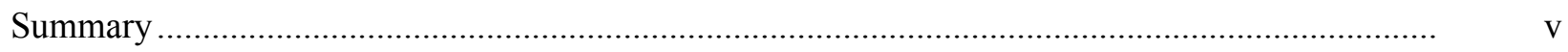

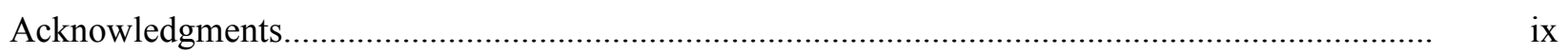

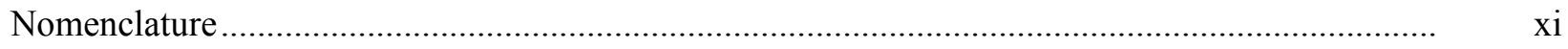

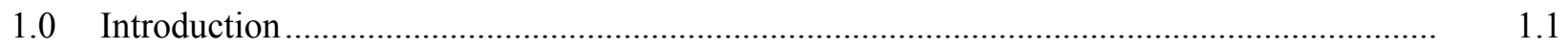

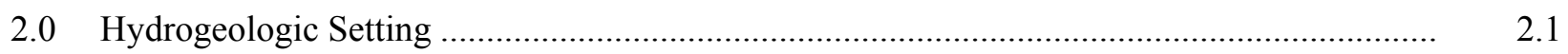

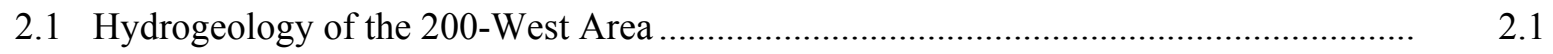

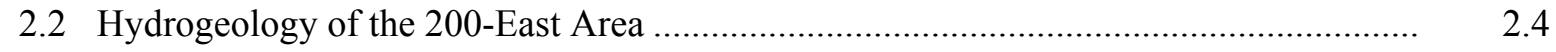

3.0 Detailed Test Characterization Methods …....................................................................

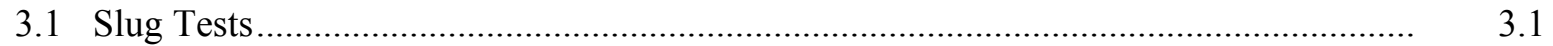

3.1.1 Over-Damped Test Analysis Methods ............................................................. 3.5

3.1.2 High Permeability/Under-Damped Analysis Methods....................................... $\quad 3.11$

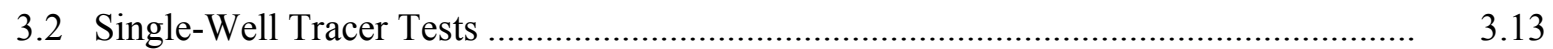

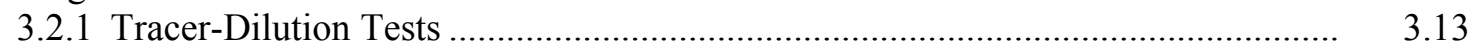

3.2.2 Tracer-Pumpback Tests............................................................................. $\quad 3.14$

3.2.3 In-Well Vertical Flow Assessment .................................................... $\quad 3.16$

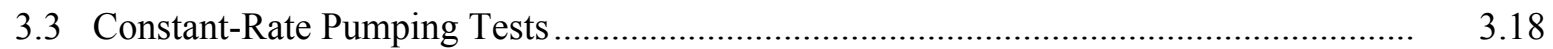

3.3.1 Test Methods and Equipment ..................................................................... 3.18

3.3.2 Barometric Pressure Effects Removal................................................................. 3.18

3.3.3 Unconfined Aquifer Dewatering Drawdown Correction .................................... 3.19

3.3.4 Diagnostic Analysis and Derivative Plots .................................................... 3.20

3.3.5 Type-Curve-Matching Analysis Methods ....................................................... $\quad 3.22$

3.3.6 Straight-Line Analysis Methods..................................................................... 3.23

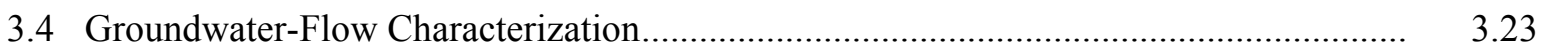

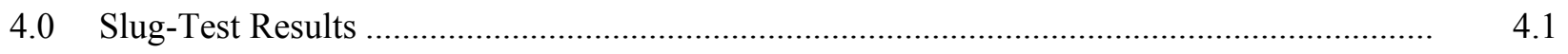

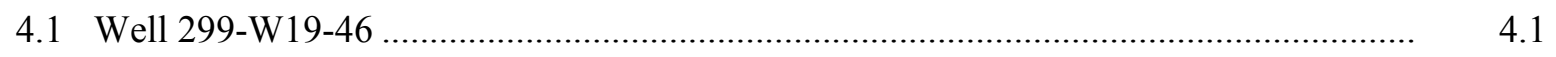

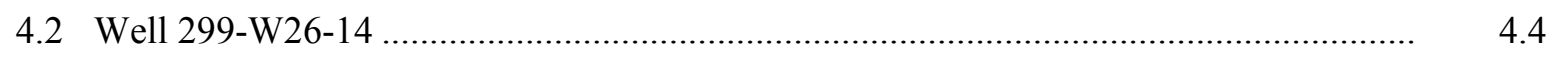

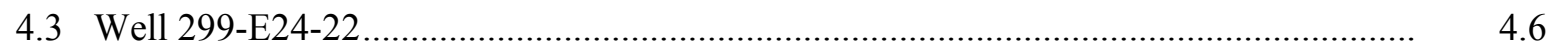




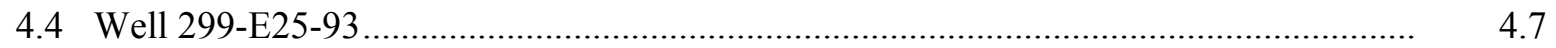

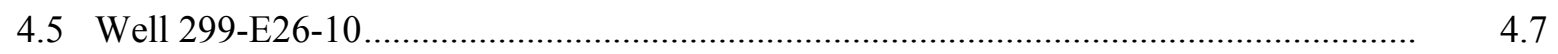

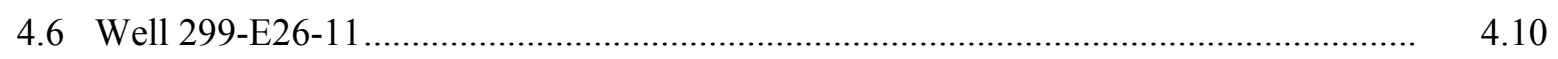

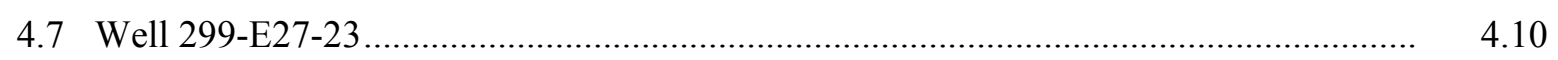

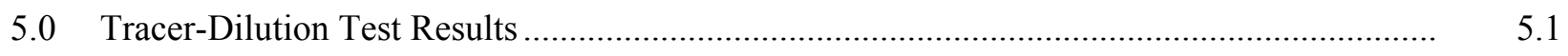

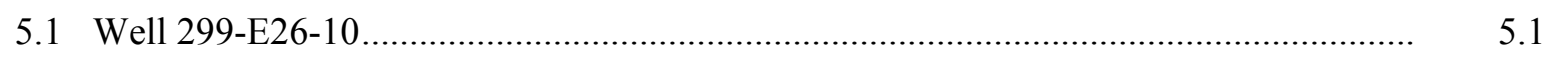

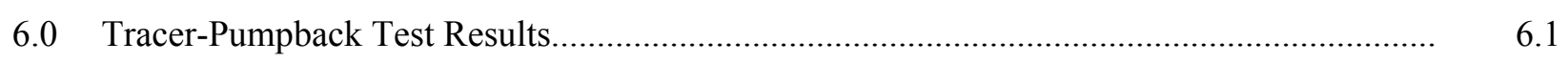

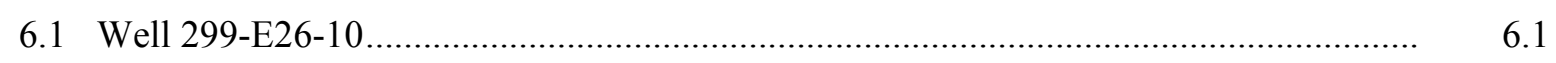

7.0 Constant-Rate Pumping Test Results .....................................................................

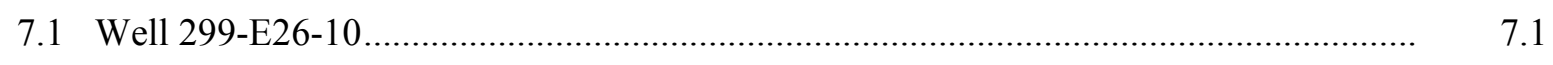

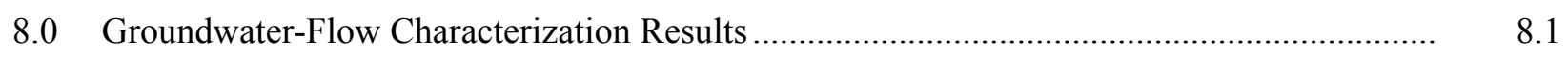

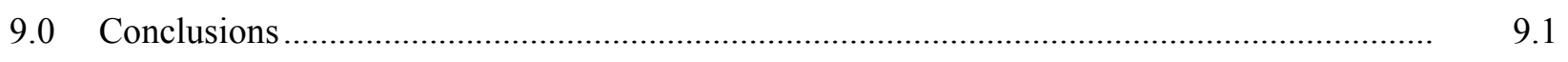

9.1 Slug-Test and Constant-Rate Pumping Test Results ............................................. 9.1

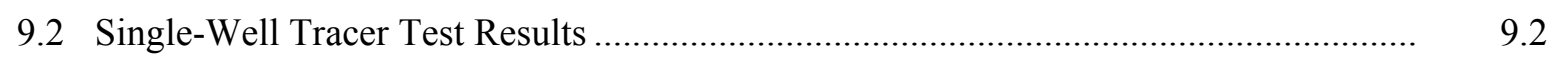

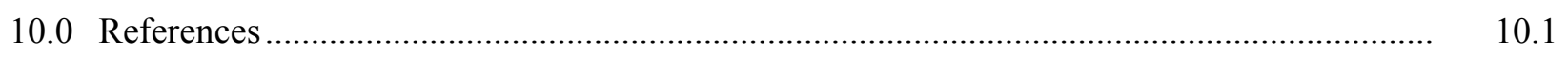

\section{Figures}

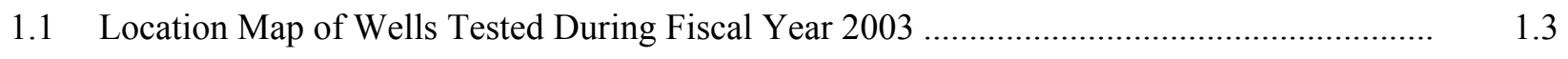

2.1 Stratigraphic Relationships of Various Hydrogeologic Units .......................................... 2.2

2.2 Hydrogeologic Cross Section Through 200-West and 200-East Areas ............................... 2.3

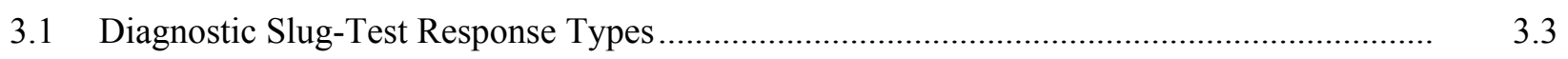

3.2 Predicted Slug-Test Response for Nonelastic Formation, Elastic Formation, and High Hydraulic Conductivity Sand-Pack Conditions ……........................................................ 3.6

3.3 Predicted Slug-Test Response: Negative Finite-Thickness Skin Conditions........................ 3.6 
3.4 Predicted Slug-Test Derivative Response: Negative Finite-Thickness Skin Conditions ........ 3.10

3.5 Predicted Slug-Test Response: Positive Finite-Thickness Skin Conditions ......................... 3.10

3.6 Effects of Hydraulic Conductivity on Predicted Under-Damped Slug-Test Response............ 3.12

3.7 Hypothetical Tracer-Dilution Pattern Indicative of Vertical In-Well Downward Flow .......... $\quad 3.17$

3.8 Characteristic Log-Log Drawdown and Drawdown Derivative Plots for Various Hydrogeologic Formation and Boundary Conditions .................................................... 3.21

4.1 Selected Slug-Test Analysis Plots for Well 299-E19-46 _..................................................

4.2 Selected Slug-Test Analysis Plots for Well 299-W26-14 ..................................................

4.3 High-K, Under-Damped Slug-Test Analysis Plot for Well 299-E24-22 …......................... 4.6

4.4 High-K, Critically-Damped Slug-Test Analysis Plot for Well 299-E25-93 _.......................

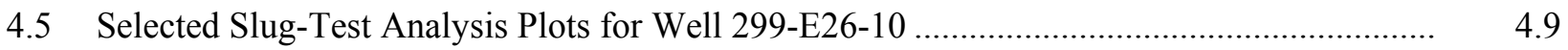

4.6 Selected Slug-Test Analysis Plots for Well 299-E26-11 „............................................... 4.11

4.7 High-K, Under-Damped Slug-Test Analysis Plot for Well 299-E27-23 ............................ 4.12

5.1 Tracer Concentration Versus Depth-Response Patterns Within Well 299-E26-10 During Tracer-Dilution Testing and Calculated In-Well Vertical Flow Velocity .............................. 5.2

5.2 Average Tracer-Dilution Test Results Within Well 299-E26-10 ...................................... 5.3

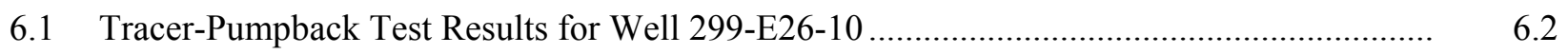

7.1 Diagnostic Plot Analysis of Drawdown Test Data for Pumping Well 299-E26-10 ................ 7.2

7.2 Straight-Line Analysis of Drawdown Test Data for Pumping Well 299-E26-10 .................. 7.3

7.3 Type-Curve and Derivative Plot Analysis of Drawdown Test Data for Pumping Well 299-E26-10.

8.1 Location Map for Well 299-E26-10 and Associated Monitor Well Sites Utilized in the Trend-Surface Analysis.

8.2 Dynamic Water-Level Elevation Plot for Selected Wells Utilized in the TrendSurface Analysis 


\section{Tables}

1.1 New and Recently Constructed RCRA Wells Characterized in Fiscal Year 2003 ................. 1.2

1.2 Pertinent As-Built Information for Wells Tested During Fiscal Year 2003 ............................

3.1 Detailed Hydrologic Characterization Elements ........................................................... 3.1

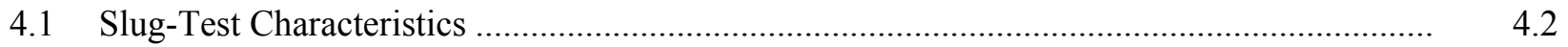

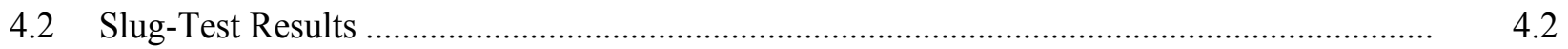

6.1 Tracer-Pumpback Test Summary for Well 299-E26-10 _......................................................

7.1 Constant-Rate Pumping Test Summary .....................................................................

8.1 Pertinent Information for Monitor Wells in LERF and Immediate Surrounding Area ............ $\quad 8.3$

8.2 Groundwater-Flow Characterization Results Based on Trend-Surface Analysis of All Monitor Well Water-Level Measurements in LERF and Immediate Surrounding Area .................... $\quad 8.4$

8.3 Groundwater-Flow Characterization Results Based on Trend-Surface Analysis of All Monitor Well Water-Level Measurements in LERF and Immediate Surrounding Area; Well 299-E34-7 Omitted

8.4 Groundwater-Flow Characterization Results Based on Trend-Surface Analysis of All Monitor Well Water-Level Measurements in LERF and Immediate Surrounding Area; Well 299-E26-11 Omitted

8.5 Groundwater-Flow Characterization Results Based on Trend-Surface Analysis of All Monitor Well Water-Level Measurements in LERF and Immediate Surrounding Area; Wells 299-E26-11 and-E34-7 Omitted 


\subsection{Introduction}

The Groundwater Performance Assessment Project managed by Pacific Northwest National Laboratory (PNNL) assesses the potential for onsite and offsite migration of contamination within the shallow, unconfined, aquifer system and the underlying, upper, basalt-confined aquifer system at the Hanford Site. As part of this activity, detailed hydrologic characterization tests are conducted within wells at selected Hanford Site locations to provide hydraulic property information and groundwater-flow characterization for the unconfined aquifer. Results obtained from these characterization tests provide hydrologic information that supports the needs of the Resource Conservation and Recovery Act (RCRA) facility hydrogeologic characterization and sitewide groundwater monitoring and modeling programs and reduces the uncertainty of groundwater-flow conditions at selected locations on the Hanford Site.

This report is the fifth of a series that provides the results of detailed hydrologic characterization tests conducted within new and recently constructed Hanford Site wells within the unconfined aquifer system. In the previous four reports, Spane et al. (2001a, 2001b, 2002, 2003) presented the results of hydrologic characterization tests conducted during FY 1999, 2000, 2001 and 2002, respectively. In this report, results of tests conducted during FY 2003 and/or extending into early FY 2004 are provided. The various characterization elements employed in FY 2003, as part of the detailed hydrologic characterization program, include the following:

- slug tests - to evaluate well-development conditions and provide preliminary hydraulic property information (e.g., hydraulic conductivity) for the design of subsequent hydrologic tests

- tracer-dilution tests - to determine the vertical distribution of hydraulic conductivity and/or groundwater-flow velocity within the well-screen section and to identify vertical flow conditions within the well column

- tracer-pumpback tests - to characterize effective porosity and average, aquifer, groundwater-flow velocity

- constant-rate pumping tests - to provide quantitative hydraulic property information (e.g., transmissivity, hydraulic conductivity, storativity, specific yield) when conducted in concert with tracerpumpback phase and analysis of drawdown and recovery data

- in-well vertical flow assessment - to determine in-well vertical flow conditions within the wellscreen section

- barometric response evaluation - to compare the characteristics of well response to barometric fluctuations, estimate vadose zone transmission characteristics, and remove barometric pressure effects from hydrologic test responses

- groundwater-flow characterization - to quantify the direction of groundwater flow and hydraulic gradient conditions 
Newly constructed and existing RCRA wells selected for characterization during FY 2003 are listed in Table 1.1. The RCRA wells are all constructed of 10.16-cm-diameter stainless-steel casing with wirewrapped stainless-steel screens and sand pack. These wells were constructed either to replace older wells that are going dry because of the declining water table (e.g., 200-West Area) or for additional monitoring well areal coverage. Most wells tested are screened across the water table and penetrate approximately the top 9 to $11 \mathrm{~m}$ of the aquifer. Two of the test wells (299-E26-10 and 299-E26-11) were selected to provide hydraulic characterization information within the Liquid Effluent Retention Facility (LERF). Well 299-E26-10 was selected for detailed hydrologic characterization. Figure 1.1 shows the location of the wells tested during FY 2003 in relationship to the 200-West and 200-East Areas of the Hanford Site. The alignment of the hydrogeologic cross-section discussed in Chapter 2.0 is also shown in the Figure. Boundaries of the various RCRA waste management areas are presented on site maps contained in Hartman et al. (2004). Table 1.2 provides pertinent as-built and well-completion information for the identified new wells. This report presents the results of hydrologic characterization conducted at these well sites during FY 2003.

Table 1.1. New and Recently Constructed RCRA Wells Characterized in Fiscal Year 2003

\begin{tabular}{||l|c||}
\hline \multicolumn{1}{|c|}{ Well } & $\begin{array}{c}\text { RCRA Waste Management Area and CERCLA } \\
\text { Groundwater Operable Units }\end{array}$ \\
\hline \hline $299-W 19-46$ & 200-UP-1 \\
\hline $299-W 26-14$ & S-10 Pond and Ditch \\
\hline $299-E 24-22$ & SST A-AX \\
\hline $299-E 25-93$ & SST A-AX \\
\hline $299-E 26-10$ & LERF \\
\hline 299-E26-11 & LERF \\
\hline 299-E27-23 & SST C \\
\hline SST = Single-shell tank. \\
\hline
\end{tabular}




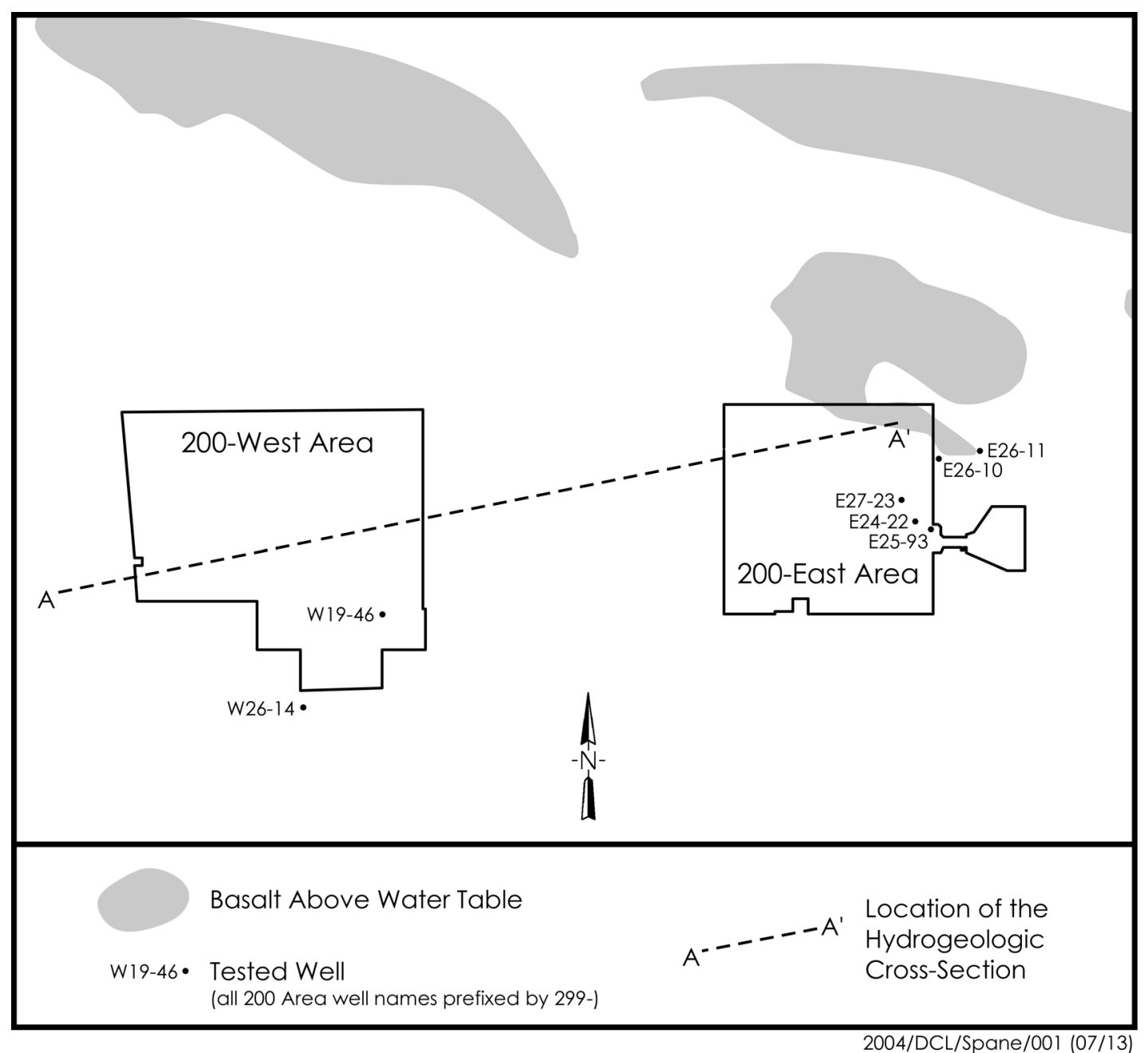

Figure 1.1. Location Map of Wells Tested During Fiscal Year 2003 
Table 1.2. Pertinent As-Built Information for Wells Tested During Fiscal Year 2003

\begin{tabular}{|c|c|c|c|}
\hline Well & $\begin{array}{c}\text { Ground Surface/Brass-Cap } \\
\text { Elevation, m, } \\
\text { MSL (NAVD88) }\end{array}$ & $\begin{array}{c}\text { Well-Screen Depth Below } \\
\text { Ground Surface/Brass } \\
\text { Cap, m }\end{array}$ & $\begin{array}{l}\text { Saturated Well-Screen } \\
\text { Section, m } \\
\text { MSL (NAVD88) }\end{array}$ \\
\hline 299-W19-46 & 213.39 & $77.72-88.39$ & $\begin{array}{c}135.04-125.00 \\
(10.04)^{(a)}\end{array}$ \\
\hline 299-W26-14 & 205.43 & $68.08-78.75$ & $\begin{array}{c}137.09-126.68 \\
(10.41)\end{array}$ \\
\hline 299-E24-22 & 209.55 & $87.24-97.92$ & $\begin{array}{c}122.27-111.63 \\
(10.64)\end{array}$ \\
\hline 299-E25-93 & 207.27 & $84.80-95.48$ & $\begin{array}{c}122.25-111.79 \\
(10.46)\end{array}$ \\
\hline 299-E26-10 & 183.51 & $58.37-63.13$ & $\begin{array}{c}122.36-120.38 \\
(1.98)\end{array}$ \\
\hline 299-E26-11 & 182.98 & $61.25-62.95$ & $\begin{array}{c}121.73-120.03^{(\mathrm{b})} \\
(1.70)\end{array}$ \\
\hline 299-E27-23 & 205.66 & $83.37-94.04$ & $\begin{array}{c}122.29-111.62 \\
(10.67)\end{array}$ \\
\hline \multicolumn{4}{|c|}{$\begin{array}{l}\text { (a) Number in parentheses is saturated thickness within the well-screen interval; it reflects conditions } \\
\text { at time of slug testing. } \\
\text { (b) Water table is located } 1.56 \mathrm{~m} \text { above top of well screen. } \\
\text { MSL = mean sea level. } \\
\text { NAVD88 = North American Vertical Datum of } 1988 \text {. }\end{array}$} \\
\hline
\end{tabular}




\subsection{Hydrogeologic Setting}

Major hydrogeologic units within the sediments above the basalt bedrock in the 200-West and 200-East Areas include the Ringold Formation and the overlying, informally named, Hanford formation. The less extensive Cold Creek Unit occurs between these formations in some places. Lindsey (1995) has stratigraphically divided the Ringold Formation into different facies associations based on geologic characteristics and depositional environment. The facies classifications and depositional environments of post-Ringold sediments, including the Cold Creek Unit and the Hanford formation, are discussed in DOE (2002). In addition to this geologic classification system, a hydrogeologic-based classification system was developed (Thorne et al. 1993; Cole et al. 2001) to support consolidated groundwater-modeling studies of the Hanford Site. This system is also based on the Ringold facies classification of Lindsey (1995), but subdivides units based on texture with less emphasis on the time of deposition. A comparison of the two classifications is shown in Figure 2.1. The major classification system difference in the vicinity of the 200 Areas is the grouping of the lower sand-dominated portion of Lindsey's (1995) upper Ringold with Ringold gravel Units $\mathrm{E}$ and $\mathrm{C}$ to form hydrogeologic model Unit 5. A general west-to-east cross section in Figure 2.2 shows the hydrogeologic units underlying the 200-West and 200-East Areas. Figure 1.1 shows the surface trace of the cross section in relationship to the test wells described in this report.

The brief hydrogeologic description for the 200-West and 200-East Areas presented below is taken primarily from Spane et al. (2003), which is based on the following reports: Graham et al. (1984), Lindsey et al. (1992), Connelly et al. (1992a, 1992b), Thorne et al. (1993), Lindsey (1995), and Williams et al. (2000).

\subsection{Hydrogeology of the 200-West Area}

The aquifer system above the basalt bedrock in the 200-West Area comprises two aquifer systems: an unconfined aquifer and an underlying, locally confined aquifer. The unconfined aquifer lies almost entirely within the Ringold Unit E gravel (Unit 5) and is composed of fluvial, gravel-dominated sediments with a fine-sand matrix. The FY 2003 results for test wells located in 200-West Area reflect the Ringold Unit E gravel (Unit 5). Sediment within this hydrogeologic unit exhibits variable degrees of cementation, ranging from partially to well-developed. Cemented zones up to several meters thick and extending laterally over several hundred meters have been identified in 200-West Area. Thin, laterally discontinuous, sand and silt beds also are intercalated in the gravelly deposits.

The lower Ringold mud (Unit 8), consisting of overbank and lacustrine deposits, underlies the unconfined aquifer. This mud unit is continuous over the entire 200-West Area but is absent just north of 200-West Area. The lower mud unit generally thickens and dips to the south and southwest. The top of the mud unit, which has an irregular surface, forms the lower boundary of the unconfined aquifer in 200-West Area.

The lower mud separates the unconfined aquifer from an underlying confined aquifer, which is composed of the Ringold Unit A gravel (Unit 9). This unit is composed of fluvial gravels with lesser 


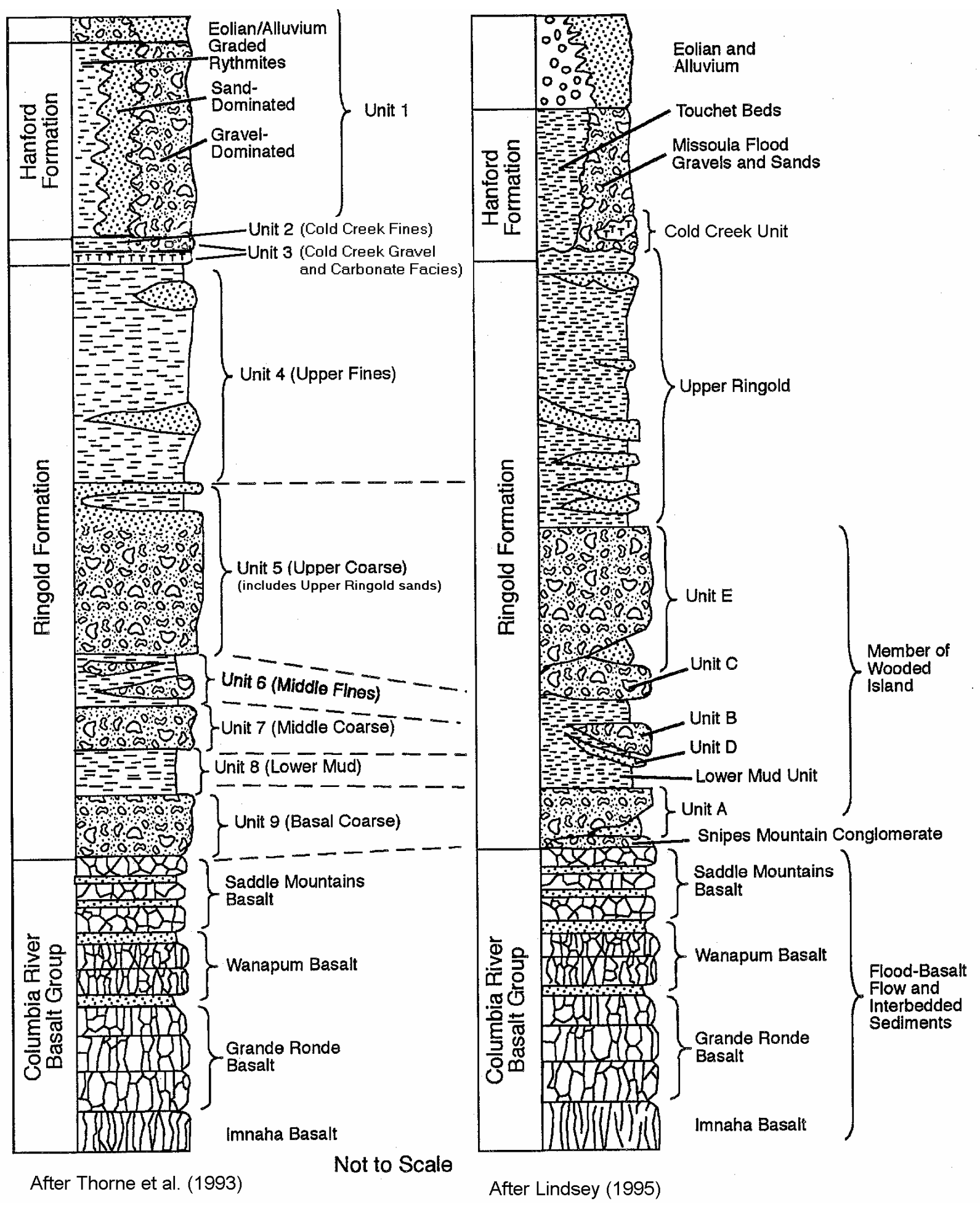

Figure 2.1. Stratigraphic Relationships of Various Hydrogeologic Units 


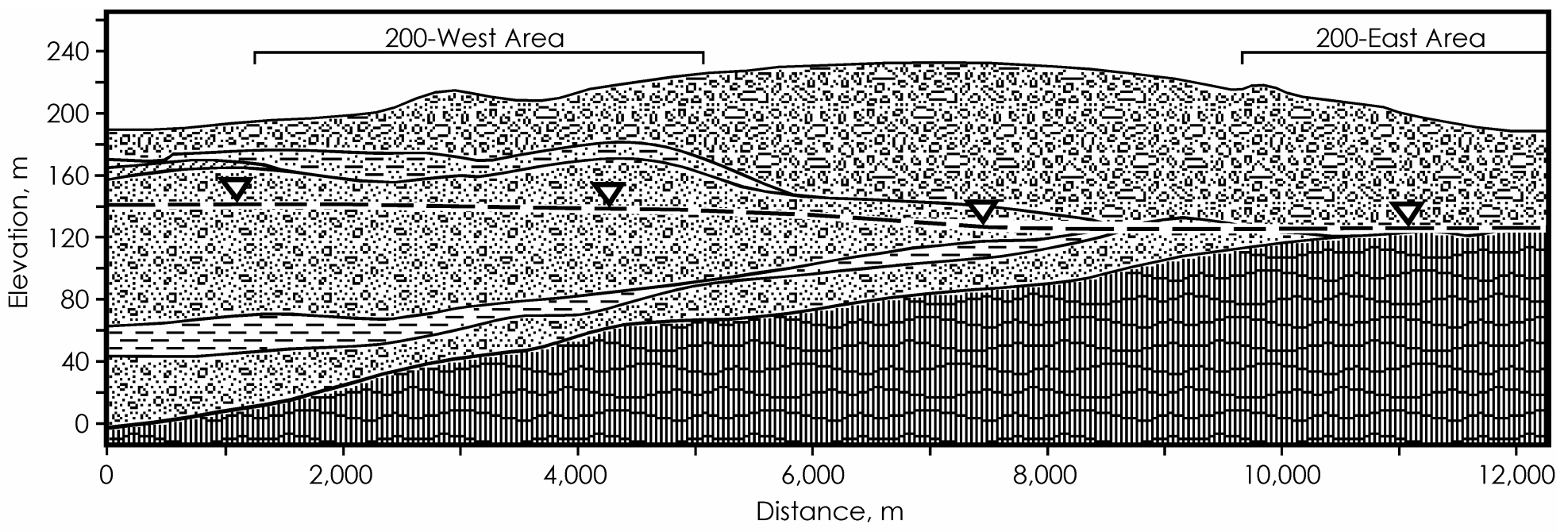

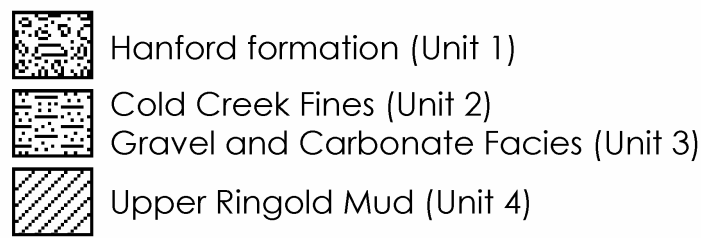

$--\underline{\nabla}-1998$ Water Table

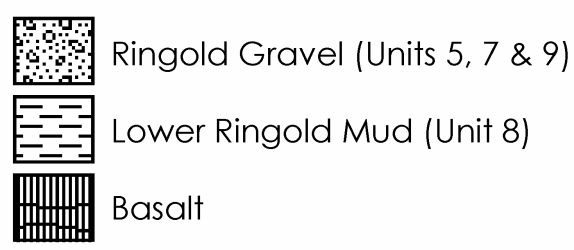

2004/DCL/Spane/002 (07/27)

Figure 2.2. Hydrogeologic Cross Section Through 200-West and 200-East Areas (modified from Spane et al. 2003) 
amounts of intercalated sands and silts. This basal unit, which lies directly above the basalt bedrock, thickens and dips to the south and southwest. The uppermost basalt formation beneath 200-West Area is the Saddle Mountains Basalt.

\subsection{Hydrogeology of the 200-East Area}

As in the 200-West Area, the aquifer system above the basalt in the 200-East Area consists of the unconfined aquifer and, in some places, a locally confined aquifer that underlies the discontinuous lower Ringold mud (Unit 8). The unconfined aquifer within the 200-East Area lies within the Hanford formation (Unit 1) and/or Ringold Formation gravel units E, C, and A (Units 5, 7, and 9) (see Figure 2.1). In the northern part of 200-East Area, the unconfined aquifer is thin in locations where the basalt surface forms subsurface highs. In these locations, the unconfined aquifer lies almost entirely within the Hanford formation (Unit 1). Most wells recently tested within 200-East Area (Spane et al. 2001a, 2001b, 2002, 2003) are reflective of either the Hanford formation or reworked Ringold gravel Unit E sediments. Some or all of these undifferentiated gravel- and sand-dominated sediments may represent reworking of the Ringold Formation deposits by either ancestral Columbia River or Missoula flood events, which removed fine-grained material, decreased consolidation, and increased permeability of the sediments. Because of the preponderance of unconsolidated gravel and sand deposits, this unit generally exhibits higher permeabilities than older, non-reworked hydrogeologic units within the Ringold Formation.

The lower boundary of the unconfined aquifer in 200-East Area is defined by the top of the lower Ringold mud (Unit 8), top of a fine-grained subunit within Ringold gravel unit A (Unit 9B), or top of relatively impermeable basalt. However, the basalt flow top associated with the uppermost basalt flow may be brecciated and form part of the unconfined aquifer. To the north of 200-East Area, the lower Ringold Formation units and underlying upper basalt flows were extensively eroded by the Missoula floods at the time the Hanford formation was deposited. Previous reports have indicated that direct hydrogeologic communication between the unconfined and underlying, upper, basalt-confined aquifer is likely in these areas (Gephart et al. 1979; Graham et al. 1984; Spane and Webber 1995).

The Ringold lower mud (Unit 8), which forms the confining mud unit separating the overlying, unconfined aquifer from the underlying, locally confined, aquifer within Ringold gravel unit A (Unit 9), is composed primarily of low-permeability, fluvial overbank, paleosol, and lacustrine silts and clay, with minor amounts of sand and gravel. As indicated in Figure 2.1, Ringold gravel unit A (Unit 9) is composed of local subunits. Unit 9B consists of poorly characterized silt- to clay-rich zones and represents a relatively thin, low-permeability, local confining unit within the basal Ringold gravel. East of the 200-East Area near the 216-B-3 Pond, confining Units 8 and 9B extend above the regional water table. 


\subsection{Detailed Test Characterization Methods}

This report provides the results of detailed hydrologic characterization tests conducted within selected Hanford Site wells during FY 2003. Detailed characterization tests performed included groundwater-flow characterization, barometric response evaluation, slug tests, single-well tracer tests (tracer-dilution, tracerpumpback, and in-well vertical flow tests), and constant-rate pumping tests.

Table 3.1 provides a summary of the various hydrologic characterization elements. More in-depth descriptions of the methods used to analyze slug tests, various single-well tracer tests, and constant-rate pumping tests are provided in the following sections and are taken primarily from Spane et al. (2002 and 2003).

\subsection{Slug Tests}

A slug test involves the instantaneous injection or withdrawal of a known volume of water directly to the water column within the well, and monitoring the associated recovery response back to pre-test, static level conditions. Because of their ease of implementation and relatively short duration, slug tests are commonly used to provide initial estimates of hydraulic properties (e.g., range and spatial/vertical distribution of hydraulic conductivity, K). Because of the small displacement volumes employed during

Table 3.1. Detailed Hydrologic Characterization Elements

\begin{tabular}{||l|l|l||}
\hline \multicolumn{1}{|c|}{ Element } & \multicolumn{1}{|c||}{ Activities } & \multicolumn{1}{c||}{ Results $^{\text {(a) }}$} \\
\hline \hline $\begin{array}{l}\text { Groundwater-flow } \\
\text { characterization }\end{array}$ & $\begin{array}{l}\text { Trend-surface analysis of well } \\
\text { water-level data }\end{array}$ & $\begin{array}{l}\text { Quantitative determination of groundwater-flow } \\
\text { direction and hydraulic gradient }\end{array}$ \\
\hline $\begin{array}{l}\text { Barometric response } \\
\text { evaluation }\end{array}$ & $\begin{array}{l}\text { Well water-level response } \\
\text { characteristics to barometric } \\
\text { changes }\end{array}$ & $\begin{array}{l}\text { Aquifer-/well-model identification, vadose zone } \\
\text { property characterization, correction of hydrologic } \\
\text { test responses for barometric pressure fluctuations }\end{array}$ \\
\hline Slug test & $\begin{array}{l}\text { Multistress-level tests conducted } \\
\text { at each well site }\end{array}$ & Local $\mathrm{K}_{\mathrm{h}}, \mathrm{T}$ of aquifer surrounding well site \\
\hline Tracer-dilution test & $\begin{array}{l}\text { Monitoring dilution of admin- } \\
\text { istered tracer at injection well site }\end{array}$ & Determination of $\mathrm{v}_{\mathrm{w}}$ and vertical distribution of $\mathrm{K}_{\mathrm{h}}$ \\
\hline Tracer-pumpback test & $\begin{array}{l}\text { Pumping/monitoring of } \\
\text { recovered tracer and associated } \\
\text { pressure response in monitor } \\
\text { wells }\end{array}$ & Local- to intermediate-scale $\mathrm{n}_{\mathrm{e}}$ and $\mathrm{v}_{\mathrm{a}}$ \\
\hline In-well vertical tracer test & $\begin{array}{l}\text { Monitoring the vertical move- } \\
\text { ment of tracer within the well } \\
\text { screen }\end{array}$ & $\begin{array}{l}\text { Determination of } \mathrm{v}_{\mathrm{w}} \text { within the monitor well-screen } \\
\text { section }\end{array}$ \\
\hline Constant-rate pumping test & $\begin{array}{l}\text { Pumping/monitoring of pressure } \\
\text { response in monitor wells }\end{array}$ & $\begin{array}{l}\text { Intermediate to large-scale, } \mathrm{K}_{\mathrm{h}}, \mathrm{K}_{\mathrm{v}} / \mathrm{K}_{\mathrm{h}}, \mathrm{K}_{\mathrm{hx}} / \mathrm{K}_{\mathrm{hy}}, \mathrm{T}, \mathrm{S}, \\
\mathrm{S}_{\mathrm{y}}\end{array}$ \\
\hline \hline
\end{tabular}


slug tests, hydraulic properties determined using this characterization method are representative of conditions relatively close to the well. For this reason, slug-test results are commonly used to design subsequent hydrologic tests having greater areas of investigation (e.g., slug interference [Novakowski 1989; Spane 1996; Spane et al. 1996], constant-rate pumping tests [Butler 1990; Spane 1993]).

Slug tests conducted as part of the FY 2003 detailed characterization program were performed by removing a slugging rod (withdrawal test) of known displacement volume. Slug-withdrawal tests were employed rather than slug-injection tests (i.e., by rapidly immersing the slugging rod) because of their reported superior results for unconfined aquifer tests where the water table occurs within the well-screen section (e.g., Bouwer 1989). At all test sites, two different size slugging rods were used to impart varying stress levels for individual slug tests. The slug tests were repeated at each stress level to assess reproducibility of the test results. Comparison of the normalized slug-test responses is also useful to evaluate stress-dependent, non-linear test well conditions. Evidence of stress dependence for tests within low to intermediate permeability formations, may indicate the effectiveness of well development, and the presence of near-well heterogeneities and dynamic skin conditions, as noted in Butler et al. (1996). Dynamic skin conditions refer to the non-repeatability of test responses conducted at a particular stress level. This non-repeatability of test response is commonly associated with changing formational conditions near the well caused by incomplete well development. As described in Butler (1997), hydraulic property characterization results obtained from wells exhibiting stress dependence should be viewed with caution; with more credence given to test responses exhibiting less lagged response characteristics (e.g., tests conducted at lower stress levels). Conversely, wells exhibiting repeatable slug test response at different stress levels indicate a stable or static formation condition surrounding the well, and suggest that well has been effectively developed.

Based on volumetric relationships, the two different size slugging rods theoretically impart a slug-test stress level of $0.458 \mathrm{~m}$ (low-stress tests) and $1.117 \mathrm{~m}$ (high-stress tests) within a 0.1016-m inside diameter well. However, for conditions where wells are screened across the water table, as for most of the Hanford Site wells tested in FY 2003 and where the well-screen sand pack has a relatively high permeability, the actual stress level imposed on the test formation may be lower than the theoretical stress level. This is due to the added pore volume of the sand pack at the time of test initiation. For these situations, the actual slug-test stress level is determined by projecting the observed early test response back to the time of test initiation. For situations where the theoretical slug-test stress level, $\mathrm{H}_{\mathrm{o}}$, is greater than the observed or projected stress level, $\mathrm{H}_{\mathrm{p}}$, an equivalent well radius, $\mathrm{r}_{\mathrm{eq}}$, must be used instead of the actual well-casing radius, $r_{c}$, in the various analytical methods. The $r_{\text {eq }}$ can be calculated by using the following relationship presented in Butler (1997):

$$
r_{e q}=r_{c}\left(H_{o} / H_{p}\right)^{1 / 2}
$$

The previous discussion is particularly relevant and applicable for tests performed within formations possessing low to intermediate permeabilities. For test formations exhibiting very high permeabilities (e.g., $>50 \mathrm{~m} / \mathrm{d}$ ), this relationship may not be utilized due to the uncertainty of actual applied stress, $\mathrm{H}_{0}$. The uncertainty occurs due to the finite time required for slugging rod removal (i.e., $\sim 1$ second) and the associated test recovery that occurs during the removal process. For high-permeability test formation situations, the observed maximum $\mathrm{H}_{\mathrm{o}}$ is commonly used and $\mathrm{r}_{\mathrm{eq}}$ assumed to be equal to $\mathrm{r}_{\mathrm{c}}$. 
As discussed in Butler (1997), water levels within a well can respond in one of three ways to the instantaneously applied stress of a slug test. As shown in Figure 3.1, these response model patterns are: (1) an over-damped response, where the water levels recover in an exponentially decreasing recovery pattern; (2) an underdamped response, where the slug test response oscillates above and below the initial static, with decreasing peak amplitudes with time; and (3) critically damped, where the slug test behavior

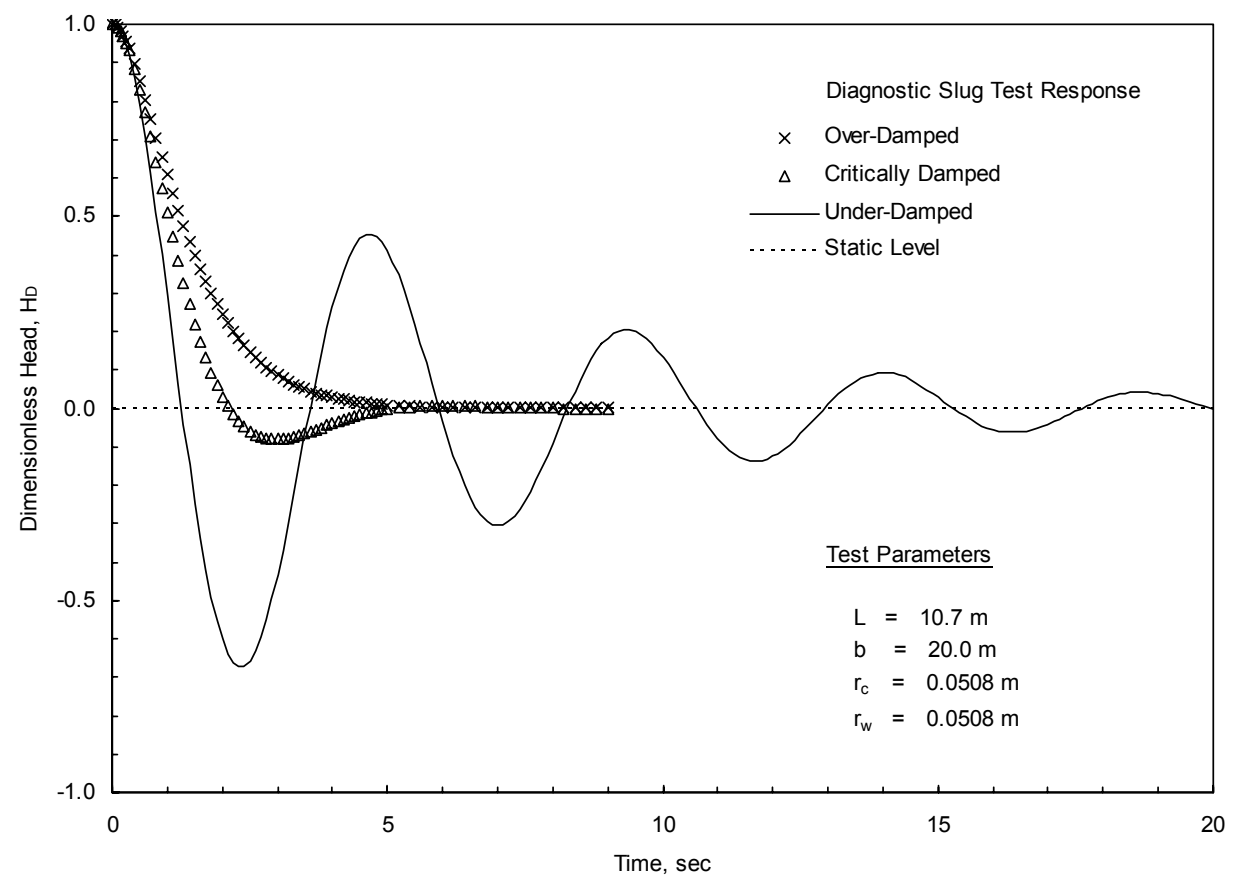

Figure 3.1. Diagnostic Slug-Test Response Types

exhibits characteristics that are transitional to the over- and under-damped response patterns. Factors that control the type of slug test response model exhibited within a well include a number of aquifer properties (hydraulic conductivity) and well dimension characteristics (well-screen length, well-casing radius, wellradius, fluid-column length) and can be expressed by the response damping parameter, $\mathrm{C}_{\mathrm{D}}$, which Butler (1997) reports for unconfined aquifer tests as:

$$
C_{D}=\left(\mathrm{g} / \mathrm{L}_{\mathrm{e}}\right)^{1 / 2} r_{c}^{2} \ln \left(R_{e} / r_{w}\right) /(2 K L)
$$

where $\mathrm{g}=$ acceleration due to gravity

$\mathrm{L}_{\mathrm{e}}=$ effective well water-column length

$r_{c}=$ well casing radius; i.e., radius of well water-column that is active during testing

$\mathrm{R}_{\mathrm{e}}=$ effective test radius parameter; as defined by Bouwer and Rice (1976)

$\mathrm{r}_{\mathrm{w}}=$ well radius

$\mathrm{K}=$ hydraulic conductivity of test interval

$\mathrm{L}=$ well-screen length 
Given the multitude of possible combinations of aquifer properties, well casing dimensions, and test interval lengths, no universal $\mathrm{C}_{\mathrm{D}}$ value ranges can be provided that describe slug test response conditions. However, in considering various test site conditions that might be encountered at newly constructed Hanford Site RCRA monitoring wells (i.e., with a saturated well-screen length, $\mathrm{L}=10.67 \mathrm{~m}$ and well casing radius, $r_{c}=0.051 \mathrm{~m}$ ), the following general guidelines on slug test response prediction are provided:

- $\mathrm{K} \leq 27 \mathrm{~m} /$ day: $\quad \mathrm{C}_{\mathrm{D}}>2=$ over-damped response

- $\mathrm{K}=27$ - $54 \mathrm{~m} /$ day: $\mathrm{C}_{\mathrm{D}} 1-2$ = critically-damped response

- $\mathrm{K} \geq 54 \mathrm{~m} /$ day: $\quad \mathrm{C}_{\mathrm{D}}<1=$ under-damped response

Over-damped test response generally occurs within test wells monitoring low to moderately high permeability formations (e.g., Ringold Formation), and are indicative of test conditions where frictional forces (i.e., resistance of groundwater flow from the test interval to the well) are predominant over test system inertial forces. For over-damped slug tests, two different methods were used for the slug-test analysis: the semiempirical, straight-line analysis method described in Bouwer and Rice (1976) and Bouwer (1989) and the type-curve-matching method for unconfined aquifers presented in Butler (1997). A detailed description of over-damped slug-test analysis methods is presented in following Section 3.1.1. Analysis details and results of slug tests exhibiting over-damped response characteristics at monitor wells tested during FY 2003 are provided in Chapter 4.0.

Under-damped test response patterns are exhibited within stress wells where inertial forces are predominant over formation frictional forces. This commonly occurs in wells with extremely long well fluid columns (i.e., large water mass within the well column) and/or that penetrate highly permeable aquifers (e.g., Hanford formation). Tests exhibiting under-damped behavior should be conducted with very small stress levels, i.e., $\mathrm{H}_{\mathrm{o}}<<\mathrm{L}$, as originally noted in Van der Kamp (1976) and restated in Butler (1997). For standard Hanford Site RCRA wells exhibiting under-damped test conditions, the maximum stress level utilized for such test sites should not generally exceed $\sim 1 / 10$ of the saturated well-screen length. Methods for analyzing unconfined aquifer tests exhibiting high permeability under-, over- or critically damped characteristics include techniques described in Springer and Gelhar (1991), Butler (1997), McElwee and Zenner (1998), Butler and Garnett (2000), Zurbuchen et al. (2002), and Butler et al. (2003). Because of the ease provided by a spreadsheet-based approach, the analysis method presented in Butler and Garnett (2000) was used for the analysis of all tests exhibiting under-damped response behavior (i.e., high permeability/oscillatory pattern). A detailed description of under-damped slug-test analysis methods is presented in following Section 3.1.2. Analysis details and results of slug tests exhibiting over-damped response characteristics at monitor wells conducted during FY 2003 are provided in Chapter 4.0.

Critically damped test responses are indicated by stress well water-level responses that are transitional to the over- and under-damped test conditions, as shown in Figure 3.1. They typically occur in wells that monitor test formations exhibiting relatively high hydraulic conductivity. As noted in Butler (1997), distinguishing between critically and over-damped slug test response may be difficult in some cases (i.e., due to test signal noise) when examined on arithmetic plots. Proper model identification may be enhanced, however, when semi-log plots are utilized, i.e., log head versus time. Critically damped slug 
tests exhibit a diagnostic concave-downward pattern when plotted in semi-log plot format. This is in contrast to over-damped response behavior, which displays either a linear or concave upward pattern. Slug tests exhibiting critically damped test response can be analyzed with the same analytical methods used for under-damped tests. Generally, the analysis method presented in Butler and Garnett (2000) was used for all tests exhibiting critically-damped response behavior.

\subsubsection{Over-Damped Test Analysis Methods}

The following sections provide a detailed discussion of analytical methods and considerations for slug tests exhibiting over-damped responses.

\subsubsection{Bouwer and Rice Method}

The Bouwer and Rice method is a well-known technique and is widely applied in the analysis of slug tests. A number of analytical weaknesses, however, limit the successful application of the Bouwer and Rice method for analyzing slug-test response. These weaknesses constrain its application to slug-test responses that exhibit steady-state flow, isotropic conditions, no well-skin effects, and no elastic (storage) formation response. Unfortunately, these limitations are commonly ignored, and the Bouwer and Rice method is applied to slug-test responses that do not meet the test analysis criteria. A more detailed discussion on the analytical limitations of the Bouwer and Rice method is provided in Hyder and Butler (1995), Brown et al. (1995), and Bouwer (1996).

For slug tests exhibiting elastic storage response, it should be noted that improved estimates can be obtained if analysis criteria specified in Butler $(1996,1997)$ are observed. Figure 3.2 shows the predicted, normalized, slug-test response for three well/aquifer-test conditions: (1) nonelastic formation, (2) elastic formation, and (3) elastic formation with high-K sandpack effects. The test responses were calculated using the Kansas Geological Survey (KGS) model described in Liu and Butler (1995) for the given test conditions listed in Figure 3.2. As shown, the presence of elastic aquifer storage (i.e., specific storage, $\mathrm{S}_{\mathrm{s}}$ ) and effects of a high-permeability sand pack cause curvilinear test responses (concave upward) that deviate from the predicted linear, nonelastic formation response. When this diagnostic curvilinear response is exhibited in the slug-test response, Butler $(1996,1998)$ recommends that the late-time test analysis be employed (i.e., the normalized head segment between 0.3 and 0.2) when using the Bouwer and Rice (1976) method. As shown in Figure 3.3, the two elastic curvilinear test responses over the specified latetime segment closely parallel the nonelastic test-formation response. This indicates that quantitative estimates for $\mathrm{K}$ can be obtained using the Bouwer and Rice method over a wide range of test-response conditions (nonelastic or elastic formation, high-K sandpack effects), if the proper analysis criteria are applied.

Because of its semi-empirical nature, analytical results obtained using the Bouwer and Rice method (i.e., in contrast to results obtained using the type-curve-matching method) may be subject to error. Bouwer and Rice (1976) indicated that the K estimate, using their analysis method, should be accurate to within $10 \%$ to $25 \%$. Hyder and Butler (1995) state an accuracy level for the Bouwer and Rice method within $30 \%$ of actual for homogeneous, isotropic formations, with decreasing levels of accuracy for more complex well/aquifer conditions (e.g., well-skin effects). For these reasons, greater credence is generally afforded the analytical results obtained using the type-curve-matching approach, which has a more rigorous analytical basis. 


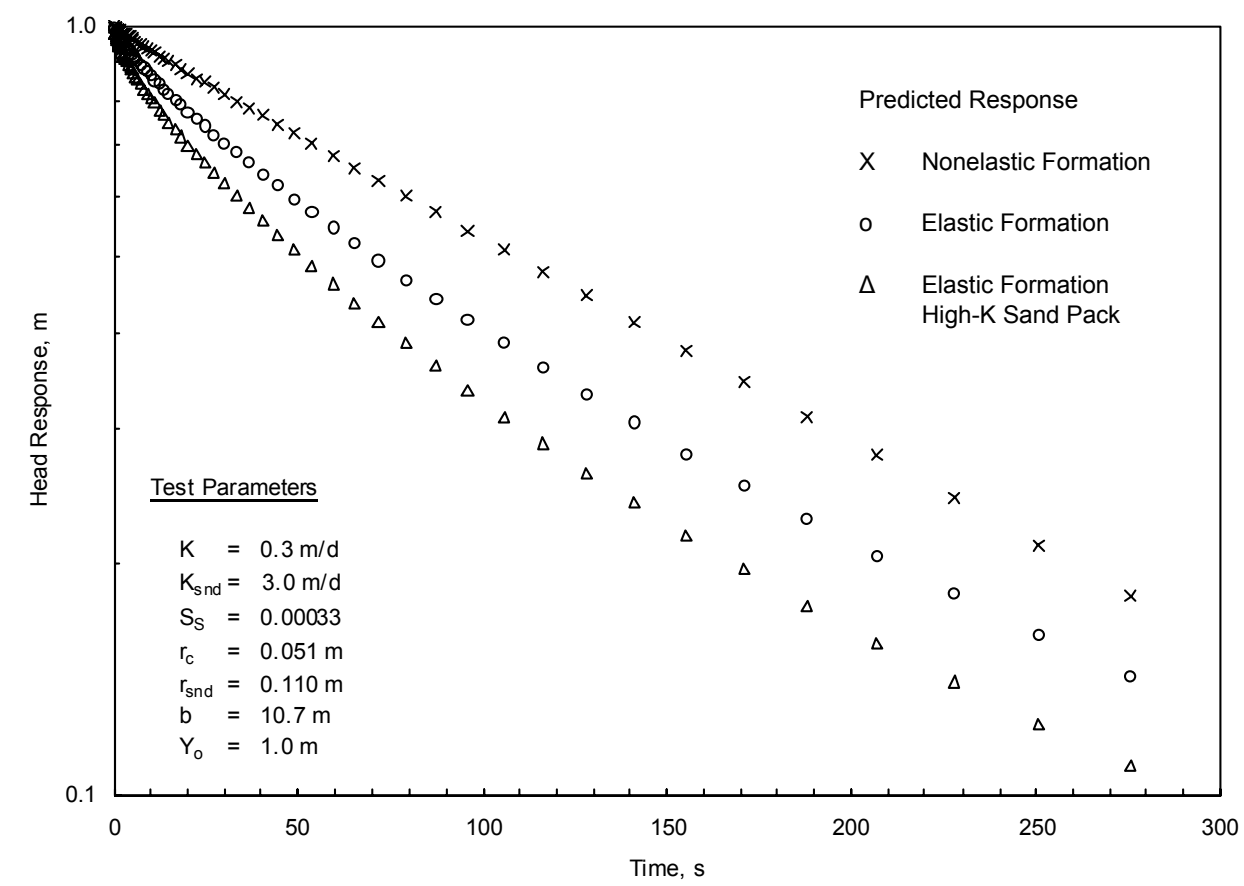

Figure 3.2. Predicted Slug-Test Response for Nonelastic Formation, Elastic Formation, and High Hydraulic Conductivity Sand-Pack Conditions

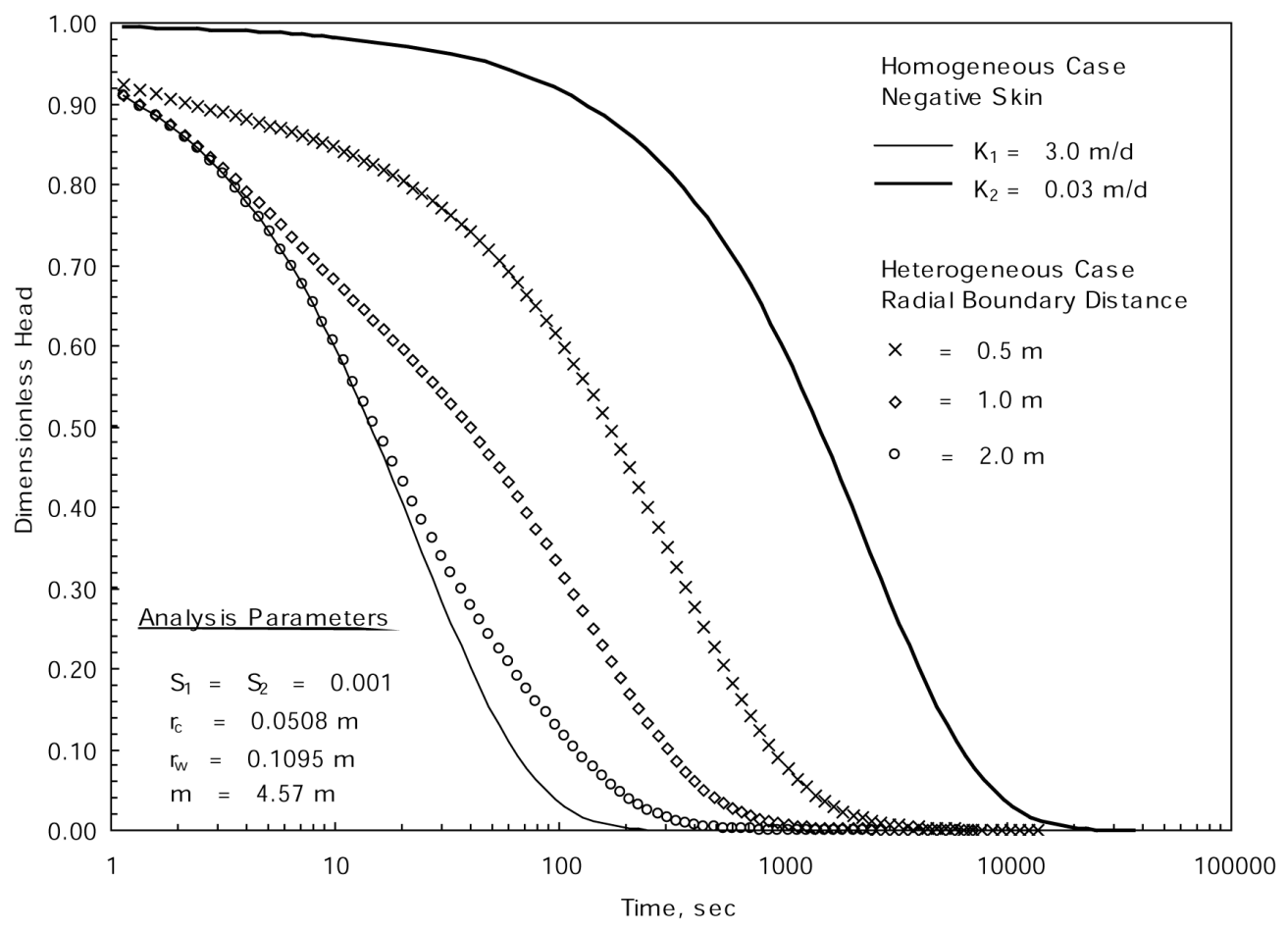

Figure 3.3. Predicted Slug-Test Response: Negative Finite-Thickness Skin Conditions 


\subsubsection{Type-Curve Method}

Because the type-curve method can use all or any part of the slug-test response in the analysis procedure, it is particularly useful for analyzing unconfined aquifer tests. The method also does not have any of the aforementioned analytical weaknesses of the Bouwer and Rice method. To facilitate the standardization of the slug-test type-curve analyses, a set of initial analysis parameters was assumed:

- a vertical anisotropy, $\mathrm{K}_{\mathrm{D}}$, value of 1

- a specific storage, $\mathrm{S}_{\mathrm{s}}$, value of $0.00001 \mathrm{~m}^{-1}$

- the well-screen interval below the water table was assumed to be equivalent to the test-interval section

To standardize the slug-test type-curve-matching analysis for all slug-test responses, a $1 \mathrm{~K}_{\mathrm{D}}$ was assumed. As noted in Butler (1997), this is the recommended value to use for slug-test analysis when setting the aquifer thickness to the well-screen length. Previous investigations by F. A. Spane (author) have indicated that single-well slug-test responses are relatively insensitive to $\mathrm{K}_{\mathrm{D}}$; therefore, the use of an assumed (constant) value of 1 over a small well-screen section (i.e., $\leq 10 \mathrm{~m}$ long) is not expected to have a significant impact on the determination of hydraulic conductivity, $K_{h}$, from the type-curve-matching analysis.

To facilitate the unconfined aquifer slug-test type-curve analysis, an $\mathrm{S}_{\mathrm{s}}$ value of $0.00001 \mathrm{~m}^{-1}$ was used for all initial analysis runs. After initial matches were made through adjustments of transmissivity, $\mathrm{T}$, additional adjustments of $S_{s}$ were then attempted to improve the overall match of the test-response pattern. In most test cases, slight modifications (i.e., increasing $S_{s}$ ) were made to the input $S_{\mathrm{s}}$ values to improve the final analysis type-curve matches. However, other factors influence the shape of the slug-test curve (e.g., skin effects, $\mathrm{K}_{\mathrm{D}}$ ). For this reason, the $\mathrm{S}_{\mathrm{s}}$ estimate obtained from the final slug-test analyses is considered to be of only qualitative value and should not be used (as in the case for $K_{h}$ ) for quantitative applications.

For the slug-test analysis, the well-screen interval below the water table (rather than the sandpack interval) was used to represent the test interval. This was based on the assumption that formation materials within the screened interval have a higher permeability than the sandpack; therefore, testresponse transmission is expected to propagate faster laterally from the well screen to the surrounding test formation than vertically within the sandpack zone. In reality, only small differences exist between individual well-screen and sandpack-interval lengths (i.e., compared to the aquifer-thickness relationship) and, subsequently, no significant differences in analysis results would be expected. This assumption is consistent with recommendations listed in Butler (1996).

The type-curves analyses presented in this report were generated using the KGS program described in Liu and Butler (1995). The KGS program is not strictly valid for the boundary condition, where the water table occurs within the well screen. However, a comparison of slug-test type curves generated from converted pumping test type curves (as described in Spane 1996), which accounts for this boundary effect, indicates very little difference in predicted responses when compared to the KGS model results. 
Because of this close comparison and the fact that the KGS program calculates slug-test responses directly and can be applied more readily for analysis of the slug-test results, it was used as the primary type-curve-analysis method in this report.

\subsubsection{Heterogeneous Formation Analysis}

Inherent in the analytical methods discussed above is the assumption that the test interval is homogeneous. A number of formation heterogeneities, however, can exert significant influence on slug-test response. Recognized heterogeneous formation conditions affecting slug-test response include multilayers of varying hydraulic properties within the well-screen section, presence of linear boundaries, and radial variation of hydraulic properties with distance from the well (i.e., radial boundaries).

The effects of multi-layer conditions within the test interval have been examined previously by Butler et al. (1994) and Butler (1997). These studies indicate that the presence of multi-layers of varying hydraulic properties cannot be distinguished from the pattern of the slug-test response. For well screens that fully penetrate a heterogeneous, multi-layer aquifer, the hydraulic conductivity estimated from the slug test will be an arithmetic average of the thickness-weighted $\mathrm{K}_{\mathrm{h}}$ values of the individual layers. For well screens that partially penetrate the upper-part of a multi-layer aquifer, the hydraulic conductivity estimated from the test also will represent a thickness-weighted arithmetic average, as long as significant vertical leakage does not occur from layers underlying the test interval.

The effects of linear boundaries on slug-test response have been examined previously by Karasaki et al. (1988) and Guyonnet et al. (1993). These effects are largely dependent on the nature of the boundary (i.e., no-flow or constant-head), proximity to the test well, and the storage characteristics of the aquifer and well. As a generalization, Guyonnet et al. (1993) state that no-flow boundaries cause the slug-test response to deviate from and delay recovery, while constant-head boundaries cause the slug test to recover faster than that predicted for a corresponding unbounded system response. Karasaki et al. (1988) accounts for the presence of linear boundaries within slug-test response by employing image-well theory. The effect of linear boundaries is very similar to that imposed by radial boundaries, which is discussed in the following paragraphs.

The effects of radial variations of hydraulic properties surrounding the test well have been investigated previously in studies examining slug tests in the presence of finite-thickness skin (e.g., Moench and Hsieh 1985). A finite-thickness skin is essentially a radial boundary condition surrounding a fullypenetrating well, where the inner zone has significantly different hydraulic properties than the outside zone. A negative skin refers to the case where $\mathrm{K}_{\mathrm{h}}$ of the inner zone is much greater than that of the outer zone (i.e., $\mathrm{K}_{1}>>\mathrm{K}_{2}$ ); while a positive skin denotes the opposite condition (i.e., $\mathrm{K}_{1}<<\mathrm{K}_{2}$ ). The effects of a radial boundary on slug-test response are largely a function of the contrast in $\mathrm{K}_{\mathrm{h}}$ for the inner and outer zone, the storage characteristics, and radial distance from the well to the boundary.

Figure 3.3 shows the predicted slug-test responses for a negative finite-thickness skin condition, where the inner zone has a $\mathrm{K}_{\mathrm{h}} 100$ times greater than the outer zone, for various selected radial boundary distances $(0.5,1,2 \mathrm{~m})$. The test responses were generated using the KGS program referenced in Section 3.1.2, which can account for finite-thickness well-skin conditions. For comparison purposes, homogeneous slug-test responses (i.e., no radial boundary) for the $\mathrm{K}_{\mathrm{h}}$ representative solely of the inner 
and outer zones also are provided. For this example, the storativities, S, for both zones are set equal and representative of elastic formation conditions $\left(\mathrm{S}_{1}=\mathrm{S}_{2}=0.001\right)$. An examination of Figure 3.3 indicates several important features. During early-test times, all the radial boundary examples follow the inner zone response (i.e., homogeneous formation response), with the duration of coincidence being directly associated with distance to the radial boundary. The presence of the radial boundary is exhibited by the departure from inner zone response, where the test response becomes flatter (recovery rate decreases) and transitions to a combined composite test response, reflective of the hydraulic properties inside and outside the radial boundary. Recognizing whether radial flow boundaries are present within the slug-test response may be difficult unless the transition period segments of the test are distinct. Recognizing the presence of radial boundaries, however, is more apparent when slug test derivative plots are employed.

Figure 3.4 shows the predicted slug-test derivative responses for the same test conditions presented in Figure 3.3. As shown, radial boundaries for the distances greater than $0.5 \mathrm{~m}$ are denoted by a derivative pattern exhibiting multiple peaks or a stair-step pattern, which is in contrast to the smooth, single peak derivative pattern exhibited by homogeneous formations. For radial distances extremely close (e.g., $<0.5 \mathrm{~m}$ ) or far (e.g., $>5 \mathrm{~m}$ ) from the test well, the presence of boundaries may not be detected within the test response.

Figure 3.5 shows the predicted slug-test responses for a positive finite-thickness skin condition, where the inner zone has a $\mathrm{K}_{\mathrm{h}} 0.01$ times that of the outer zone, for the same selected radial boundary distances $(0.5,1,2 \mathrm{~m})$ and test conditions examined for the negative skin case (only the $\mathrm{K}_{\mathrm{h}}$ values for the inner and outer zones are reversed). As for the previous negative-skin example, during early-test times, the various heterogeneous responses follow the inner zone response (i.e., homogeneous formation response), with the duration of coincidence being directly associated with distance to the radial boundary. The presence of the radial boundary is exhibited by the departure from inner zone response, where the test response becomes steeper (recovery rate increases), with test recovery becoming reflective of a combined composite test response reflective of the hydraulic properties inside and outside the radial boundary. The increased steepness in test response due to the presence of a radial boundary (positive-skin), becomes more apparent when type-curve analysis methods are used (i.e., in comparison to the Bouwer and Rice method). As discussed in Butler (1997), the analysis of slug tests affected by positive-skin conditions often requires use of homogeneous formation type curves with unrealistically low storativity values (i.e., to match the entire test response). For this reason, Butler (1997) recommends the use of type-curve analysis for slug tests to detect whether positive skin-radial boundaries are present within the test response.

Only one of the wells (well 299-W26-14) tested during FY 2003 exhibited effects of heterogeneous formation-radial boundary conditions (i.e., higher $\mathrm{K}$ inner zone). No complete slug-test response analyses (i.e., using $\mathrm{K}_{\mathrm{h}}$ values for the inner and outer zones) were attempted, however, using the finite-thickness, skin solution available within the KGS program (as shown in Figures 3.3, 3.4, and 3.5). This is due to the non-uniqueness of the analytical solution (i.e., similar test responses can be derived using different combinations of K, S and skin/inner zone thickness). For the test exhibiting heterogeneous formation behavior, the inner and outer zone test responses were analyzed independently using the homogeneous 


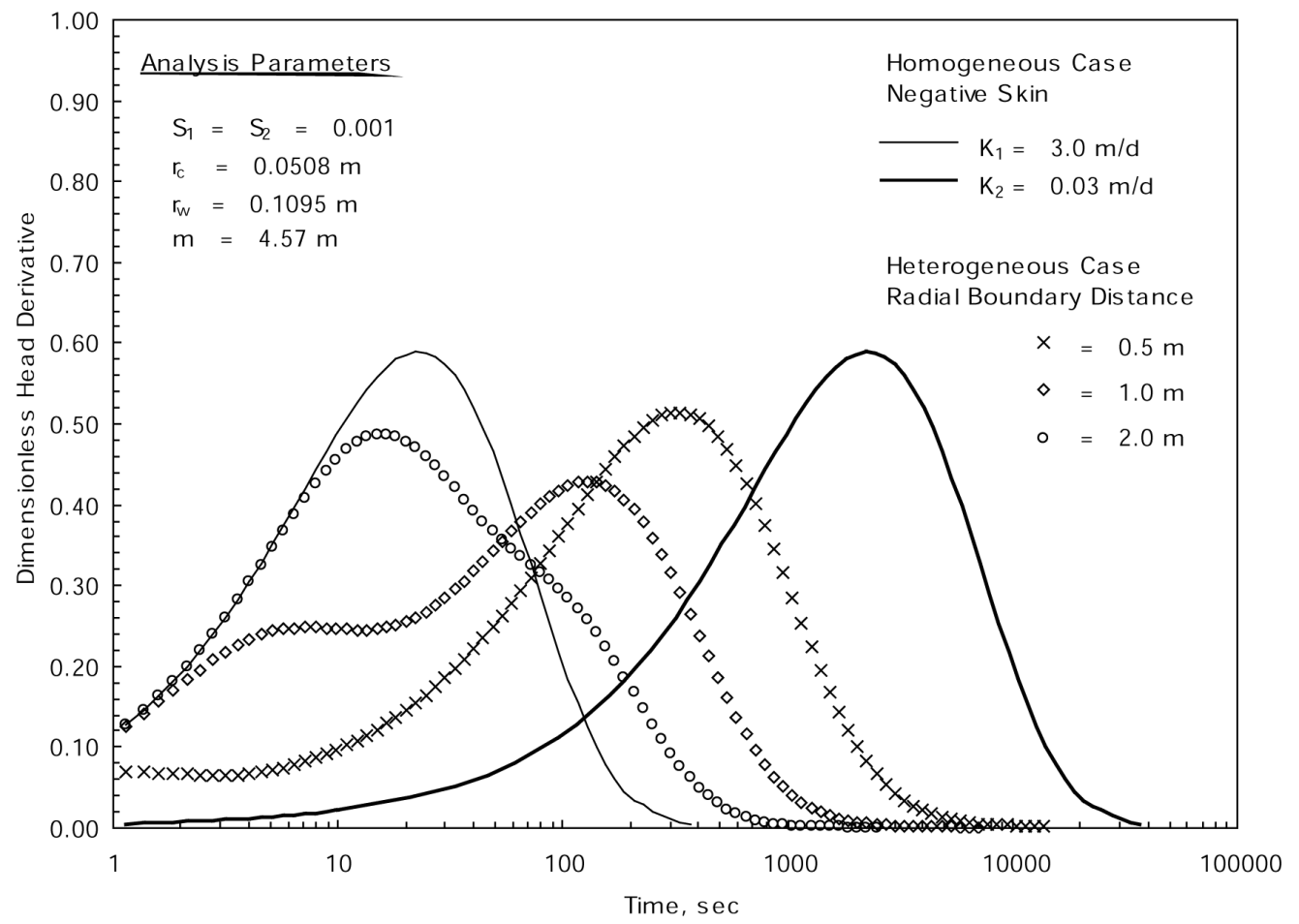

Figure 3.4. Predicted Slug-Test Derivative Response: Negative Finite-Thickness Skin Conditions

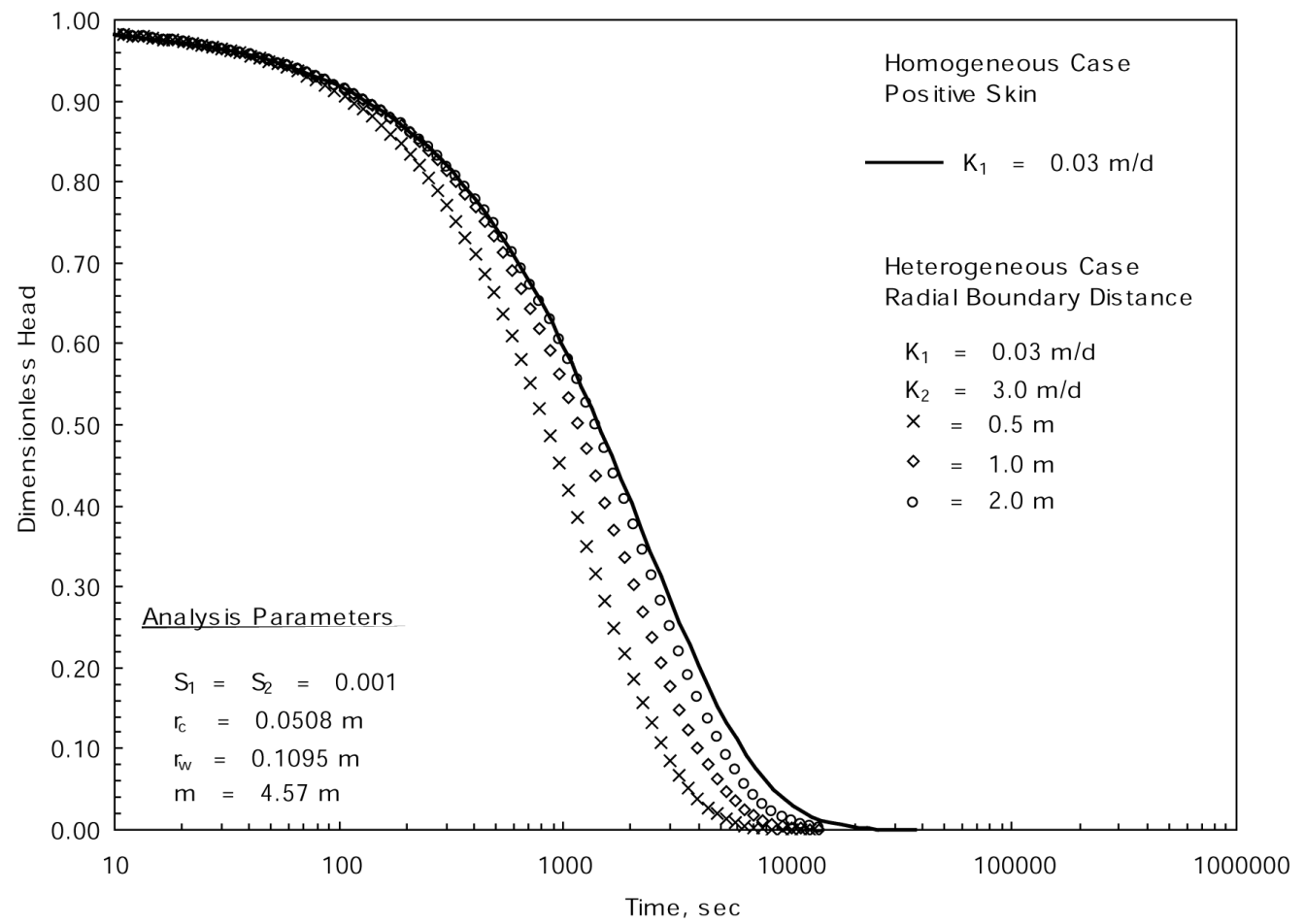

Figure 3.5. Predicted Slug-Test Response: Positive Finite-Thickness Skin Conditions 
formation analysis approach. (Note: this is a departure from the complete analysis approach used in Spane et al. (2001b) for the analysis of three test wells exhibiting heterogeneous formation response conditions).

For the outer zone test response, which is more representative of actual formation/aquifer conditions, the homogeneous formation analysis procedure outline in Butler (1997) was used. This procedure is similar to the method described in Section 3.1 to calculate the actual stress level, $\mathrm{H}_{\mathrm{p}}$. For a homogeneous formation analysis of the outer zone test response, the early-time test data reflecting the higher permeability inner zone is ignored and an initial, outer zone test stress level $\left(\mathrm{H}_{\mathrm{p}-\mathrm{out}}\right)$ is calculated by projecting the observed, outer zone test data back to the time of test initiation. For analysis of the outer zone response, an equivalent well radius, $r_{\text {eq-out }}$, must be used instead of the actual well-casing radius, $r_{c}$, in the various analytical methods. The $\mathrm{r}_{\text {eq-out }}$ is calculated by using Equation 3.1, substituting $\mathrm{H}_{\mathrm{p} \text {-out }}$ for $\mathrm{H}_{\mathrm{p}}$ in the equation.

\subsubsection{High Permeability/Under-Damped Analysis Methods}

Slug-test response within highly permeable formations is commonly influenced by processes (e.g., inertial) that are not accounted for in the previously discussed analytical methods. For Hanford Site conditions, high permeability formation conditions can be expected when test responses are underdamped or critically damped, and exhibit any or all of the following characteristics:

- complete recovery within 10 seconds

- oscillatory recovery pattern

- overly-steep type-curve recovery and heightened derivative plot pattern

- concave downward Bouwer and Rice plot

Slug tests exhibiting these response characteristics cannot be analyzed quantitatively using the Bouwer and Rice (Section 3.1.1.1) or type-curve (Section 3.1.1.2) methods. As noted previously, methods that can be employed for analyzing unconfined aquifer tests exhibiting high permeability characteristics include methods described in Springer and Gelhar (1991), Butler (1997), McElwee and Zenner (1998), McElwee (2001), Butler and Garnett (2000), and Zurbuchen et al. (2002). Because of the ease provided by a spreadsheet-based approach, the test analysis method presented in Butler and Garnett (2000) was used for tests exhibiting high permeability response characteristics, i.e., under- or criticallydamped. The technique employs a type-curve generating/matching procedure wherein the analyst:

- first, generates a test type-curve response (based on test/well input parameters) that matches the general recovery amplitudes for peaks and troughs exhibited by the observed slug test response pattern, by adjusting the response damping parameter, $\mathrm{C}_{\mathrm{D}}$, and then

- adjusts the generated type curve response using the modulation factor for matching the oscillatory period exhibited by the observed slug test response

In most test cases, the exhibited test response period is largely controlled by the test and well characteristics (e.g., $r_{c}, r_{w}, L, L_{e}$ ), while the recovery amplitudes exhibited by the test peaks and troughs is highly dependent on test formation permeability. Figure 3.6 shows the affect of test formation permeability on the recovery amplitudes of peaks and troughs, and duration of oscillatory response. As 
indicated, lower test interval permeabilities exhibit more rapidly damped response patterns, while higher test interval permeabilities are denoted by less amplitude attenuation and longer test response durations.

Similar analysis procedures are utilized for tests exhibiting critically-damped behavior. The only difference being the number of match points for the generated test simulation to the observed test response, which are commonly limited to only one peak and trough, and the recovery point to static, pretest conditions. For FY 2003, slug tests conducted at test wells 299-E24-22, -E25-93, and -E27-23 were analyzed using the high permeability analysis approach. These analysis results are discussed in Chapter 4.0.

It should be noted that the High-K analysis method requires that the pressure sensor utilized during testing be located in close proximity to the water-table surface, as discussed in Zurbuchen et al. (2002) and Butler et al. (2003). This is due to the effects of water-column acceleration within the well. Because of testing constraints at these three sites, the pressure sensor was located $>2 \mathrm{~m}$ below the water-column surface. As a result, hydraulic characteristics derived from these tests may be lower than reported, due to damping effects imposed by the exhibited fluid-column acceleration. A description of the performance and analysis of slug tests conducted at each well site is presented in Chapter 4.0.

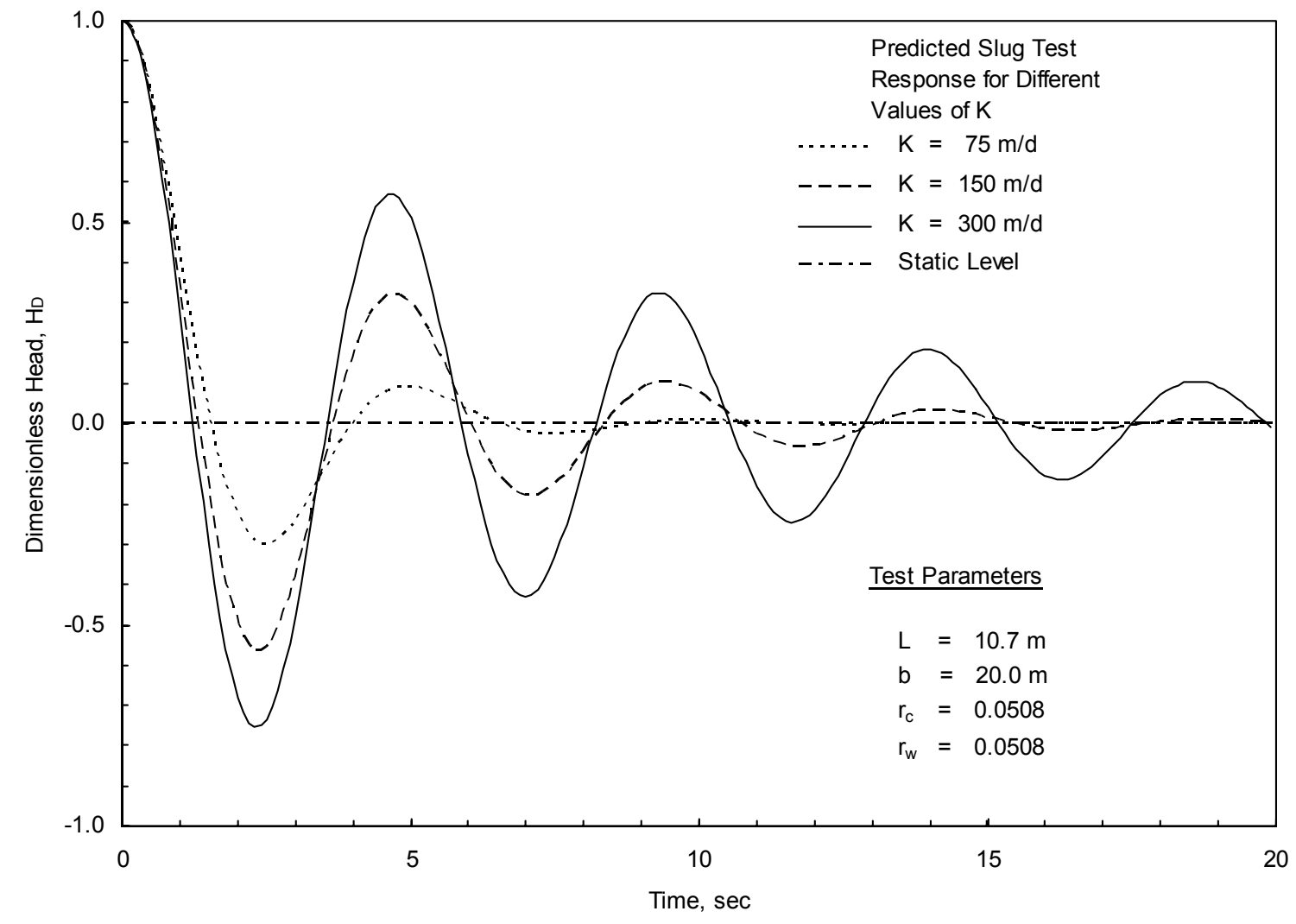

Figure 3.6. Effects of Hydraulic Conductivity on Predicted Under-Damped Slug-Test Response 


\subsection{Single-Well Tracer Tests}

Tracer tests are the primary field test method used to characterize in-situ hydrologic and transport parameters that control the subsurface movement of groundwater contaminantion. Transport characterization information is necessary for the safe disposal of radioactive and/or hazardous waste and effective contaminant remediation. Single-well tracer tests can provide information on groundwater-flow characteristics (e.g., flow velocity) and aquifer properties (i.e., vertical distribution of K, effective porosity, $\mathrm{n}_{\mathrm{e}}$ ). During FY 2003, single-well tracer tests included tracer-dilution, tracer-pumpback, and in-well vertical flow tracer. Performance and analysis methods for the various single-well tracer tests are described in the following sections.

\subsubsection{Tracer-Dilution Tests}

For the tracer-dilution test, a bromide solution of known concentration was mixed within the wellscreen section. The decline of tracer concentration (i.e., dilution) over time within the well screen was monitored directly using a vertical array of bromide-specific ion-electrode sensors located at known depth intervals. The sensors were calibrated in the laboratory with standards of known bromide concentration prior to and following performance of the tracer-dilution test. Based on the dilution characteristics observed, the vertical distribution (i.e., heterogeneity) of hydraulic properties and/or in-well flow velocity can be estimated for the formation section penetrated by the well screen. The presence of vertical flow within the well screen can also be identified from the sensor/depth-dilution-response pattern. A description of the performance and analysis of tracer-dilution test characterization investigations is provided in Halevy et al. (1966), Hall et al. (1991), and Hall (1993).

Essential design elements of a tracer-dilution test include establishing a known, constant tracer concentration within the test section by mixing or circulating the tracer solution in the wellbore/test interval and monitoring the decline of tracer concentration with time within the test interval.

The decline in tracer concentration within the wellbore can be analyzed to ascertain the hydraulic gradient, I (if the formation's $\mathrm{K}$ is known) or the test-interval $\mathrm{K}$ (if the hydraulic gradient is known) using the following analytical expression:

$$
\ln \left(\mathrm{C} / \mathrm{C}_{\mathrm{o}}\right)=-\left(\mathrm{Q}_{\mathrm{w}} \mathrm{t}\right) / \mathrm{V}_{\mathrm{w}}
$$

where $\quad \mathrm{C}=$ concentration of the tracer in the test interval at time, $\mathrm{t}$

$\mathrm{C}_{\mathrm{o}}=$ initial concentration of the tracer at the start of the test

$\mathrm{Q}_{\mathrm{w}}=$ in-well lateral groundwater discharge within the well-test interval

$\mathrm{V}_{\mathrm{w}}=$ isolated test interval well volume

For test-analysis purposes, Equation 3.3 is commonly rewritten to calculate the groundwater-flow velocity within the well, $\mathrm{v}_{\mathrm{w}}$, as follows:

$$
\mathrm{v}_{\mathrm{w}}=\mathrm{d}(\ln \mathrm{C}) / \mathrm{dt} /(-\mathrm{A} / \mathrm{V})
$$

where $\mathrm{A}=$ cross-sectional area within well screen; $\mathrm{L}^{2}$

$\mathrm{V}=$ well volume over measurement section; $\mathrm{L}^{3}$ 
As shown by Halevy et al. (1966), to take into account the cross-sectional/well-measurement volume effects of the emplaced in-well tracer-measurement system (downhole probe, cables), Equation 3.4 can be rewritten as

$$
\mathrm{v}_{\mathrm{w}}=\mathrm{d}(\ln \mathrm{C}) / \mathrm{dt} /-\left[2 \mathrm{r}_{\mathrm{w}} / \pi\left(\mathrm{r}_{\mathrm{w}}^{2}-\mathrm{r}_{\mathrm{t}}^{2}\right)\right]
$$

where $r_{w}=$ radius of well screen; $\mathrm{L}$

$r_{t}=$ equivalent radius of tracer-measurement system; $\mathrm{L}$

The calculated $\mathrm{v}_{\mathrm{w}}$ is not the groundwater-flow velocity within the aquifer, $\mathrm{v}_{\mathrm{a}}$. The $\mathrm{v}_{\mathrm{w}}$ is related to actual groundwater velocity within the aquifer by the following relationship:

$$
\mathrm{v}_{\mathrm{w}}=\mathrm{v}_{\mathrm{a}} \mathrm{n}_{\mathrm{e}} \propto
$$

where $\mathrm{n}_{\mathrm{e}}=$ effective porosity; dimensionless

$\propto=$ groundwater-flow-distortion factor; dimensionless, common range 0.5 to 4

Various aspects of conducting tracer-dilution tests (i.e., test design, influencing factors) have been discussed previously by a number of investigators (e.g., Halevy et al. 1966; Freeze and Cherry 1979). Following completion of the tracer-dilution test, the tracer can be recovered from the formation by pumping, and the results analyzed to assess the effective porosity within the test interval. Tracer-pumpback tests are discussed in the following section.

Some investigators have noted differences in hydraulic property estimates obtained with tracerdilution techniques and other test methods (e.g., Drost et al. 1968; Kearl et al. 1988). These differences were attributed, in some cases, to distortions in the flow field caused by increased (or decreased) permeability near the well.

Analysis details and results for tracer-dilution tests conducted at each of the selected test wells during FY 2003 are provided in Chapter 5.0.

\subsubsection{Tracer-Pumpback Tests}

Detailed procedures to conduct standard, single-well, conservative tracer tests are provided in Pickens and Grisak (1981) and Molz et al. (1985). The tracer pumpback includes the following basic test procedure:

- emplace a conservative tracer (bromide) within the well/aquifer system

- define a prescribed residence (drift) time for the tracer to be dispersed within the aquifer

- withdraw the tracer from the well/aquifer system by pumping at a constant rate

- monitor tracer concentrations at the test well (bromide sensor/flow cell) and collect discrete groundwater samples for quantitative laboratory analysis 
The tracer-testing program relied on natural groundwater flow to emplace the tracer and did not include actual injection of the bromide tracer into the surrounding aquifer. Because of the relatively small area represented by the well (i.e., in comparison to the aquifer) and volumes of tracer involved, the results obtained from these tracer tests may be more susceptible to wellbore effects (e.g., $\propto$ and possible downgradient dead zone).

For the tracer-pumpback tests, a constant-rate pumping test is initiated after the average tracer concentration decreases (i.e., is diluted) to a sufficient level within the well screen (usually a one-to-two order of magnitude reduction from the original tracer concentration). The objective of the pumpback test is to capture the tracer that has moved from the well into the surrounding aquifer. Tracer recovery is monitored qualitatively by measuring the tracer concentration at the surface using a bromide sensor/flow cell installed in the discharge line. Discrete samples are collected at the surface at preselected times for quantitative laboratory tracer analysis.

The time required to recover the center of tracer mass from the aquifer provides information concerning $\mathrm{n}_{\mathrm{e}}$ and $\mathrm{v}_{\mathrm{a}}$. $\mathrm{n}_{\mathrm{e}}$ is a primary hydrologic parameter that controls contaminant transport. Analytical methods available for the analysis of single-well, tracer injection/withdrawal tests include (in addition to the previously cited references) Güven et al. (1985), Leap and Kaplan (1988), and Hall et al. (1991). The procedure to analyze the tracer-pumpback results is based on a rearrangement of the equations presented in Hall et al. (1991), which combines the basic pore velocity groundwater-flow equation (Equation 3.7) with the regional advective flow-velocity equation (Equation 3.8) describing tracer-drift and -pumpback tests as reported in Leap and Kaplan (1988).

$$
\begin{gathered}
\mathrm{v}_{\mathrm{a}}=(\mathrm{K} \mathrm{I}) / \mathrm{n}_{\mathrm{e}} \\
\left.\mathrm{v}_{\mathrm{a}}=\left[\left(\mathrm{Q} \mathrm{t}_{\mathrm{p}}\right) / \pi \mathrm{n}_{\mathrm{e}} \mathrm{b}\right)\right]^{1 / 2} / \mathrm{t}_{\mathrm{t}}
\end{gathered}
$$

Combining and rearranging results in

$$
\mathrm{v}_{\mathrm{a}}=\left(\mathrm{Q} \mathrm{t}_{\mathrm{p}}\right) /\left(\pi \mathrm{bt} \mathrm{t}_{\mathrm{t}}^{2} \mathrm{KI}\right)
$$

and

$$
\mathrm{n}_{\mathrm{e}}=\left(\pi \mathrm{b} \mathrm{t}_{\mathrm{t}}^{2} \mathrm{~K}^{2} \mathrm{I}^{2}\right) /\left(\mathrm{Q} \mathrm{t}_{\mathrm{p}}\right)
$$

where $\mathrm{v}_{\mathrm{a}}=$ advective groundwater-flow velocity within the aquifer; $\mathrm{L} / \mathrm{T}$

$\mathrm{n}_{\mathrm{e}}=$ effective porosity; dimensionless

$\mathrm{K}=$ hydraulic conductivity; $\mathrm{L} / \mathrm{T}$

$\mathrm{I}=$ local hydraulic gradient; dimensionless

$\mathrm{b}=$ aquifer thickness; $\mathrm{L}$

$\mathrm{Q}=$ tracer-pumpback rate; $\mathrm{L}^{3} / \mathrm{T}$

$t_{p}=$ pumping time required to recover the center of mass of tracer emplaced into the aquifer

$t_{t}=$ total elapsed time equal to sum of the tracer drift time, $t_{d}$, (time from tracer emplacement to start of recovery pumping) and $t_{p}$ 
The K values used in Equations 3.9 and 3.10 were determined from analysis of constant-rate pumping tests for the test well (i.e., during the tracer pumpback). The I value was determined using trend-surface analysis of water-level elevation measurements from nearby wells as described in Section 3.4. The $\mathrm{b}$ value was calculated directly from geologic information obtained for the well or projection from known geologic relationships at nearby wells.

To calculate the time required to recover the tracer center of mass emplaced into the aquifer, several steps were required. The bromide concentration versus time profile during the pumpback test was determined by laboratory analysis of discrete samples collected closely over time. The mass of tracer recovered with time was calculated, based on integrating the product of the exhibited tracer concentration profile and observed pumping rate during the test. The $t_{p}$ value, to the center of mass, was calculated by dividing the tracer mass recovered by the actual tracer mass transported into the aquifer. To calculate the actual tracer mass within the aquifer, the mass within the well-screen column and surrounding well sandpack at the start of the pumpback test was subtracted from the initial mass emplaced in the well. The mass within the well screen was determined by multiplying the known well-screen volume by the average concentration, which was calculated by the final readings of the bromide sensors used during the tracer-dilution test. The sensors were removed generally within 2 hours of initiation of the tracer pumpback; therefore, their final readings are representative of initial pumpback conditions. For calculating the tracer mass within the sandpack, the study assumed that the tracer concentration was the same as observed within the well screen. Sandpack volumetric calculations were based on available as-built information, a porosity of $25 \%$, and the assumption that $50 \%$ of the sandpack (i.e., the downgradient side) would be occupied by tracer.

The mathematical relationship to calculate half the tracer mass recovered during the pumpback, $\mathrm{M}_{50 \%}$, which is the mass used to calculate the center of mass recovery time, $t_{p}$, then can be expressed as:

$$
\mathrm{M}_{50 \%}=0.50\left(\mathrm{M}_{\mathrm{r}}-\mathrm{M}_{\mathrm{w}}\right) /\left(\mathrm{M}_{\mathrm{i}}-\mathrm{M}_{\mathrm{w}}\right)
$$

where $\mathrm{M}_{\mathrm{r}}=$ mass of tracer recovered during the tracer pumpback; $\mathrm{M}$

$\mathrm{M}_{\mathrm{w}}=$ mass of tracer within well screen and well sandpack at the beginning of the tracer pumpback; $\mathrm{M}$

$\mathrm{M}_{\mathrm{i}}=$ mass of tracer initially emplaced in the well; $\mathrm{M}$

The $t_{p}$ also was corrected (reduced) to account for the transit time of the pumped water from the pump intake to land surface (i.e., location where laboratory samples were collected).

Analysis details and results for tracer-pumpback tests conducted at each of the selected test wells are provided in Chapter 6.0.

\subsubsection{In-Well Vertical Flow Assessment}

As discussed in Section 3.2.1, the successful performance of tracer-dilution tests requires that lateral groundwater-flow conditions exist within the well fluid column. The presence of vertical flow is indicated during the initial phases of tracer dilution if a systematic, "stair-step," tracer-dilution pattern is exhibited for the respective depth settings of the bromide sensor. Figure 3.7 illustrates a hypothetical tracer-dilution pattern for various depths for a downward vertical flow condition within the well screen. 


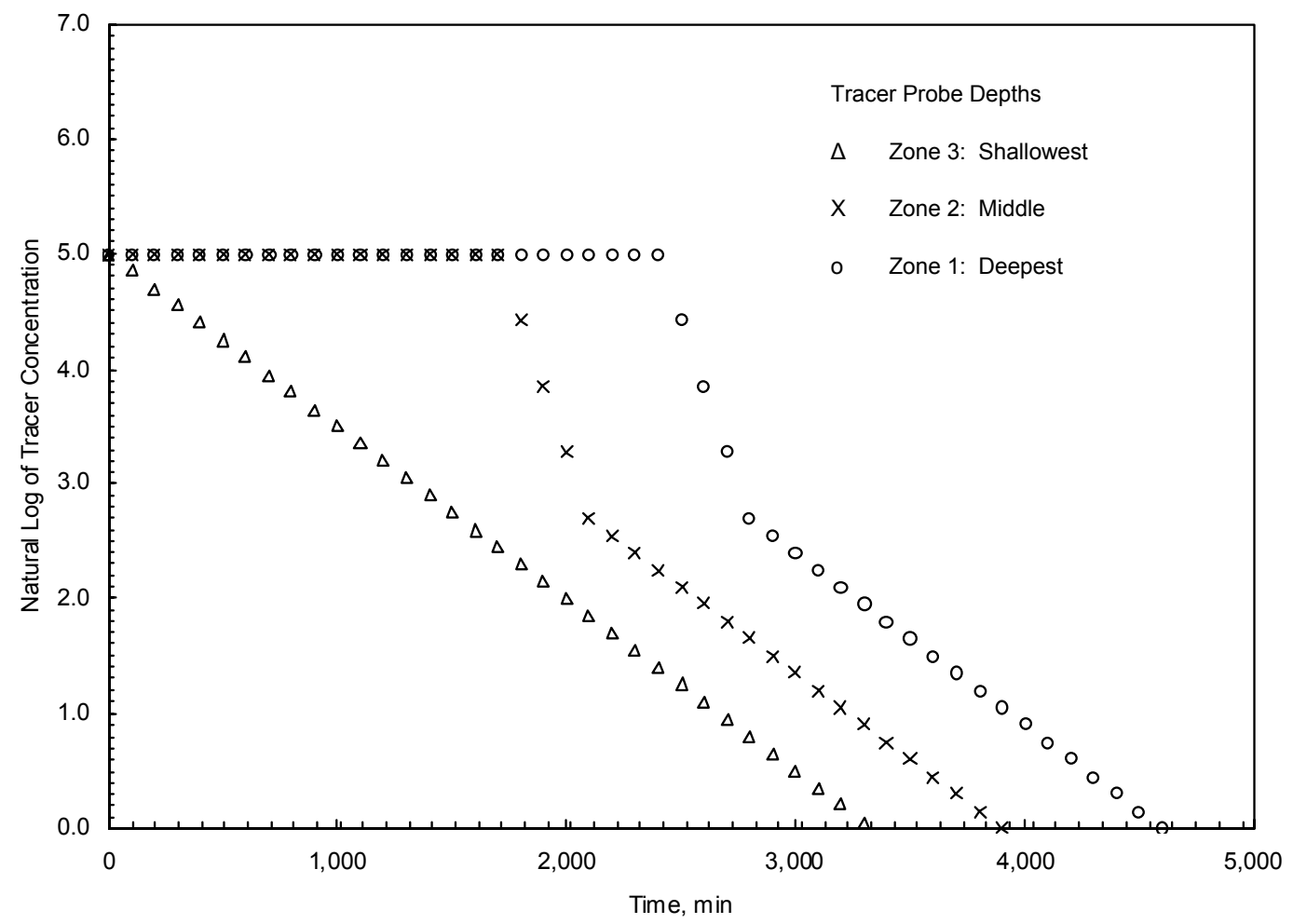

Figure 3.7. Hypothetical Tracer-Dilution Pattern Indicative of Vertical In-Well Downward Flow

As shown, the pattern evolves with time (after the tracer has been uniformly mixed within the well-screen section) as a result of the downward flow/mixing of nontracer groundwater. As shown in Figure 3.7, the pattern is characterized by a progressive extension of a constant tracer concentration for the sensors at greater depths, followed by a rapid decline of tracer on arrival of the downward flow mixture of tracer and nontracer groundwater. During late test times, the various tracer versus depth profiles exhibit a parallel-linear pattern. In-well vertical flow, $\mathrm{v}_{\mathrm{v}}$, can be calculated by using the arrival time of the tracer/nontracer groundwater mixture front at the various known depth/sensor spacings.

In previous site investigations, the presence of in-well vertical flow conditions was quantified using three different test methods: tracer-dilution pattern analysis, vertical flow-tracer tests, and electromagnetic vertical flow-meter surveys. As reported in Spane et al. (2001a, 2001b) close corroboration was exhibited between the three test methods. Because of budgetary constraints, in-well vertical flow conditions indicated by performing tracer-dilution tests were not investigated using either vertical flowtracer tests or electromagnetic surveys during FY 2003. Results of in-well vertical flow conditions for tests conducted during FY 2003 are based only on tracer-dilution pattern assessment and are presented in Chapter 5.0. As discussed in Section 5.1, well 299-E26-10 exhibited tracer dilution patterns indicative of in-well vertical flow conditions. A discussion of the other in-well vertical flow characterization methods not used during the FY 2003 well tests is presented in Spane et al. (2001a, 2001b). 


\subsection{Constant-Rate Pumping Tests}

Constant-rate pumping tests are the principal field test method to characterize hydraulic and storage properties of aquifers. For constant-rate pumping tests, groundwater is pumped from a well at a controlled-uniform rate. The associated water-level drawdown within the test well during pumping, and the recovery water-level response following termination of pumping are analyzed to provide in-situ property determinations.

Drawdown and recovery water levels were measured during tracer-pumpback tests for one LERF well (299-E26-10) selected for detailed hydrologic characterization. Diagnostic analysis of the test responses was first conducted to determine test system characteristics and to identify test data that display infiniteacting radial flow behavior. Analysis of the drawdown and recovery phases of constant-rate discharge were then performed by type-curve fitting of $\log$-log plots and, if appropriate, by straight-line analysis of semilogarithmic data plots of water-level change versus time. Test performance and methods used to analyze the results obtained from constant-rate testing are described in this section. Analysis details and results for the selected test well is provided in Chapter 7.0.

\subsubsection{Test Methods and Equipment}

A 3-hp Grundfos ${ }^{\circledR}$ submersible pump was used to remove water during each pumping test. Flow rates were monitored with a surface turbine flow meter (inside diameter $0.025 \mathrm{~m}, \mathrm{Arad}^{\circledR}$, model \#555061). Flow was adjusted manually using a gate valve to maintain constant-rate conditions. During the initial minutes of pumping (e.g., first 3 minutes), "instantaneous" flow rates were determined by measuring the time required for $19 \mathrm{~L}$ of flow to register on the flow-meter dials. Flow-meter totalizer readings were recorded every 5 to 20 minutes during pumping. Druck, Inc., 0 to $10 \mathrm{psig}$, differential pressure transducers (model \# PDCR $^{\circledR}$ 1830-8388) were used to monitor water levels in the pumping well and the nearby monitor wells during the test. The transducers were vented at the surface to compensate automatically for atmospheric pressure fluctuations. Pressure transducer measurements were recorded using a Campbell Scientific, Inc. model CR-10X ${ }^{\mathrm{TM}}$ data logger.

Because tracer recovery also was being monitored during the tracer-pumpback test, part of the discharged groundwater was routed through a flow-through cell containing a bromide-selective ion probe, and a sampling port was used to collect water for laboratory analysis of the bromide tracer. These devices were downstream from the flow meter. The discharged water during the pumping test was collected in a tank truck for subsequent disposal at an effluent disposal facility.

\subsubsection{Barometric Pressure Effects Removal}

The analysis of well water-level responses during hydrologic tests provides the basis to estimate hydraulic properties that are important to evaluate groundwater-flow velocity and transport characteristics. Barometric pressure fluctuations, however, can have a discernible impact on well water-level measurements. Although the pressure transducers were vented to compensate for changes in barometric pressure, barometric pressure fluctuations also can cause changes in the water level in a well. This response effect is commonly ascribed to confined aquifers; however, wells completed within unconfined 
aquifers may also exhibit associated responses to barometric changes (Weeks 1979; Rasmussen and Crawford 1997). Water levels in unconfined aquifers typically exhibit variable time-lagged responses to barometric fluctuations. This time-lag response is caused by the time required for the barometric pressure change to be transmitted to the water table through the vadose zone compared to the instantaneous transmission of barometric pressure through the open well.

To determine the significance of barometric effects, water-level changes were monitored during a baseline period before or after each constant-rate discharge test and compared to the corresponding barometric pressure changes. Barometric pressures were obtained from the Hanford Meteorology Station (located immediately east of the 200-West Area), where they are recorded hourly. The barometric responses were then analyzed and removed from the recorded water levels using the multiple-regression deconvolution techniques described in Rasmussen and Crawford (1997) and Spane (1999, 2002). This technique relies on a least-squares fit of the water-level change to the corresponding barometric pressure change and time-lagged earlier barometric pressure changes. As noted in Spane (1999), under prevalent conditions in the 200-West and East Areas, no significant difference in removal efficiency was derived in using data collected at higher recording frequencies (e.g., 10 minutes). Therefore, data collected at a 1 -hour frequency were used in the process for barometric pressure removal.

Because barometric changes were recorded at a constant 1-hour frequency, the relationship between water level and barometric change can be represented as follows:

$$
\Delta \mathrm{h}_{\mathrm{w}}=\mathrm{X}_{0} \Delta \mathrm{h}_{\mathrm{ai}}+\mathrm{X}_{1} \Delta \mathrm{h}_{\mathrm{ai}-1}+\mathrm{X}_{2} \Delta \mathrm{h}_{\mathrm{ai}-2}+\ldots+\mathrm{X}_{\mathrm{n}} \Delta \mathrm{h}_{\mathrm{ai}-\mathrm{n}}
$$

where $\Delta \mathrm{h}_{\mathrm{w}}=$ water-level change over the last hour

$\Delta \mathrm{h}_{\mathrm{ai}}=$ barometric pressure change over the last hour

$\Delta \mathrm{h}_{\mathrm{ai}-1}=$ barometric pressure change from 2 hours to 1 hour previous

$\Delta \mathrm{h}_{\mathrm{ai}-\mathrm{n}}=$ barometric pressure change from $\mathrm{n}$ hours to ( $\left.\mathrm{n}-1\right)$ hour previous

$\mathrm{X}_{0} \ldots \mathrm{X}_{\mathrm{n}}=$ regression coefficients corresponding to time lags of 0 to $\mathrm{n}$ hours

$\mathrm{n}=$ number of hours that lagged barometric effects are apparent

After calculating $\mathrm{X}_{0} \ldots \mathrm{X}_{\mathrm{n}}$, simulated well water levels associated with the hourly barometric responses were calculated from the above equation for the baseline period. The results were then compared to the actual observed well water-level response for a "goodness of fit" evaluation. To remove barometric effects from water levels recorded during the constant-rate discharge test, a simulated well water-level response was calculated based on the hourly barometric changes that were observed over the test period. The predicted barometric induced response was then subtracted from the recorded pumping test water-level measurements. Analysis techniques described in the following section were then applied to the data after removal of barometric effects.

\subsubsection{Unconfined Aquifer Dewatering Drawdown Correction}

In thin aquifers where drawdown represents a significant percentage of the total saturated thickness, corrections for dewatering of the unconfined aquifer are required to account for the decrease in associated aquifer transmissivity. Jacob (1963) provided an equation to correct drawdown data obtained for 
pumping tests within thin unconfined aquifers. The corrected drawdown, s', which accounts for aquifer dewatering can be calculated using the following relationship:

$$
s^{\prime}=s-\left(s^{2} / 2 \mathrm{~b}\right)
$$

where $\mathrm{s}=$ observed drawdown

$\mathrm{b}=$ initial saturated aquifer thickness

For most previously tested Hanford Site well locations, drawdown represented only a small part of the total aquifer thickness (e.g., 200-West Area). Drawdown data correction, as listed in Equation 3.13, is largely inconsequential, particularly when type-curve analysis methods are employed. However, for well 299-E26-10 that was tested during FY 2003, the initial saturated unconfined aquifer thickness was $\sim 2 \mathrm{~m}$, and drawdown data corrections were required for quantitative test analysis.

\subsubsection{Diagnostic Analysis and Derivative Plots}

Log-log plots of water level versus time have traditionally been used for diagnostic purposes to examine pumping test drawdown data. More recently, the derivative of the water level or pressure has also been used (Bourdet et al. 1989; Spane 1993) as a diagnostic tool. Use of derivatives has been shown to improve significantly the diagnostic and quantitative analysis of various hydrologic test methods (Bourdet et al. 1989; Spane 1993). The improvement in test analysis is attributed to the sensitivity of pressure derivatives to various test/formation conditions. Specific applications for which derivatives are particularly useful include the following:

- determining formation-response characteristics (confined or unconfined aquifer) and boundary conditions (impermeable or constant head) that are evident within the test data

- assisting in the selection of the appropriate type-curve solution through combined type-curve/ derivative plot matching

- determining when infinite-acting, radial flow conditions are established and, therefore, when straight-line analysis methods are applicable

Figure 3.8 shows log-log drawdown and derivative responses that are characteristic of some commonly encountered formation conditions. The early data, occurring before the straight-line approximation is valid or where wellbore storage is dominant, produce a steep, upward-trending derivative. The derivative normally decreases during transition from wellbore storage to radial flow and stabilizes at a constant value when infinite-acting, radial flow conditions are established. The stable derivative reflects the straight line on the semilog plot for infinite-acting radial flow. Unconfined aquifers and formations exhibiting double-porosity characteristics (e.g., fractured media) may show two stable derivative sections at the same vertical position separated by a "valley" that represents the transition from one storage value to the other. Diagnostic derivative plots are also useful to identify boundary effects. 


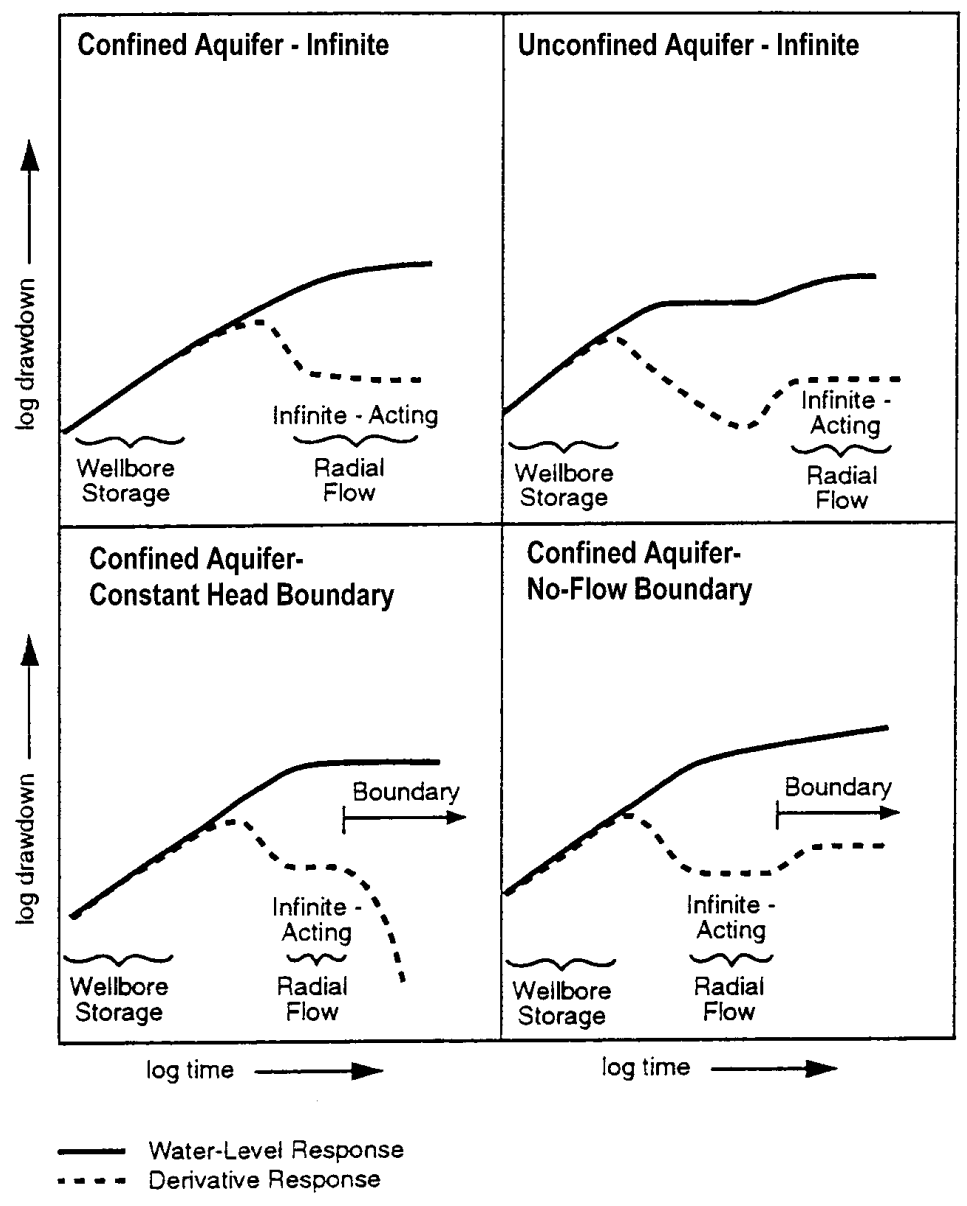

Figure 3.8. Characteristic Log-Log Drawdown and Drawdown Derivative Plots for Various Hydrogeologic Formation and Boundary Conditions

A linear, no-flow boundary will result in a doubling of the magnitude of the derivative. If radial flow is established before the influence of the boundary is seen, a stable derivative will occur for a time followed by an upward shift to twice the original value. Constant-head boundaries display a downward trend in the derivative, which may be preceded by a stable derivative if radial flow conditions occur before the boundary effect becomes dominant. For the diagnostic and test analysis aspects of this report, derivative responses were calculated using the DERIV program described in Spane and Wurstner (1993).

For the pumping test conducted as part of the FY 2003 detailed hydrologic characterization test, the derivative of the water level with respect to the natural logarithm of time (i.e., essentially the slope of the semilog plot) was calculated and plotted on the log-log plots of drawdown versus time. Diagnostic and analysis results of the log-log plot of water-level and associated derivative response for the selected well site obtained for the constant-rate pumping test is provided in Chapter 7.0. 


\subsubsection{Type-Curve-Matching Analysis Methods}

Type-curve-matching methods (Theis 1935; Hantush 1964; Neuman 1972, 1974, 1975) are commonly used to analyze pumping test responses. For this study, unconfined aquifer pumping test type curves were generated using the WTAQ3 computer program described by Moench (1997). WTAQ3 can be used to generate type curves that represent a wide range of test and aquifer conditions, including partially penetrating wells, confined or unconfined aquifer models, well-skin effects, and wellbore storage at both the stress (pump) and observation (monitor) well locations. The type-curve-generation program also allows for noninstantaneous release (drainage-delay factor) of water from the unsaturated zone during the pumping test. However, this was found to not be a significant factor in the analysis; therefore, the type curves used in the analyses for this report all reflect an instantaneous release of water, which was the approach used by Neuman $(1972,1974,1975)$.

In the type-curve-matching procedure, the log-log drawdown or recovery data and its associated derivative response for an individual well were matched simultaneously with dimensionless type-curve responses generated using WTAQ3 (Moench 1997) and the associated derivative plots obtained with the DERIV program (Spane and Wurstner 1993). The dimensionless responses depend on the assumed values of sigma, $\sigma=\mathrm{S} / \mathrm{S}_{\mathrm{y}}$, and vertical anisotropy, $\mathrm{K}_{\mathrm{D}}=\mathrm{K}_{\mathrm{v}} / \mathrm{K}_{\mathrm{h}}$. For initial type-curve-matching runs, the values for $\sigma$ and $K_{D}$ were set at 0.001 and 0.10 , respectively. Minor adjustments were made to the initial $\mathrm{K}_{\mathrm{D}}$ value to improve dimensionless curve matches of the data and associated derivative response patterns. The predicted response also is influenced by the assumed storativity, S, value because of its effect on wellbore storage. After an appropriate dimensionless match to the observed test data was obtained, dimensional curves were generated using the given well/test conditions (e.g., well radius, radial distance to observation well, average pumping rate) and making adjustments to aquifer properties $\left(T, S_{y}\right)$ until the best match with the observed data was obtained. (Note that adjusting $\mathrm{S}_{\mathrm{y}}$ also changes the value of $\mathrm{S}$ because $\sigma$ was held constant.)

Type-curve-matching methods are normally applied to observation well data and not to pumping wells because of the additional head losses that commonly occur at the pumped well. However, in previous analyses of test responses for new RCRA wells in 200-West Area (as reported in Spane 2001a, $2001 \mathrm{~b}$, and 2002), the fitting of type curves to stress well responses resulted in approximately the same $\mathrm{T}$ as fitting type curves to the observation well data. This suggests a high efficiency of the stress well, which incorporates a screen and sand pack in a relatively low-permeability aquifer. Therefore, little head loss appears to be associated with the movement of water into the well during pumping. Because of the similarities in well construction and development activities, it is assumed that the use of type-curve analysis of observed drawdown responses at the pumping well tested during FY 2003 is also appropriate. While this method is expected to provide quantitative estimates for $T$ and $K_{h}$, estimates obtained for $K_{D}$ and $\mathrm{S}_{\mathrm{y}}$ based solely on pumping well data analysis are considered to be only qualitative values. This is attributed primarily to the relative insensitivity of pumping well type curves to $\mathrm{K}_{\mathrm{D}}$, and the relatively short-duration of pumping tests normally conducted on the Hanford Site (e.g., 240 to 360 minutes). 


\subsubsection{Straight-Line Analysis Methods}

For straight-line analysis methods, the rate of change of water levels within the well during drawdown and/or recovery is analyzed to estimate hydraulic properties. Because well effects are constant with time during constant-rate tests, straight-line methods can be used to analyze quantitatively the water-level response at both pumping and observation wells. The semilog, straight-line analysis techniques commonly used are based on either the Cooper and Jacob (1946) method (for drawdown analysis) or the Theis (1935) recovery method (for recovery analysis). These methods are theoretically restricted to the analysis of test responses from wells that fully penetrate nonleaky, homogeneous, isotropic, confined aquifers. Straight-line methods, however, may be applied under nonideal well and aquifer conditions if infiniteacting, radial flow conditions exist. Infinite-acting, radial flow conditions are indicated during testing when the change in pressure, at the point of observation, increases in proportion to the logarithm of time. As discussed in Section 3.3.4, the use of diagnostic derivative methods (Bourdet et al. 1989) makes it easier to identify the portions within the test data where straight-line analysis is appropriate. As will be discussed in Chapter 7.0, derivative analysis of the observed test responses indicated that infinite-acting, radial flow conditions were established at well 299-E26-10 during the constant-rate pumping test. The use of straight-line analysis methods, therefore, is appropriate for this test.

\subsection{Groundwater-Flow Characterization}

To support the detailed hydrologic characterization program, groundwater-flow direction and hydraulic gradient conditions were calculated at the various test sites during the period of tracer testing. Groundwater-flow direction and hydraulic gradient were determined using the commercially available WATER-VEL (In-Situ, Inc. 1991) software program. Water-level elevations from neighboring, representative wells were used as input with the WATER-VEL program to calculate groundwater-flow direction and hydraulic gradient conditions. The program uses a linear, two-dimensional trend surface (least squares) to randomly located hydrologic head or water-level elevation input data. This method is similar also to the linear approximation technique described by Abriola and Pinder (1982) and Kelly and Bogardi (1989). Reports that demonstrate the use of the WATER-VEL program for calculation of groundwater-flow velocity and direction on the Hanford Site include Gilmore et al. (1992) and Spane (1999). Details and results for groundwater-flow characterization at two of the selected test wells are provided in Chapter 8.0. A summary of the results of groundwater-flow characterization is presented in Chapter 9.0. 


\subsection{Slug-Test Results}

Multiple slug tests were conducted at the seven identified wells during FY 2003. The slug tests were initiated by rapidly removing a slugging rod of known volume from the well-screen section. For standard slug test characterizations, two different size slugging rods were used during the tests at each well to impose different stress levels on the test section. The stress levels for the two slugging rods are calculated to impose a slug-withdrawal test response of $0.458 \mathrm{~m}$ (low-stress tests) and $1.117 \mathrm{~m}$ (high-stress tests) within a $0.1016-\mathrm{m}$-inside-diameter well. Because of the small aquifer thickness conditions exhibited at well 299-E26-10, the larger slugging rod used in standard test characterizations could not be utilized. This necessitated using a smaller slugging rod that imposed a slug-withdrawal test response of $0.181 \mathrm{~m}$. This smaller slugging rod, together with the slugging rod that imposed a test response of $0.458 \mathrm{~m}$ was used at this well location.

As noted in Butler (1996), differences exhibited between slug tests conducted at different stress levels can be used to evaluate stress-dependent, non-linear test well effects (e.g., dynamic skin, well development), which are unrelated to aquifer characteristics. Methods used to analyze the slug test results are described in Chapter 3.1. Table 4.1 summarizes the diagnostic slug test response characteristics exhibited at the respective test well locations. As indicated, four test sites exhibited either over-damped or critically-damped/heterogeneous formation conditions. For these diagnostic test conditions, the analytical methods presented in Chapter 3.1.1 (i.e., Bouwer and Rice or type-curve methods) are the appropriate methods utilized for test analysis. For the other three test sites, either under- or critically damped test responses were exhibited. For these tests, the High-K analysis method described in Chapter 3.1.2 was used. As noted in Chapter 3.1.2, the High-K analysis method requires that the pressure sensor utilized during testing be located in close proximity to the water-table surface. This is due to the effects of watercolumn acceleration within the well. Because of testing constraints at these three sites, the pressure sensor was located $>2 \mathrm{~m}$ below the water-column surface. As a result, hydraulic properties derived from these tests may be conservative (i.e., lower than actual), due to damping effects imposed by the exhibited fluid-column acceleration. A summary list of the hydraulic properties determined from slug testing is provided in Table 4.2. A description of the performance and analysis of slug tests conducted at each well site is provided below.

\subsection{Well 299-W19-46}

A total of seven slug tests (four high and three low stress) were conducted on July 22 and 23, 2003. All slug-test responses indicated a heterogeneous formation behavior, with a higher permeability zone located in proximity to the well screen, as indicated by a rapid recovery rate at early test times, which transitions to a slower recovery rate for the surrounding aquifer material (exemplified on the Bouwer and Rice response plot in Figure 4.1). Because of the existing high permeability test interval conditions and rapid recovery of the applied test stress (i.e., $\sim 95 \%$ recovery within $<6$ secs), hydraulic property estimates were based only on the high-stress test results. No analysis of hydraulic properties was attempted for inner-zone conditions that dominate early test times. The extremely rapid recovery and exhibited 
Table 4.1. Slug-Test Characteristics

\begin{tabular}{|c|c|c|c|c|}
\hline \multirow[b]{2}{*}{ Test Well } & \multicolumn{2}{|c|}{ Test Parameters } & \multirow[b]{2}{*}{ Hydrogeologic Unit Tested } & \multirow[b]{2}{*}{ Diagnostic Response } \\
\hline & $\begin{array}{c}\text { Aquifer } \\
\text { Thickness }^{(a)}(\mathrm{m})\end{array}$ & $\begin{array}{c}\text { Test Interval Saturated } \\
\text { Thickness (m) }\end{array}$ & & \\
\hline 299-W19-46 & 57.0 & 10.04 & $\begin{array}{l}\text { Ringold Formation } \\
\text { (Unit 5) }\end{array}$ & $\begin{array}{c}\text { Critically-Damped/Heterogeneous } \\
\text { Formation }\end{array}$ \\
\hline 299-W26-14 & 61.1 & 10.41 & $\begin{array}{l}\text { Ringold Formation } \\
\text { (Unit 5) }\end{array}$ & $\begin{array}{l}\text { Over-Damped/Heterogeneous } \\
\text { Formation }\end{array}$ \\
\hline 299-E24-22 & 25.5 & 10.64 & $\begin{array}{l}\text { Hanford formation } \\
\text { (Unit 1) }\end{array}$ & Under-Damped \\
\hline 299-E25-93 & 28.0 & 10.46 & $\begin{array}{l}\text { Hanford formation } \\
\text { (Unit 1) }\end{array}$ & Critically-Damped \\
\hline 299-E26-10 & 1.98 & 1.98 & $\begin{array}{l}\text { Hanford formation } \\
\text { (Unit 1) and } \\
\text { Elephant Mt. flowtop }\end{array}$ & Over-Damped \\
\hline 299-E26-11 & 3.26 & 1.70 & Elephant Mt. flowtop & Over-Damped \\
\hline 299-E27-23 & 19.35 & 10.67 & $\begin{array}{l}\text { Hanford formation } \\
\text { (Unit 1) }\end{array}$ & Under-Damped \\
\hline
\end{tabular}

Table 4.2. Slug-Test Results

\begin{tabular}{|c|c|c|c|c|c|}
\hline \multirow[b]{2}{*}{ Test Well } & \multirow{2}{*}{$\begin{array}{c}\text { Bouwer and Rice } \\
\text { Analysis Method } \\
\text { Horizontal Hydraulic } \\
\text { Conductivity, } \mathrm{K}_{\mathrm{h},}{ }^{(\mathrm{a})} \\
(\mathrm{m} / \text { day })\end{array}$} & \multicolumn{2}{|c|}{$\begin{array}{c}\text { Type-Curve Analysis } \\
\text { Method } \\
\end{array}$} & \multicolumn{2}{|c|}{$\begin{array}{l}\text { High-K Analysis } \\
\text { Method }^{(b)}\end{array}$} \\
\hline & & $\begin{array}{c}\text { Horizontal Hydraulic } \\
\text { Conductivity, } \mathrm{K}_{\mathrm{h},}{ }^{\text {(a) }} \\
(\mathrm{m} / \text { day })\end{array}$ & $\begin{array}{c}\text { Specific Storage, } \\
\mathrm{S}_{\mathrm{S}}\left(\mathrm{m}^{-1}\right)\end{array}$ & $\begin{array}{c}\text { Horizontal } \\
\text { Hydraulic } \\
\text { Conductivity, } \mathrm{K}_{\mathrm{h},}{ }^{\text {(a) }} \\
(\mathrm{m} / \text { day }) \\
\end{array}$ & $\begin{array}{l}\text { Dimensionless } \\
\text { Damping } \\
\text { Parameter, } \mathrm{C}_{\mathrm{D}} \\
\end{array}$ \\
\hline 299-W19-46 & $\begin{array}{c}33.8-42.1 \\
(38.0)\end{array}$ & $\begin{array}{c}58.8-69.4 \\
(64.1)\end{array}$ & $1.0 \mathrm{E}-4-5.0 \mathrm{E}-05$ & & \\
\hline 299-W26-14 & $\begin{array}{c}\text { Inner Zone: } 2.81-3.74 \\
(3.28) \\
\text { Outer Zone: } 2.72-3.30 \\
(3.01)\end{array}$ & $\begin{array}{c}\text { Inner Zone: } 3.63-4.49 \\
(4.06) \\
\text { Outer Zone: } 3.80-4.23 \\
(4.02)\end{array}$ & $\begin{array}{l}1.0 \mathrm{E}-6-5.0 \mathrm{E}-06 \\
1.0 \mathrm{E}-6-2.0 \mathrm{E}-05\end{array}$ & & \\
\hline 299-E24-22 & NA & NA & NA & $\begin{array}{c}85.8-109^{(b)} \\
(93.6)\end{array}$ & $0.60-0.75$ \\
\hline 299-E25-93 & NA & NA & NA & 49.3 & 8.0 \\
\hline 299-E26-10 & $\begin{array}{l}47.4-54.7 \\
\quad(51.1) \\
\end{array}$ & $\begin{array}{c}36.7-42.8 \\
(39.8) \\
\end{array}$ & $1.0 \mathrm{E}-5$ & & \\
\hline 299-E26-11 & $\begin{array}{l}5.53-6.16 \\
(5.85)\end{array}$ & $\begin{array}{c}6.26-7.34 \\
(6.80)\end{array}$ & $5.0 \mathrm{E}-3$ & & \\
\hline 299-E27-23 & NA & NA & NA & $\begin{array}{c}100-108^{(b)} \\
(104)\end{array}$ & $0.75-0.82$ \\
\hline \multicolumn{6}{|c|}{$\begin{array}{l}\text { Note: see Nomenclature for definitions. } \\
\text { Number in parentheses is the average value. } \\
\text { (a) Assumed to be uniform within the well-screen test section. For tests exhibiting a heterogeneous formation response, only } \\
\text { outer zone analysis results are considered representative of in-situ formation conditions. } \\
\text { (b) Standard analytical methods are not valid. Results based on High-K analysis method presented in Butler and Garnett (2000). }\end{array}$} \\
\hline
\end{tabular}



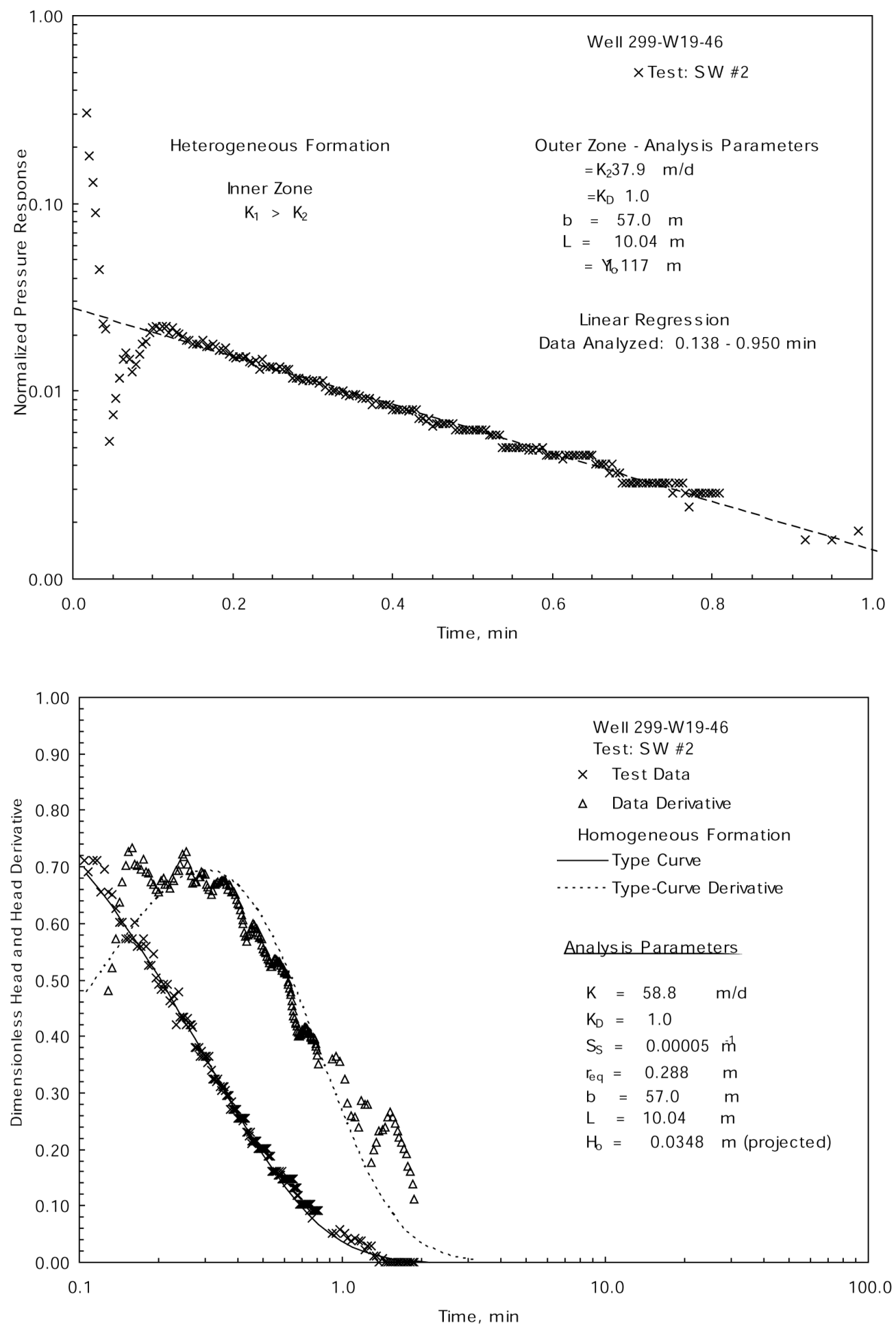

Figure 4.1. Selected Slug-Test Analysis Plots for Well 299-E19-46 (Bouwer and Rice method [top] and type-curve method [bottom]) 
oscillatory behavior, however, are indicative of high permeability conditions. As noted in Chapter 3.0, the inner zone results are believed to be not representative of actual in situ formation conditions and be attributable to a number of artificially imposed conditions (e.g., over well-development, high permeability sandpack installation). For these reasons, only the outer zone analysis results should be used for assessing aquifer formation characteristics at this well location.

Slug tests exhibiting heterogeneous formation test response can be analyzed quantitatively using the homogeneous formation analysis approaches described in Section 3.1.1.3. For the homogeneous formation analysis, the type-curve method estimates for $\mathrm{K}$ ranged between 58.8 and $69.4 \mathrm{~m} /$ day (average $64.1 \mathrm{~m} /$ day) for high stress-level tests for the aquifer outer-zone. Results obtained from the Bouwer and Rice method are generally less definitive for tests exhibiting heterogeneous formation response behavior. A comparison of $\mathrm{K}$ estimates indicates that significantly lower results $(\sim 40 \%)$ were obtained for the Bouwer and Rice method. For the Bouwer and Rice method, estimates of $\mathrm{K}$ for the aquifer outer-zone ranged between 33.8 and $42.1 \mathrm{~m} /$ day (average $38.0 \mathrm{~m} /$ day). Selected examples of the analysis plots for this well are shown in Figure 4.1. As noted in Chapter 3.0, the inner zone results are believed to be not representative of actual in situ formation conditions and may be attributable to a number of artificially imposed conditions (e.g., over well-development, high permeability sandpack installation). For these reasons, only the outer zone analysis results should be used for assessing aquifer formation characteristics at this well location.

\subsection{Well 299-W26-14}

A total of four slug tests (two high and two low stress) were conducted on July 23, 2003. All slugtest responses indicated a heterogeneous formation behavior, with a slightly higher permeability zone located in proximity to the well screen, as indicated by a more rapid recovery rate at early test times, which transitions to a slower recovery rate for the surrounding lower permeability material (exemplified on the Bouwer and Rice response plot in Figure 4.2). A comparison of the normalized, high- and lowstress, slug-test responses indicates a slight delay in the early test-time response behavior for the highstress tests, which is attributable to higher turbulence that occurred for these tests. For this reason, the low-stress test results are believed to provide more representative estimates for formation properties. Nearly identical behavior was evident for tests conducted at a particular stress level, suggesting that the well had been developed sufficiently to establish stable skin conditions.

Slug tests exhibiting heterogeneous formation test response can be analyzed quantitatively using the homogeneous formation analysis approaches described in Chapter 3.1. For the homogeneous formation analysis, the type-curve method estimates for $\mathrm{K}$ ranged between 3.63 and $4.49 \mathrm{~m} /$ day (average $4.06 \mathrm{~m} /$ day) for both stress-level tests for the higher permeability inner zone (analysis figure not shown). For the outer lower permeability zone estimates of $\mathrm{K}$ ranged between 3.80 and $4.23 \mathrm{~m} /$ day (average $4.02 \mathrm{~m} /$ day). Results obtained from the Bouwer and Rice method are generally less definitive for tests exhibiting heterogeneous formation response behavior. However for these tests, the Bouwer and Rice method produced comparable K estimates as the type-curve method for the inner and outer permeability zones. For the Bouwer and Rice method estimates of $\mathrm{K}$ for the high permeability (inner) zone ranged 

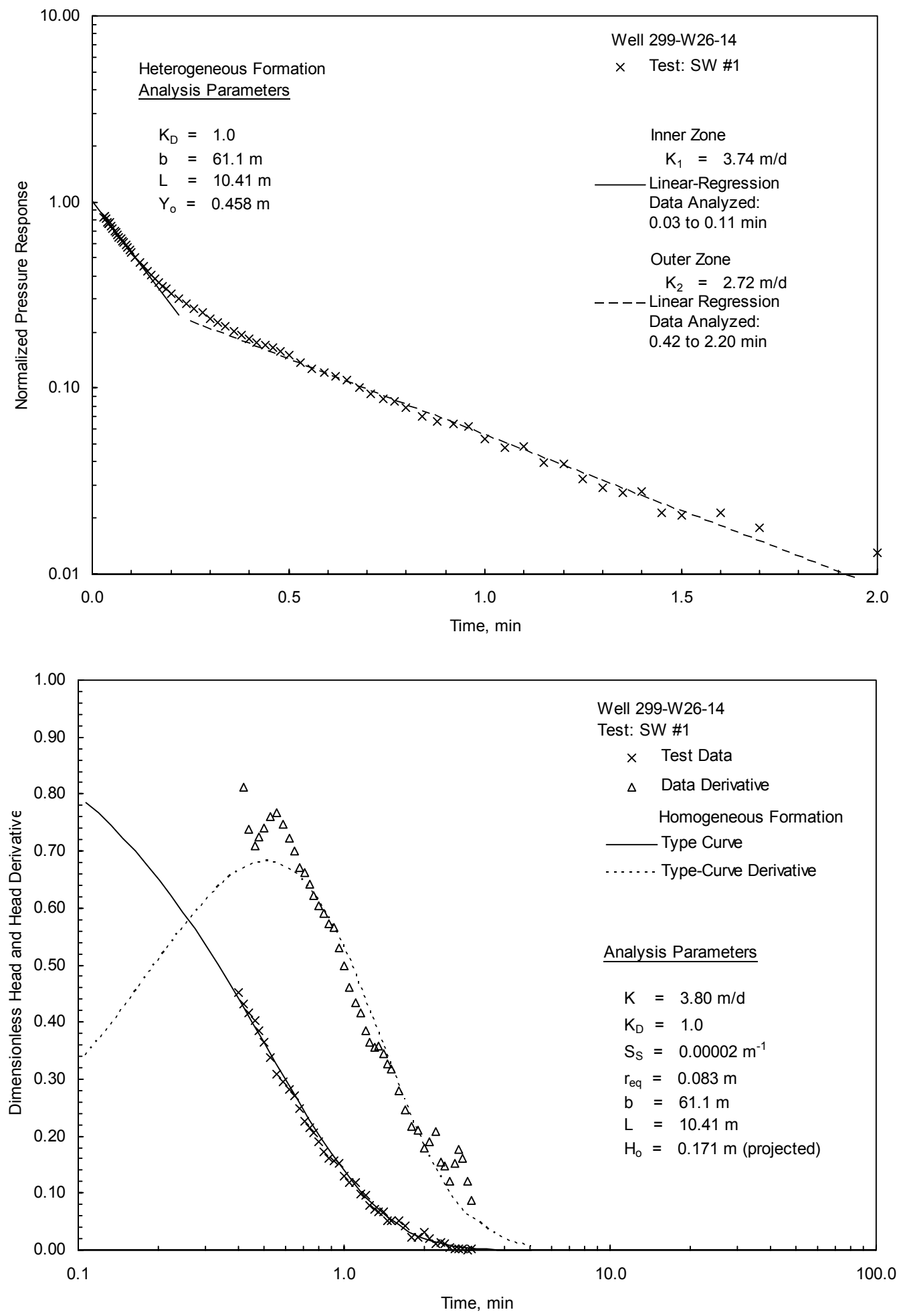

Figure 4.2. $\quad$ Selected Slug-Test Analysis Plots for Well 299-W26-14 (Bouwer and Rice method [top] and type-curve method [bottom]) 
between 2.81 and $3.74 \mathrm{~m} /$ day (average $3.28 \mathrm{~m} /$ day) for both stress-level tests. For the outer lower permeability zone, estimates of $\mathrm{K}$ ranged between 2.72 and $3.30 \mathrm{~m} /$ day (average $3.01 \mathrm{~m} /$ day). Selected examples of the analysis plots for this well are shown in Figure 4.2. As noted in Chapter 3.1.3, the inner zone results are believed to be not representative of actual in situ formation conditions and may be attributable to a number of artificially imposed conditions (e.g., over well-development, high permeability sandpack installation). For these reasons, only the outer zone analysis results should be used for assessing aquifer formation characteristics at this well location.

\subsection{Well 299-E24-22}

A total of four standard slug tests (two low and two high stress) were conducted on October 8, 2003. All slug tests exhibited under-damped (oscillatory behavior), which is indicative of high permeability aquifer conditions. Slug tests exhibiting this type of response behavior cannot be analyzed using standard, over-damped-response based analytical methods (i.e., using either the Bouwer and Rice Chapter 3.1.1.1 or type-curve - Chapter 3.1.1.2). The High-K analysis method presented in Butler and Garnett (2000) and Butler et al. (2003) (see Chapter 3.1.4) was used to analyze the slug tests at well 299-E24-22 that exhibit high permeability response characteristics.

Because of the existing high permeability test interval conditions, very small test responses were observed for the low stress tests (test response $<0.07 \mathrm{~m}$, with recovery $<10$ seconds). Due to the larger test responses produced, better analytical results were obtained for the high stress tests. A High-K analysis plot for a selected test at this well is shown in Figure 4.3. As indicated, an under-damped

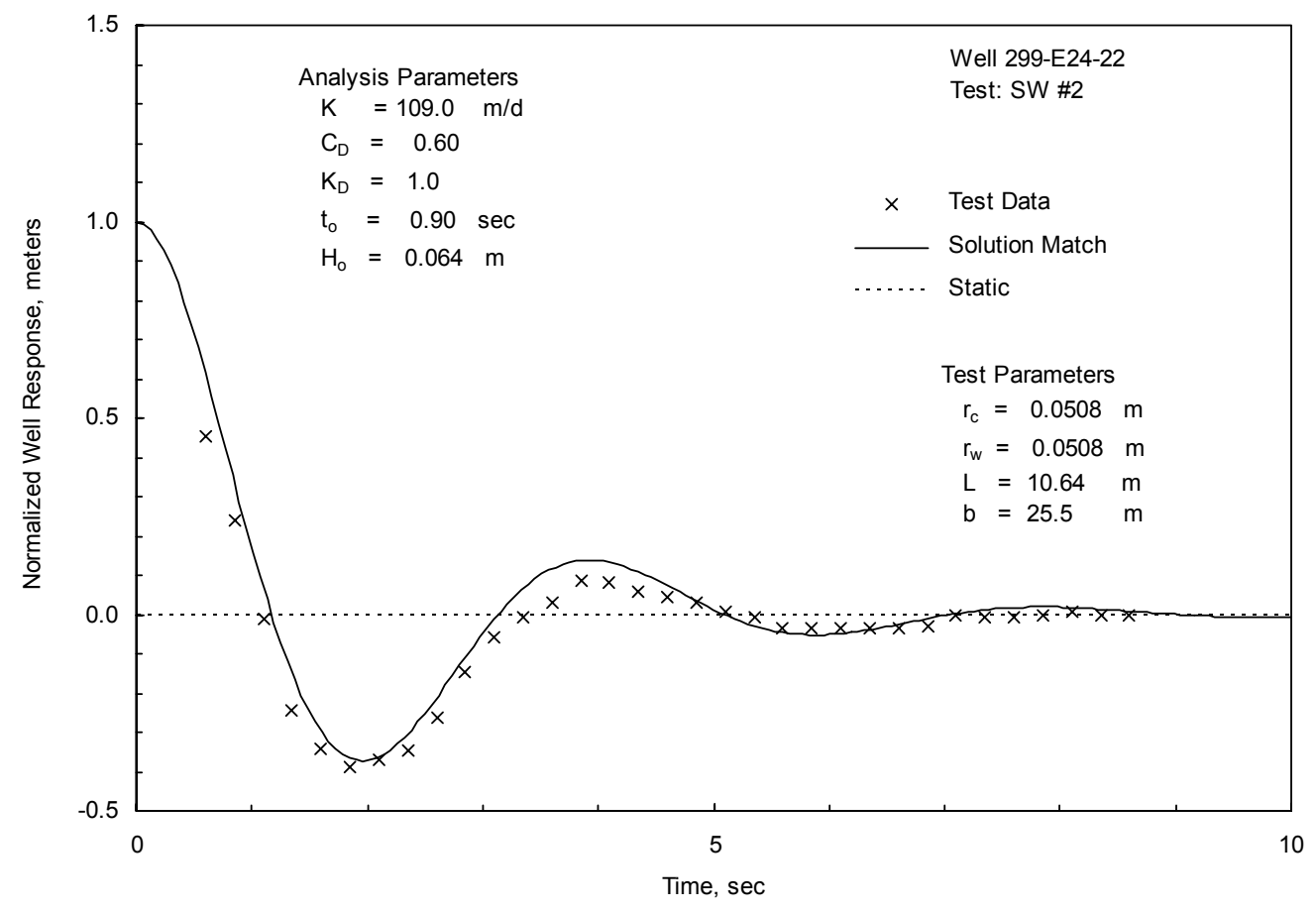

Figure 4.3. High-K, Under-Damped Slug-Test Analysis Plot for Well 299-E24-22 
(oscillatory) response is exhibited with a rapidly damped recovery to static conditions (i.e., recovery within $\sim 10$ seconds). Very similar response characteristics were exhibited for the other high and lowstress tests.

Because the under-damped test responses were very similar, results obtained from the High-K analysis method are quite comparable for all tests. Estimates for K ranged between 85.8 and $92.9 \mathrm{~m} /$ day, and averaged $89.4 \mathrm{~m} /$ day for the two high stress tests. A slightly larger range was indicated for the low stress tests, with K ranging between 86.8 and $109 \mathrm{~m} /$ day, and averaging $97.9 \mathrm{~m} /$ day.

\subsection{Well 299-E25-93}

A total of four slug tests (three high and one low stress) were conducted on October 9, 2003. All slug-test responses indicated rapid recoveries ( $90 \%$ recovery within $\sim 3$ seconds) were exhibited for all tests, and are indicative of high permeability conditions. Because of the existing high permeability test interval conditions, very small test responses exhibited during the initial low stress test, no additional lowstress tests were conducted. As a result, the hydraulic property estimates obtained for this site were derived solely from the high-stress test results.

A comparison of the normalized, high-stress slug-test responses indicates nearly identical behavior, which suggests that the well had been fully developed. Examination of the individual slug-test responses also indicates a nonlinear (concave downward), critically-damped slug test response. Slug tests exhibiting this type of response behavior cannot be analyzed quantitatively with the standard, linearresponse based analytical methods (i.e., using either the Bouwer and Rice - Section 3.1.1.1 or type-curve Section 3.1.1.2). The High-K analysis method presented in Butler and Garnett (2000) (see Section 3.1.2) was used to analyze the slug tests at well 299-E25-93 that exhibit high permeability response characteristics. Because the test responses were nearly identical, results obtained from the High-K analysis method are quite comparable. Because of the rapid test recovery, the results from all the high-stress tests were combined to facilitate the analysis process. Figure 4.4 shows the results of the combined analysis of high-stress tests. An average estimate for K for the combined test plot yielded a value of $49.3 \mathrm{~m} /$ day.

\subsection{Well 299-E26-10}

A total of four slug tests (two low and two high stress) were conducted on August 19, 2003. As noted in Table 4.1, well 299-E26-10 has a small saturated well-screen/aquifer thickness (1.98 m), which is completed primarily within sediments of the Hanford formation $(\sim 1.5 \mathrm{~m})$, and intersects a small section of the underlying Elephant Mt. basalt flowtop $(\sim 0.5 \mathrm{~m})$. Rapid recoveries ( $90 \%$ recovery within 7 seconds) were exhibited for all tests, and are indicative of high permeability conditions. A comparison of the 


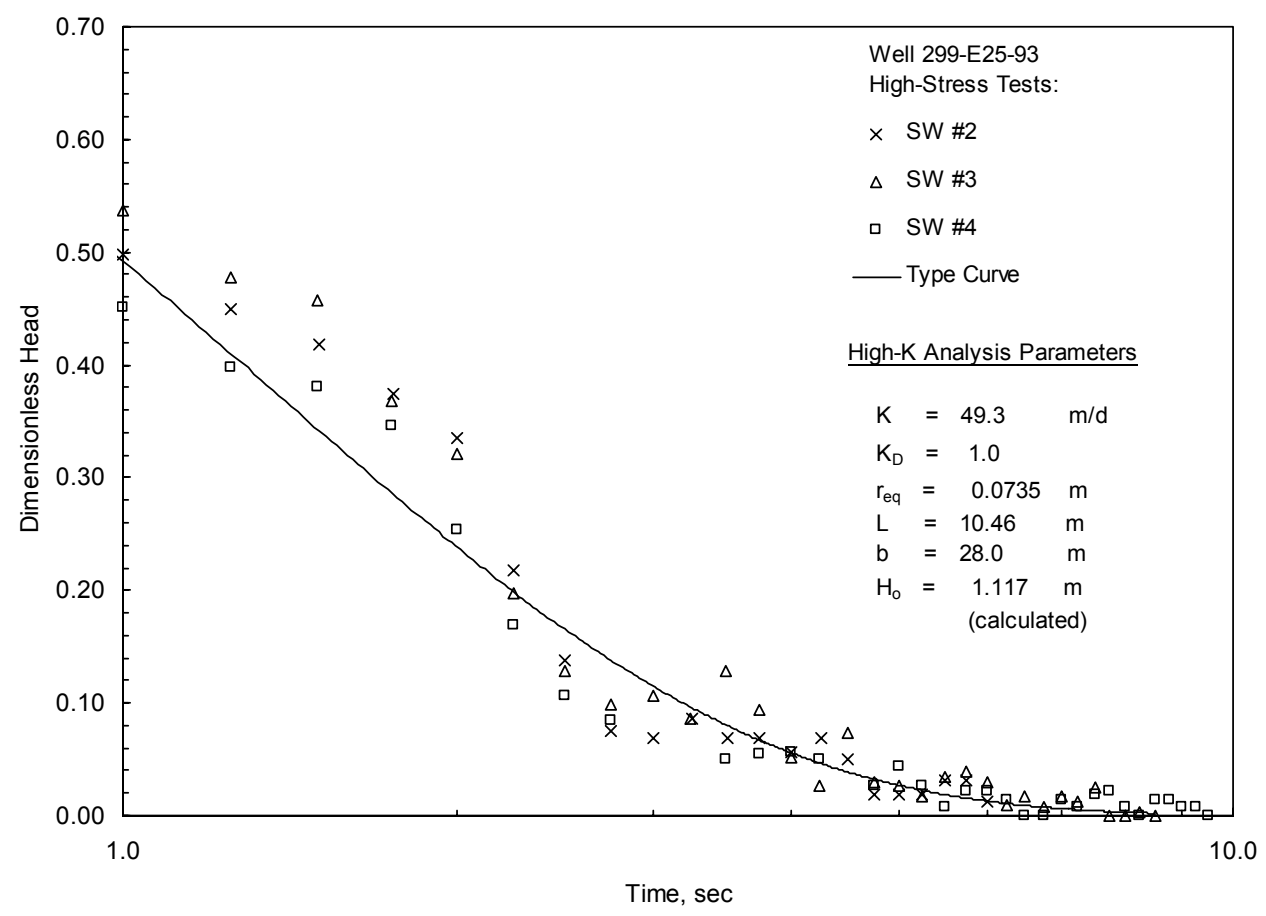

Figure 4.4. High-K, Critically-Damped Slug-Test Analysis Plot for Well 299-E25-93

normalized, high- and low-stress slug test responses indicates essentially identical behavior, which suggests that the well had been fully developed and an absence of non-linear test behavior. A comparison of $\mathrm{K}$ estimates indicates higher results ( $25 \%$ higher) were obtained for the Bouwer and Rice method. For the Bouwer and Rice method, estimates for K ranged between 47.4 and $54.7 \mathrm{~m} /$ day (average $51.1 \mathrm{~m} /$ day), while the type-curve method provided estimates between 36.7 and $42.8 \mathrm{~m} /$ day (average $39.8 \mathrm{~m} /$ day) for both stress-level tests. Selected examples of the analysis plots for this well are shown in Figure 4.5.

In addition to the current testing, well 299-E26-10 was also previously slug tested (two slug withdrawal tests) shortly after well construction in August 1990 (Sweeney 1993). At the time of this earlier testing, the unconfined aquifer thickness was $\sim 4.1 \mathrm{~m}$, with the water table extending an additional $2.1 \mathrm{~m}$ above the FY 2003 slug test/water-table condition. Because of the extremely rapid recovery responses (e.g., recovery within 3 seconds), no estimates of hydraulic conductivity were reported for these earlier tests. The recovery times exhibited during testing in 1990, however, are consistent with test response characteristics exhibited during testing in 2003, when accounting for differences in aquifer thickness. 

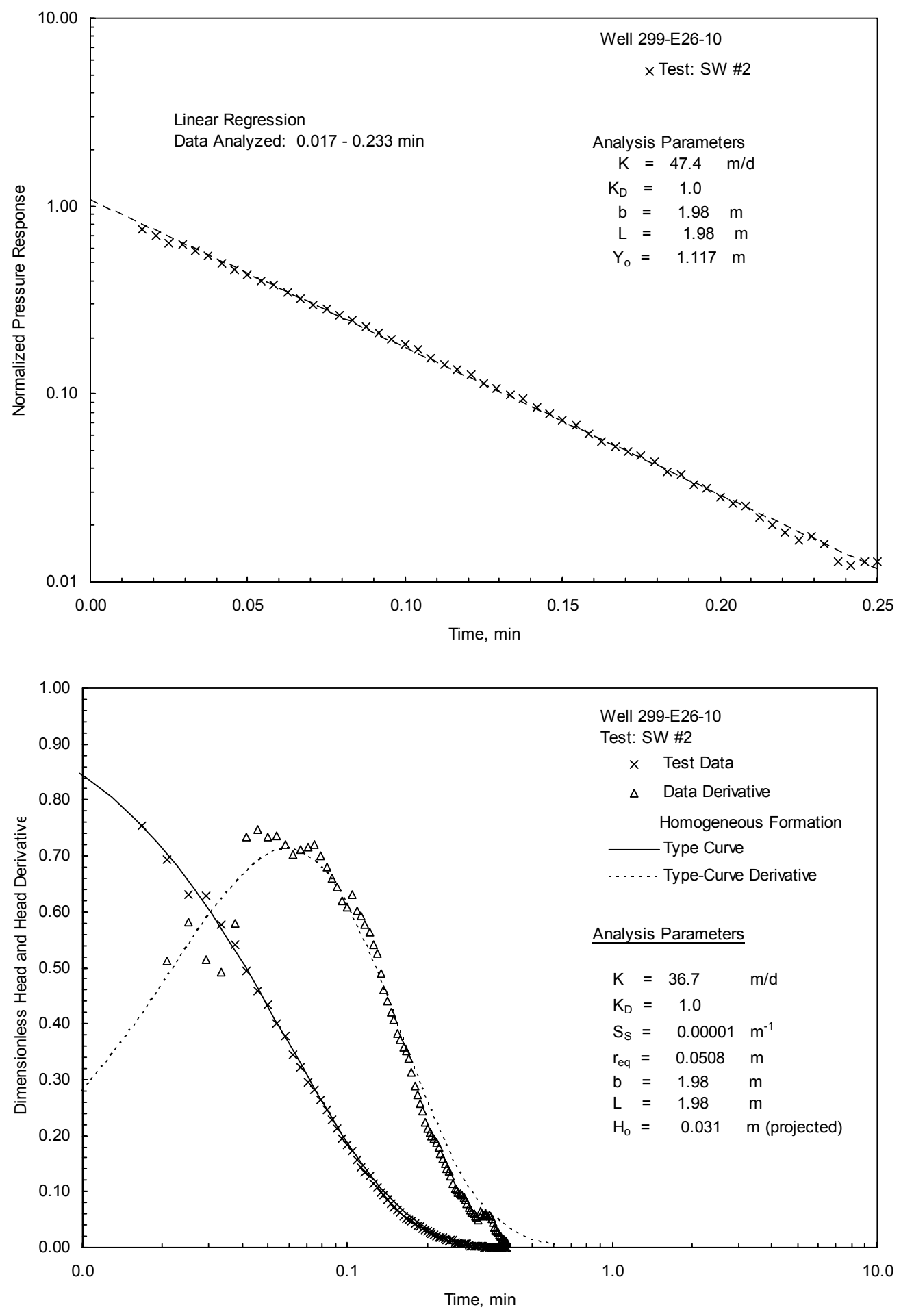

Figure 4.5. Selected Slug-Test Analysis Plots for Well 299-E26-10 (Bouwer and Rice method [top] and type-curve method [bottom)]) 


\subsection{Well 299-E26-11}

A total of five slug tests (three low and two high stress) were conducted on August 20, 2003. As noted in Table 4.1, well 299-E26-11 has a small well-screen $(1.7 \mathrm{~m})$, which is completed within the Elephant Mountain basalt flowtop. The water table extends an additional $1.56 \mathrm{~m}$ above the well screen into the overlying supra-sediments (i.e., Hanford formation) making a combined aquifer thickness of $3.26 \mathrm{~m}$ at the time of testing. The hydrologic property estimates derived from slug testing are attributed solely to the screened interval, i.e., the Elephant Mountain basalt flowtop.

Relatively rapid recoveries ( $90 \%$ recovery within 60 seconds) were exhibited for all tests, and are indicative of moderate permeability conditions. A comparison of the normalized, high- and low-stress slug-test responses indicates essentially identical behavior, which suggests that the well had been fully developed. Examination of the individual slug-test responses also indicates an elastic (concave upward) response displayed on the Bouwer and Rice analysis plot in Figure 4.7. The elastic response requires that late-time analysis be employed (i.e., the normalized head segment between 0.3 and 0.2 ) when using the Bouwer and Rice (1976) method, as recommended in Butler $(1996,1998)$. A comparison of K estimates indicates that slightly lower results $(\sim 15 \%$ lower) were obtained for the Bouwer and Rice method. For the Bouwer and Rice method, estimates for K ranged between 5.53 and $6.16 \mathrm{~m} /$ day (average $5.85 \mathrm{~m} /$ day), while the type-curve method provided estimates between 6.26 and $7.34 \mathrm{~m} /$ day (average $6.80 \mathrm{~m} /$ day) for both stress-level tests. Selected examples of the analysis plots for this well are shown in Figure 4.6.

In addition to the current testing, well 299-E26-11 was also previously slug tested (one slug withdrawal test) shortly after well construction in August 1990 (Sweeney 1993). At the time of this earlier testing, the water table extended an additional $3.17 \mathrm{~m}$ above the well screen into the overlying supra-sediments, making a combined aquifer thickness of $4.87 \mathrm{~m}$ at the time of testing. The hydraulic conductivity estimate derived from the earlier slug test is reported as $6.1 \mathrm{~m} /$ day. This earlier value falls within the average hydraulic conductivity range obtained from FY 2003 testing (5.85 to $6.80 \mathrm{~m} /$ day; Table 4.1). The close corroboration of test results obtained by tests separated by a 13 -year period indicates that (1) no degradation has occurred in well-screen conditions (i.e., hydraulic communication between well and surrounding aquifer) and (2) that attributing hydraulic properties solely to the Elephant Mountain basalt flowtop is valid (i.e., the well-screened interval), even though the aquifer thickness differed by $\sim 50 \%$ for the two test periods.

\subsection{Well 299-E27-23}

A total of three standard slug tests (one low and two high stress) were conducted on October 7, 2003. Because of the existing high permeability test interval conditions, no analyzable test responses were observed for the low stress test (test response $<0.01 \mathrm{~m}$, with recovery $<3$ seconds). As a result, no repeat low stress test was attempted, and hydraulic property estimates were based on the high-stress test results. 

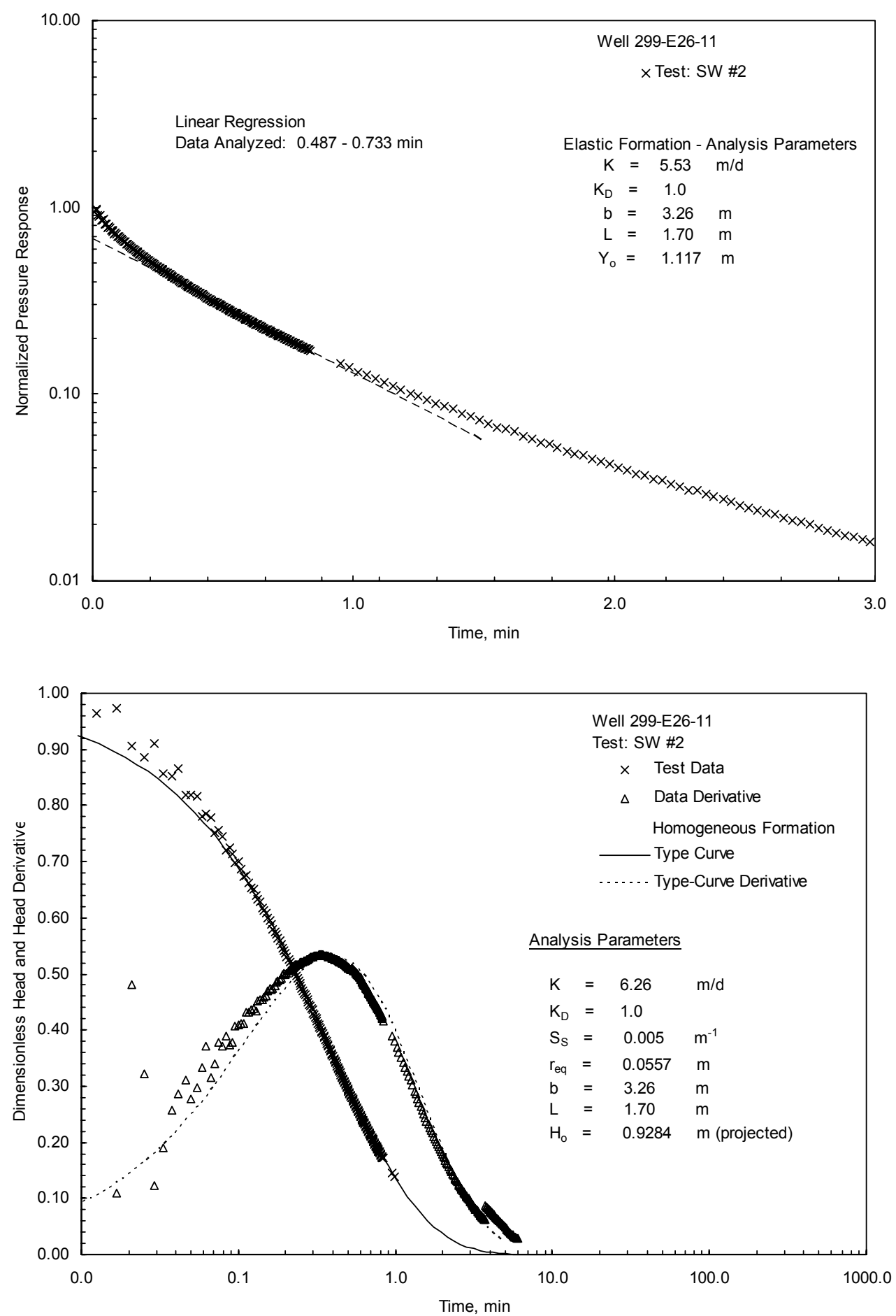

Figure 4.6. $\quad$ Selected Slug-Test Analysis Plots for Well 299-E26-11 (Bouwer and Rice method [top] and type-curve method [bottom]) 


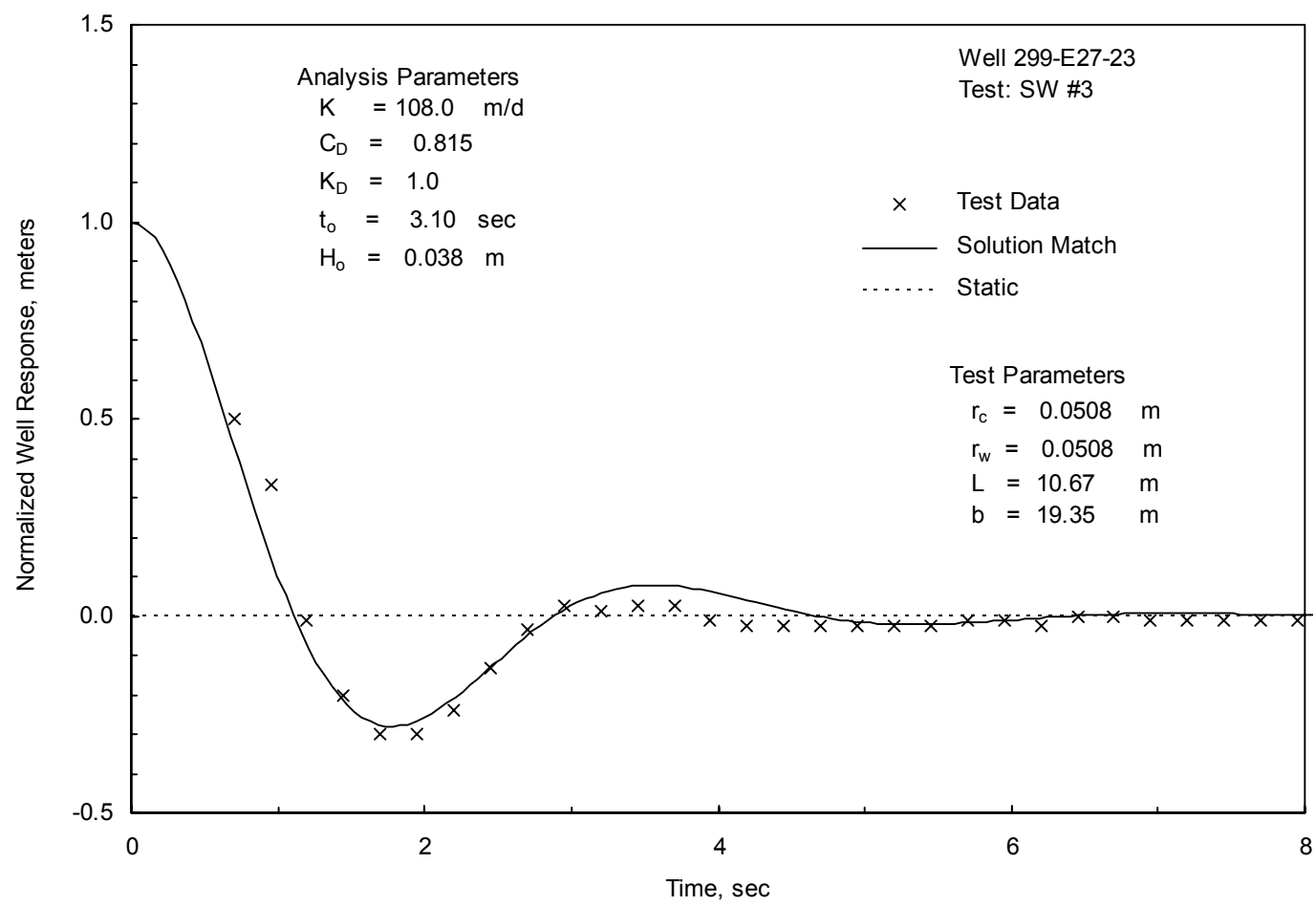

Figure 4.7. High-K, Under-Damped Slug-Test Analysis Plot for Well 299-E27-23

An example of a high-stress test analysis plot for this well is shown in Figure 4.7. Under-damped (oscillatory) responses that rapidly recover to static conditions (i.e., recovery within $\sim 7$ seconds) were exhibited for both tests. The under-damped behavior and rapid recovery are indicative of high permeability conditions. Slug tests exhibiting this type of response behavior cannot be analyzed using standard, over-damped-response based analytical methods (i.e., using either the Bouwer and Rice - Section 3.1.1.1 or type-curve - Section 3.1.1.2). The High-K analysis method presented in Butler and Garnett (2000) and Butler et al. (2003) (see Section 3.1.2) was used to analyze the slug tests at well 299-E27-23 that exhibit these high permeability response characteristics. Because the under-damped test responses were very similar, results obtained from the High-K analysis method are quite comparable. Estimates for $\mathrm{K}$ ranged between 100 and $108 \mathrm{~m} /$ day, and averaged $104 \mathrm{~m} /$ day for the two tests. 


\subsection{Tracer-Dilution Test Results}

Well 299-E26-10 was selected for detailed tracer test characterization during FY 2003. Results from the tracer-dilution phase of the single-well tracer testing were analyzed using the methods described in Section 3.2.1. The existing aquifer test site conditions may impact the results of the tracer-dilution test. These conditions include: presence of two hydrogeologic units within the well-screen section (i.e., Elephant Mountain flowtop and Hanford formation sediments); very small aquifer thickness (i.e., thickness, $b$, variations in surrounding region); low-hydraulic gradient causing increased importance of molecular diffusion; and possible proximity to hydrologic aquifer boundary. These identified aquifer test conditions may not meet some of the analytical assumptions expressed in Section 3.2.1. Because of these test complexities, the estimates derived from the tracer-dilution test for in-well groundwater-flow velocity, $\mathrm{v}_{\mathrm{w}}$, may have a high degree of uncertainty. Future efforts will be directed to improve the estimates of $\mathrm{v}_{\mathrm{w}}$ for tests conducted in thin aquifers having low-hydraulic gradient conditions. A description of the information pertinent to the tracer-pumpback test performed at well 299-E26-10 is provided below.

\subsection{Well 299-E26-10}

A single well tracer-dilution test was initiated on September 16, 2003 (1,000 hour, PDT) by administering 1.1 L of tracer solution (containing $3.019 \mathrm{~g}$ of bromide) within the $1.98 \mathrm{~m}$ saturated wellscreen section ( 61.15 to $63.13 \mathrm{~m}$ below brass cap). The tracer was introduced into the well using a 2.54-cm-diameter polypropylene tube that was open at a depth setting of $63.1 \mathrm{~m}$ below brass cap. Following tracer introduction, an equilibration time of approximately 12 minutes was observed to allow for dissipation of the displaced non-tracer water, originally within the 2.54-cm tracer tube, into the surrounding well-screen column. After the 12-minute equilibration period, the tracer tube was slowly raised out of the well water column, causing emplacement of the $1.1 \mathrm{~L}$ of prepared tracer into the well water column. The tracer tube then was lowered slowly and raised two times within the water column over a 3-minute period to mix the tracer within the well-screen section. As noted in Spane et al. (2001b, 2002), this method of tracer mixing provides a low-stress means of dispersing the administered tracer within the well-screen section. The designed bromide concentration within the well screen following mixing of the added tracer was $\sim 190 \mathrm{mg} / \mathrm{L}$.

Following mixing of the tracer solution, an assembly of three bromide probe sensors spaced individually at a separation distance of $0.61 \mathrm{~m}$ was lowered into the well. (Note: this probe spacing is considerably less than the spacing commonly used for earlier Hanford Site tracer-dilution tests, e.g., $1.8 \mathrm{~m}$ ). Final depth settings for the three bromide probes were $62.79,62.18$, and $61.57 \mathrm{~m}$ below brass cap. (Note: bottom probe, Zone 1, is within the Elephant Mountain basalt flowtop well-screen section, while the top two probes, Zones 2 and 3, are within the Hanford formation section). Each probe had an attached plastic centralizer to keep the probe approximately centered within the well-screen section. Installation of the probe assembly was completed in $\sim 35$ minutes following the mixing of the tracer within the well screen. The bromide concentration within the borehole following emplacement and equilibration of the probes was approximately $160 \mathrm{mg} / \mathrm{L}$, however, considerable variability in tracer concentration was evident between the three probe depth settings (i.e., $\sim 80$ to $300 \mathrm{mg} / \mathrm{L}$ ). This depth variability in tracer concentration within the well-screen section persisted over the next 48-hour 
monitoring period. Because of this heterogeneity in tracer concentration and the extremely low tracerdilution rates exhibited, the tracer probes were removed from the well on September 18, 2003 (1205 PDT) and the tracer re-mixed within the well-screen section. To facilitate mixing, the bottom end of the 2.54-cm-diameter polypropylene tube originally used to administer the tracer was flared. The tracer was mixed by slowly raising and lowering the polypropylene tube ten times. Following mixing, the tracer probes were re-installed within the well screen utilizing the previous depth settings. The average bromide concentration within the well screen after $\sim 60$ minutes following tracer re-mixing and re-installation of the tracer probes was approximately $119 \mathrm{mg} / \mathrm{L}$, and varied between 70 and $162 \mathrm{mg} / \mathrm{L}$ between the three probe depth settings. Dilution of the tracer was extremely slow and is reflective of the extremely low hydraulic gradient conditions within the surrounding area. The dilution and dissipation of bromide tracer within the well screen was observed for a period of approximately 85 days (122,365 minutes). Recovery of the tracer from well 299-E26-10 and the surrounding aquifer was initiated with a constant-rate pumping test beginning on December 9, 2003 (0825 hours PST).

Visual examination of the dilution patterns for the various sensor-depth settings during the first week of tracer testing suggests a very slight, vertical, downward flow condition within the well-screen section between the top two probe depth settings, i.e., between 61.57 to $62.18 \mathrm{~m}$ below brass cap (see Section 8.1), which are within the Hanford formation well-screen section. A downward, in-well average flow velocity of $0.0002 \mathrm{~m} /$ minute, was calculated by using the arrival times of recognizable tracer signature between the two tracer sensors (Figure 5.1). A comparison of the in-well tracer-dilution patterns for the various probe depth settings also suggests that the $\sim 0.5 \mathrm{~m}$ of Elephant Mountain basalt flowtop has a considerably lower hydraulic conductivity than the overlying Hanford formation sediments.

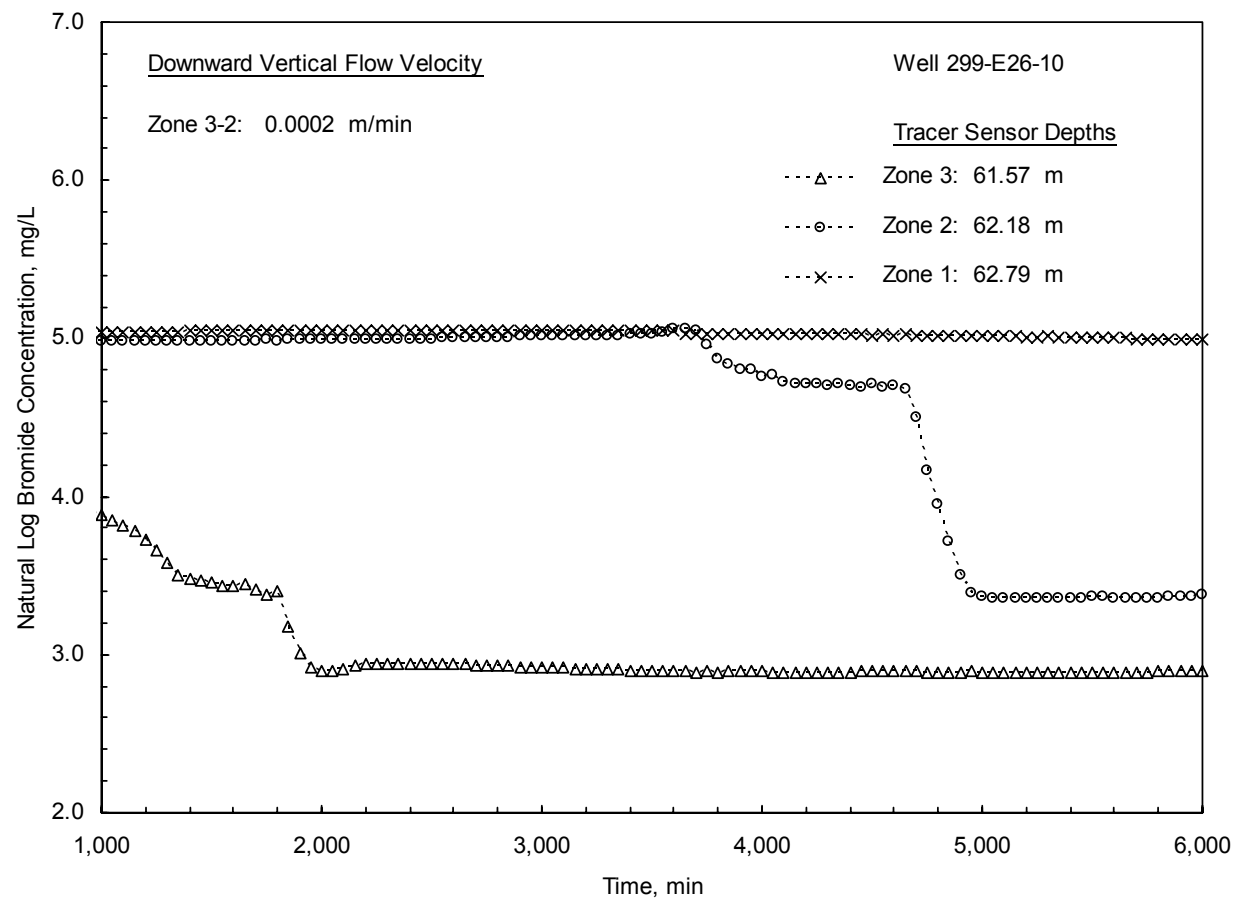

Figure 5.1. Tracer Concentration Versus Depth-Response Patterns Within Well 299-E26-10 During Tracer-Dilution Testing and Calculated In-Well Vertical Flow Velocity 
As discussed in Section 3.2.1, to be strictly valid, tracer-dilution tests require that no vertical flow conditions exist within the well and that the tracer is continually mixed within the test section. To "simulate" a continuously mixed condition, an average well-screen tracer concentration was calculated, based on averaging all three sensor-depth readings recorded with time (i.e., 61.57 to $62.79 \mathrm{~m}$ below brass cap). It is not known whether the vertical flow conditions observed within the well are significant enough to adversely affect the results of the tracer-dilution test. The analysis results, therefore, should be viewed as being qualitative estimates.

The observed, average dilution pattern versus time can be analyzed to calculate $\mathrm{v}_{\mathrm{w}}$, using Equation 3.3. Two linear dilution slopes are evident in Figure 5.2 over the protracted tracer-dilution period. The reason for the two tracer-dilution slopes is not completely understood but may be attributed to molecular diffusion effects or changes in hydraulic gradient conditions over the extended tracer-dilution period. A slightly higher dilution slope is evident during the $\sim$ first half of the test (early-time analysis) and may be reflective of both tracer-dilution and molecular diffusion effects. The lower dilution slope during the last half of the test (late-time analysis) occurs when tracer within the well screen has decreased in concentration to $<10 \mathrm{mg} / \mathrm{L}$ and may reflect the decreasing influence of tracer diffusion. Linearregression analysis of the average dilution response for both time periods indicates a slope on the natural $\log$ of concentration versus time of -0.0000388 minutes $^{-1}$ and -0.0000223 minutes $^{-1}$ for the first and second halves of the tracer-dilution period, respectively. The calculated average A/V relationship for the test interval, taking into account the presence of sensor instrumentation/cable test system cross-sectional area, is $13.435 \mathrm{~m}^{-1}$. Based on these observed and measured parameters, an average calculated $\mathrm{v}_{\mathrm{w}}$ of 0.0042 and $0.0024 \mathrm{~m} /$ day are calculated for the first and second tracer-dilution periods, respectively.

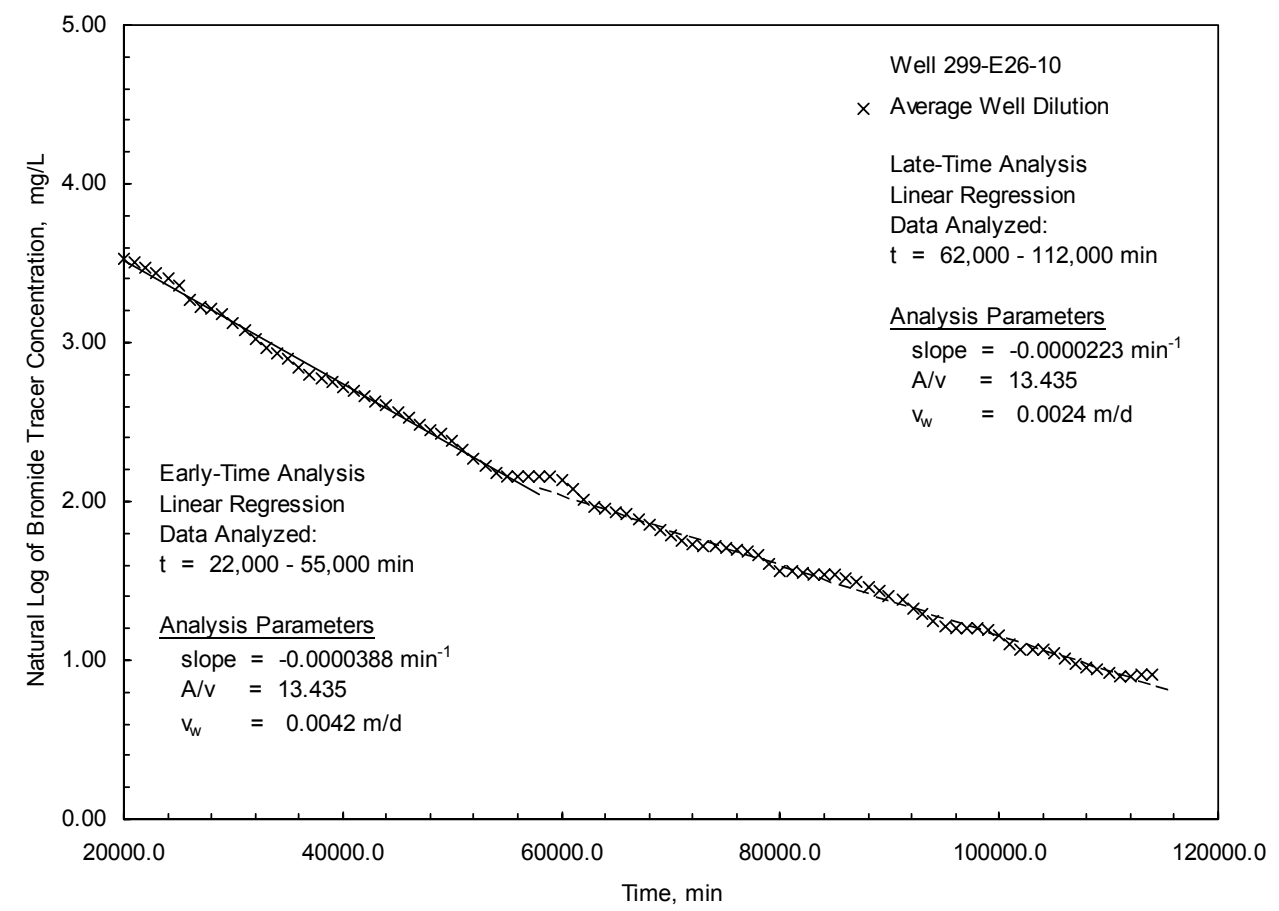

Figure 5.2. Average Tracer-Dilution Test Results Within Well 299-E26-10 


\subsection{Tracer-Pumpback Test Results}

Results from the bromide tracer-pumpback phase conducted at well 299-E26-10 were analyzed using the methods described in Section 3.2.2. As noted in Section 5.0, the existing aquifer test site conditions may impact the results of the tracer pumpback test. These conditions include: presence of two hydrogeologic units within the well-screen section; very small aquifer thickness (i.e., thickness variations in surrounding region); low-hydraulic gradient causing increased importance of molecular diffusion; and possible proximity to hydrologic aquifer boundary. These identified aquifer test conditions may not meet some of the analytical assumptions expressed in Section 3.2.2. Because of these test complexities, the estimates derived from the pumpback test for effective porosity, $\mathrm{n}_{\mathrm{e}}$, and average groundwater-flow velocity within the aquifer, $\mathrm{v}_{\mathrm{a}}$, are considered uncertain. Future efforts will be directed to improve the estimates for $\mathrm{n}_{\mathrm{e}}$ and $\mathrm{v}_{\mathrm{a}}$ for tests conducted in thin aquifers having low-hydraulic gradient conditions. A description of the information pertinent to the tracer-pumpback test performed at well 299-E26-10 is provided below.

\subsection{Well 299-E26-10}

After an approximate 85-day period (122,365 minutes) for tracer-drift, recovery of the tracer from well 299-E26-10 and the surrounding aquifer was initiated with a constant-rate pumping test beginning on December 9, 2003 (0825 hours PST). Tracer recovery was terminated after 365 minutes. The average tracer concentration within the well was $1.91 \mathrm{mg} / \mathrm{L}$ at the beginning of pumpback, based on late-time projection of the average dilution regression line (Figure 5.2) to the time of tracer pumpback initiation. Given the calculated well screen and sandpack volumes of 15.97 and $14.88 \mathrm{~L}$, respectively, $2.97 \mathrm{~g}$ of the $3.02 \mathrm{~g}$ of tracer initially emplaced in the well, are estimated to have been transported within the aquifer. After minor flow adjustments were completed during the first 2 minutes of the test, pumping rates remained relatively constant during tracer pumpback, ranging between 19.53 and $22.57 \mathrm{~L} /$ minute (average $20.17 \mathrm{~L} /$ minute) for the entire test as shown in Figure 6.1. An estimated $1.94 \mathrm{~g}$ of the total $3.02 \mathrm{~g}$ of tracer (i.e., $\sim 64 \%$ ) emplaced in the well were recovered during the constant-rate pumping test. The pumping time, $t_{p}$, to recover $50 \%$ of the tracer emplaced within the aquifer (accounting for transit time during pumping from the well screen to land surface) is estimated at 282.32 minutes. The time required to recover the center of the tracer mass that was transported within the aquifer was used in Equations 3.8 and 3.9 to calculate $\mathrm{n}_{\mathrm{e}}$ and $\mathrm{v}_{\mathrm{a}}$. As indicated in the equations, information pertaining to hydraulic conductivity, $\mathrm{K}$, hydraulic gradient, I, aquifer thickness, b, and pumping rate, $\mathrm{Q}$, must also be known for the test well site.

A K value of $36.2 \mathrm{~m} /$ day was used, which is based on results from the constant-rate pumping test for the test well (i.e., during tracer pumpback; Section 7.1). The calculated local I value of $0.00019 \mathrm{~m} / \mathrm{m}$ represents the average hydraulic gradient conditions (i.e., 1997-2003) based on trend-surface analysis for water-level elevation measurement periods for well 299-E26-10 and five nearby monitor wells 299-E26-9, -E27-10, E34-3, -E34-7, and -E35-2, as indicated in Section 8.0, Table 8.4. The b value of $1.98 \mathrm{~m}$ was calculated directly from the observed water-table elevation at the time of testing and known geologic information obtained at the test well. 


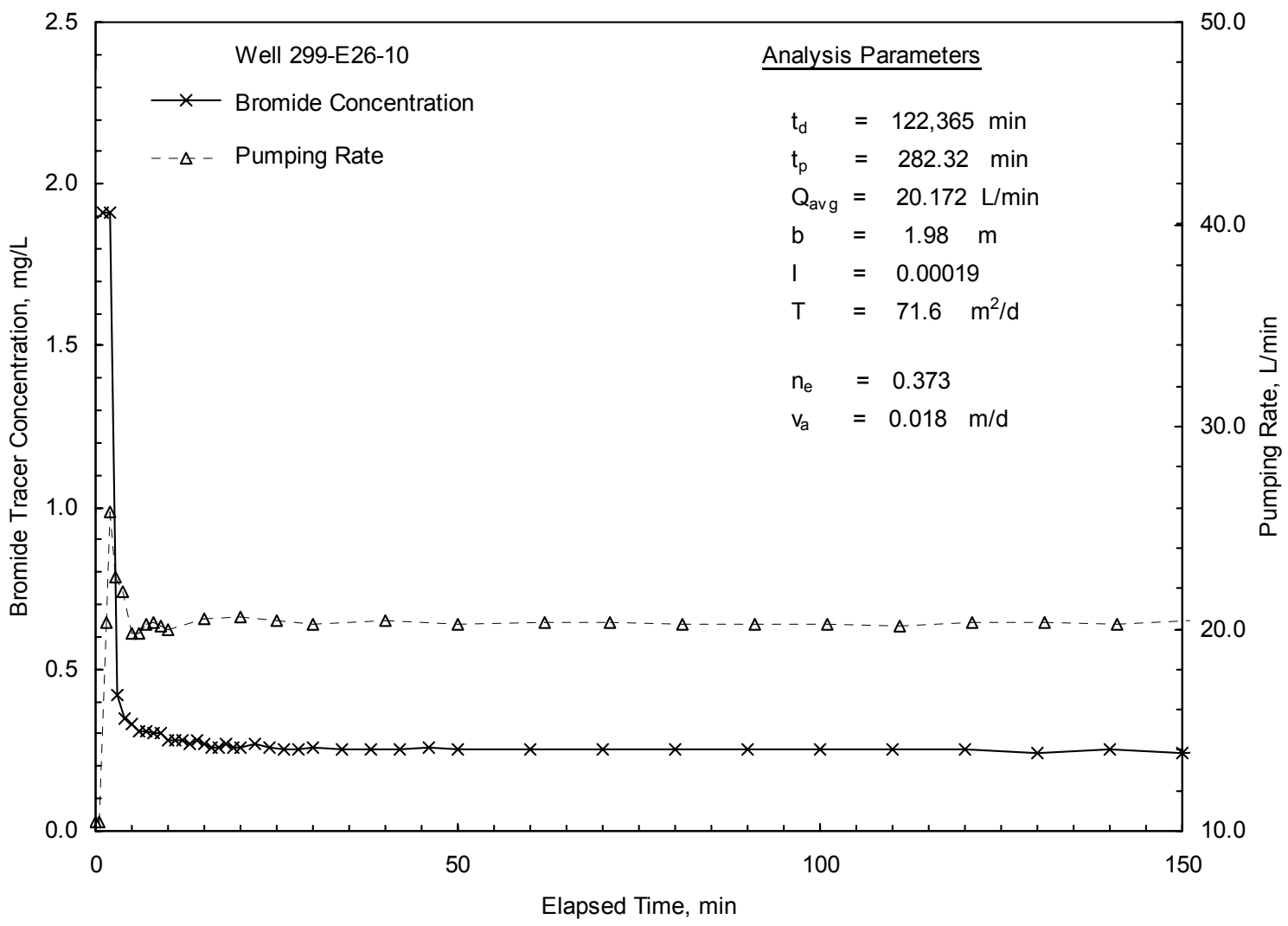

Figure 6.1. Tracer-Pumpback Test Results for Well 299-E26-10

Based on these input parameters and tracer-pumpback results, $\mathrm{n}_{\mathrm{e}}$ and $\mathrm{v}_{\mathrm{a}}$ are estimated to be 0.373 and $0.0184 \mathrm{~m} /$ day, respectively. Based on the observed tracer-pumpback profile (see Figure 6.1) and calculated radial distance traveled within the aquifer by the tracer's center of mass (i.e., product of $\mathrm{v}_{\mathrm{a}}$ and $\mathrm{t}_{\mathrm{d}}=$ $1.6 \mathrm{~m}$ ), the results of pumpback reflect local, near-well, aquifer conditions and may be susceptible to the adverse wellbore effects discussed in Section 3.2.2. In addition, because of the extended length of the tracer drift period, tracer-diffusion effects not accounted for in the analysis method may make the estimated values for $n_{e}$ and $v_{a}$ from the tracer-pumpback test questionable. Table 6.1 summarizes the pertinent information associated with the tracer-pumpback results for well 299-E26-10. 
Table 6.1. Tracer-Pumpback Test Summary for Well 299-E26-10

\begin{tabular}{|c|c|c|c|c|c|c|c|c|c|}
\hline \multirow[b]{2}{*}{$\begin{array}{c}\text { Waste } \\
\text { Management } \\
\text { Area }\end{array}$} & \multirow[b]{2}{*}{ Well } & \multicolumn{4}{|c|}{ Hydrologic Characterization Data } & \multicolumn{4}{|c|}{ Tracer-Pumpback Test } \\
\hline & & \begin{tabular}{|c} 
Aquifer \\
Thickness, \\
b (m)
\end{tabular} & $\begin{array}{c}\text { Pumping } \\
\text { Rate, Q } \\
\text { (liters/min) }\end{array}$ & $\begin{array}{c}\text { Hydraulic } \\
\text { Gradient, I } \\
(\mathrm{m} / \mathrm{m})\end{array}$ & $\begin{array}{c}\text { Hydraulic } \\
\text { Conductivity, K } \\
\text { (m/day) }\end{array}$ & $\begin{array}{c}\text { Tracer } \\
\text { Drift } \\
\text { Time, } t_{d} \\
(\text { min })\end{array}$ & $\begin{array}{c}\text { Tracer } \\
\text { Recovery } \\
\text { Time, } \mathrm{t}_{\mathrm{p}} \\
(\mathrm{min})\end{array}$ & $\begin{array}{c}\text { Effective } \\
\text { Porosity, } \\
n_{\mathrm{e}}\end{array}$ & $\begin{array}{c}\text { Groundwater- } \\
\text { Flow } \\
\text { Velocity, } \\
\mathrm{v}_{\mathrm{a}}(\mathrm{m} / \text { day })\end{array}$ \\
\hline $\operatorname{LERF}^{(a)}$ & 299-E26-10 & 1.98 & 20.172 & 0.00019 & 36.2 & 122,365 & 282.32 & 0.373 & 0.0184 \\
\hline
\end{tabular}




\subsection{Constant-Rate Pumping Test Results}

Only one well site was selected for detailed hydrologic characterization during FY 2003. As part of the detailed hydrologic characterization, a constant-rate pumping test was conducted and extended during the tracer-pumpback following performance of the tracer-dilution test. Analysis of the resulting drawdown and recovery test data at the pumped well provides intermediate-scale estimates for transmissivity $(\mathrm{T})$, hydraulic conductivity $(\mathrm{K})$, vertical anisotropy $\left(\mathrm{K}_{\mathrm{D}}\right)$, storativity $(\mathrm{S})$ and specific yield $\left(\mathrm{S}_{\mathrm{y}}\right)$.

Barometric responses at the pumped well were monitored over a baseline period immediately prior to or following termination to tracer-pumpback, when other hydraulic stresses were minimal. These baseline water-level data were analyzed to assess the effects of barometric pressure fluctuations on well waterlevel responses and remove barometric fluctuations from water levels recorded during the constant-rate pumping test, as discussed in Section 3.3.2. Derivative techniques (see Section 3.3.3) were applied diagnostically to identify aquifer conditions and select the appropriate analysis method. Combined typecurve analysis of both the test responses and the derivative plots was then used to calculate hydraulic properties. The type-curves were generated using the WTAQ3 computer program (Moench 1997) and account for a wide range of test and aquifer conditions including partial penetration, vertical anisotropy, wellbore storage, unconfined aquifer drainage, and well-skin effects. A more detailed description of the various components of the constant-rate pumping-test analysis is provided in Section 3.2.

A description of the performance and analysis of the constant-rate pumping test is provided below and a summary of results is presented in Table 7.1. The estimate for $\mathrm{K}$ was calculated by dividing $\mathrm{T}$ by the total aquifer thickness, $\mathrm{b}$, which for this test was equivalent to the saturated well-screen section at the pumping well (i.e., $1.98 \mathrm{~m}$ ). Estimates of $\mathrm{S}$ and $\mathrm{K}_{\mathrm{D}}$ resulting from this test are considered less reliable than the estimates of $\mathrm{T}, \mathrm{K}$, and $\mathrm{S}_{\mathrm{y}}$, because of the lack of analyzable observation well data. Responses at a fully penetrating pumping well are much less sensitive to aquifer elastic storage and vertical anisotropy conditions, and these parameter estimates may also be adversely affected by near-well heterogeneity.

Table 7.1. Constant-Rate Pumping Test Summary

\begin{tabular}{||c|c|c|c|c|c|c||}
\hline \multirow{2}{*}{$\begin{array}{c}\text { Pumping } \\
\text { Well }\end{array}$} & Well Analyzed & $\begin{array}{c}\text { Transmissivity, } \\
\mathrm{T}, \mathrm{m}^{2} / \mathrm{day}\end{array}$ & $\begin{array}{c}\text { Horizontal } \\
\text { Hydraulic } \\
\text { Conductivity, } \\
\mathrm{K}_{\mathrm{h}}, \mathrm{m} / \mathrm{day}\end{array}$ & $\begin{array}{c}\text { Vertical } \\
\text { Anisotropy, } \\
\mathrm{K}_{\mathrm{D}}\end{array}$ & $\begin{array}{c}\text { Storativity, } \\
\mathrm{S}\end{array}$ & $\begin{array}{c}\text { Specific } \\
\text { Yield, } \\
\mathrm{S}_{\mathrm{y}}\end{array}$ \\
\hline \hline 299-E26-10 & $299-\mathrm{E} 26-10$ & 71.6 & 36.2 & 0.1 & 0.001 & 0.128 \\
\hline
\end{tabular}

\subsection{Well 299-E26-10}

At the time of testing, the well screen at well 299-E26-10 penetrated the entire unconfined aquifer, which at this location is only $1.98 \mathrm{~m}$ thick. The saturated well-screen section intersects deposits of the Hanford formation and includes a small interval $(\sim 0.5 \mathrm{~m})$ of the underlying Elephant Mountain flowtop. For test characterization purposes, the hydraulic properties determined from the constant-rate pumping test are attributed to the assumed higher permeability Hanford formation. No nearby monitor wells were available for observation well purposes during the constant-rate pumping test. The constant-rate 
discharge test was conducted from 8:25 to 14:30 Pacific standard time on December 9, 2003. Average flow rate during the test was $20.172 \mathrm{~L} /$ minute over the 365 -minute pumping period. Flow rates varied between 11 and $26 \mathrm{~L} / \mathrm{min}$ during the initial three minutes of the test as a result of manual flow regulation adjustments. Slight flow variations were also exhibited during the latter 2 hours of the test, which may be attributed to test equipment conditions (e.g., variation in power supply output to the electrical submersible pump used in the test).

Barometric responses were monitored for a 15-day period prior to initiation of the constant-rate test and for approximately 7-days following termination of pumping at the test well. The multiple-regression deconvolution technique (Rasmussen and Crawford 1997; Spane 1999) was used to remove barometric pressure effects from the water levels measured during the test, as discussed in Section 3.3.2. A total lag time of 12 hours provided the best match of well water-levels associated with barometric responses during the baseline monitoring periods.

Figure 7.1 shows a diagnostic log-log plot of the barometric corrected drawdown data for pumping well 299-E26-10, and a type-curve match of the drawdown data and drawdown derivative. The data were also adjusted for unconfined aquifer dewatering following the procedure in Section 3.3. These adjustments are small for the drawdown magnitude observed at the test well site; however, for thin aquifer conditions, they are of importance and should be corrected for. As shown in Figure 7.1, the effect of pumping rate adjustments is readily evident during the first 3 minutes of the test. In addition, slight

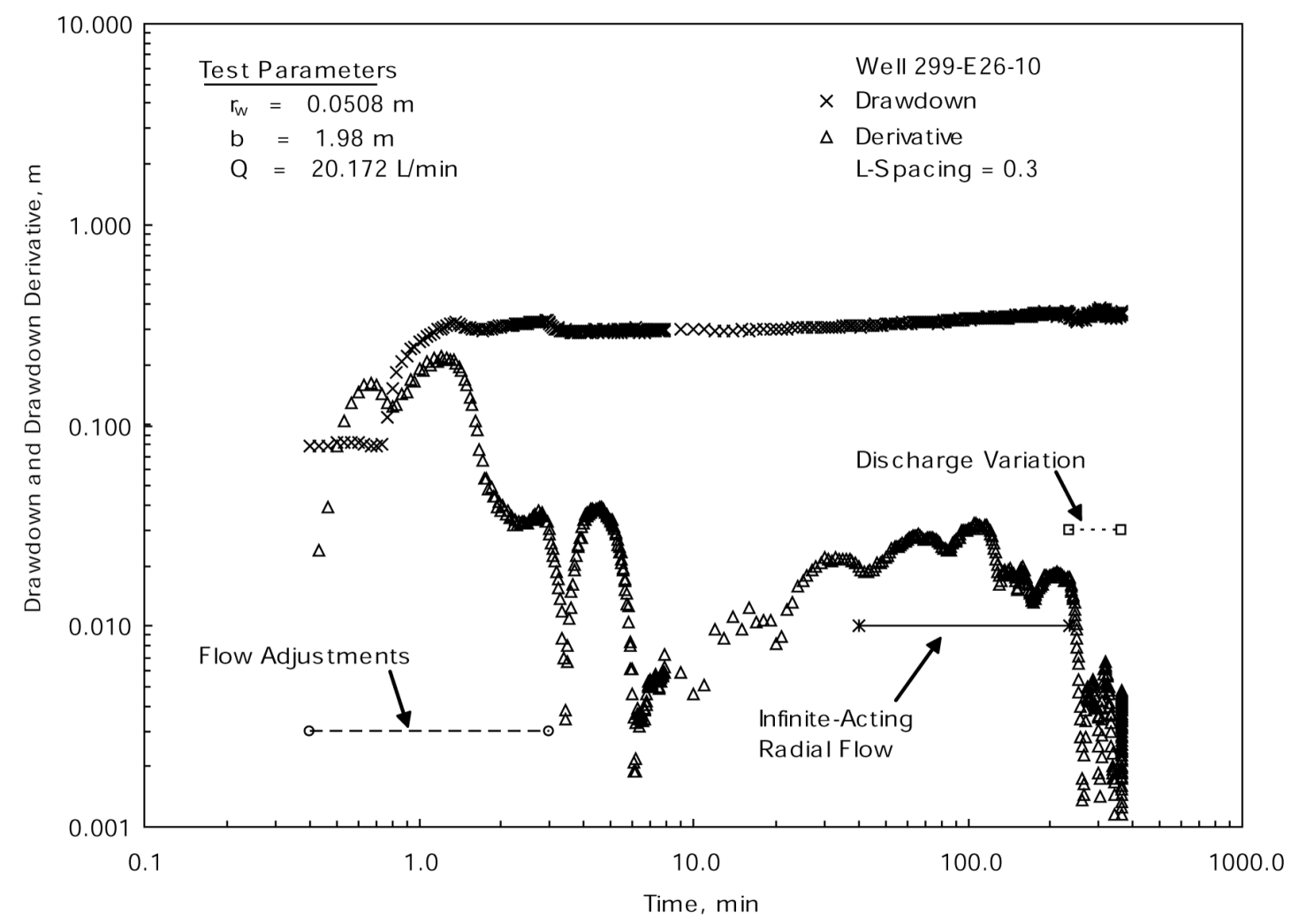

Figure 7.1. Diagnostic Plot Analysis of Drawdown Test Data for Pumping Well 299-E26-10 
changes in pumping rate also occurred during the last 2 hours of the drawdown test, which affected latetime test drawdown. Because of the dependence of drawdown analytical methods on late-time test data, drawdown collected during the last 2 hours of the test were not included in the test analysis plot, due to their effect on late-time data analysis. No hydrologic boundaries were detected during the course of the pumping test, indicating a relatively homogenous, continuous aquifer within the area of influence imposed by the pumping test.

Examination of Figure 7.1 indicates that infinite-acting radial flow conditions were established approximately 50 minutes into testing. This rather rapid transition into infinite-acting conditions is a function of the small aquifer thickness, relatively high aquifer permeability, and fully penetrating well conditions. Test data reflective of infinite-aquifer response characteristics can be analyzed with semi-log, straight-line solutions, as discussed in Section 3.2.6. Figure 7.2 shows the analysis results utilizing the straight-line analysis method. As noted above, drawdown data during the last 2 hours of the test were not included in the analysis due to discharge fluctuations that occurred. The straight-line analysis provided the following estimated results: $\mathrm{T}=71.6 \mathrm{~m}^{2} /$ day, $\mathrm{K}=36.2 \mathrm{~m} / \mathrm{d}$, and $\mathrm{S}_{\mathrm{y}}=0.128$. The $\mathrm{K}$ value of $36.2 \mathrm{~m} /$ day was calculated by dividing $\mathrm{T}$ by the initial aquifer thickness, $\mathrm{b}$, which at the time of testing was $1.98 \mathrm{~m}$.

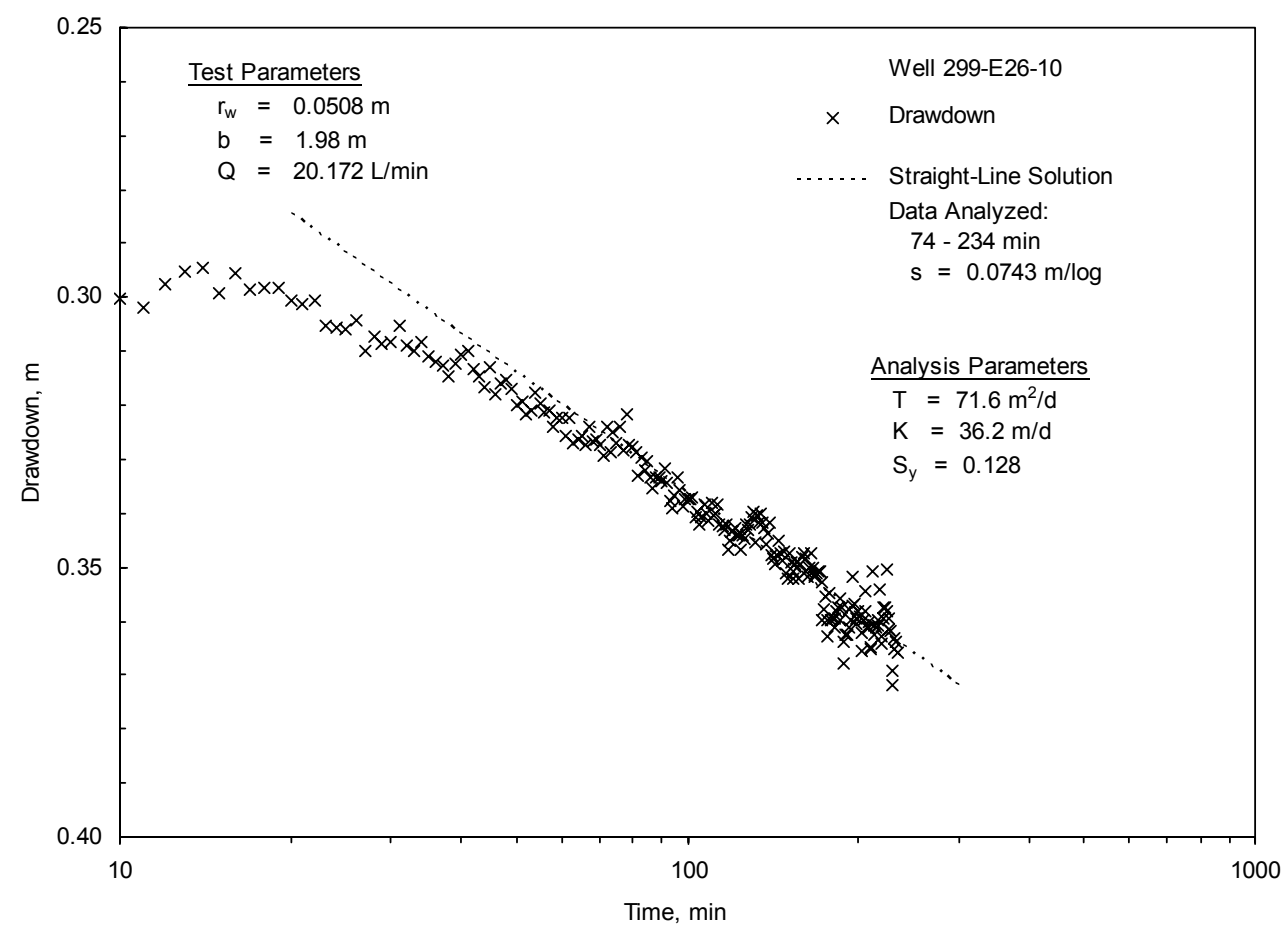

Figure 7.2. Straight-Line Analysis of Drawdown Test Data for Pumping Well 299-E26-10 
To examine the relative goodness-of-fit of these estimates on the overall drawdown response, the calculated parameters from the straight-line analysis were used in WTAQ3 (Section 3.3.6) to calculate an appropriate drawdown response over the entire pumping period. Figure 7.3 shows a log-log comparison plot of the observed and calculated drawdown and drawdown derivative. As shown, a very close match was achieved using the previously calculated values for $T$ and $S_{y}$, and using a value for $S$ and $K_{D}$ of 0.001 and 0.1 , respectively. The solution is particularly insensitive to $\mathrm{K}_{\mathrm{D}}$ due to the fully penetrating well conditions. As noted previously, data collected during the last 2 hours were not included in the analysis (due to adverse discharge variation), and a derivative L-spacing of 0.5 was used to smooth variability in the derivative plot (i.e., in comparison to a L-spacing $=0.3$ used in the diagnostic plot, Figure 7.1).

Observed recovery data following termination of the pumping test exhibited an anomalous rapid recovery to pre-test conditions (not shown). The exhibited rapid recovery is believed attributed to a faulty check valve within the submersible pump, which allowed pumped water within the delivery tubing string to land surface to re-enter (recharge) the well following pumping termination. As a result, recovery test data were not subjected to test analysis.

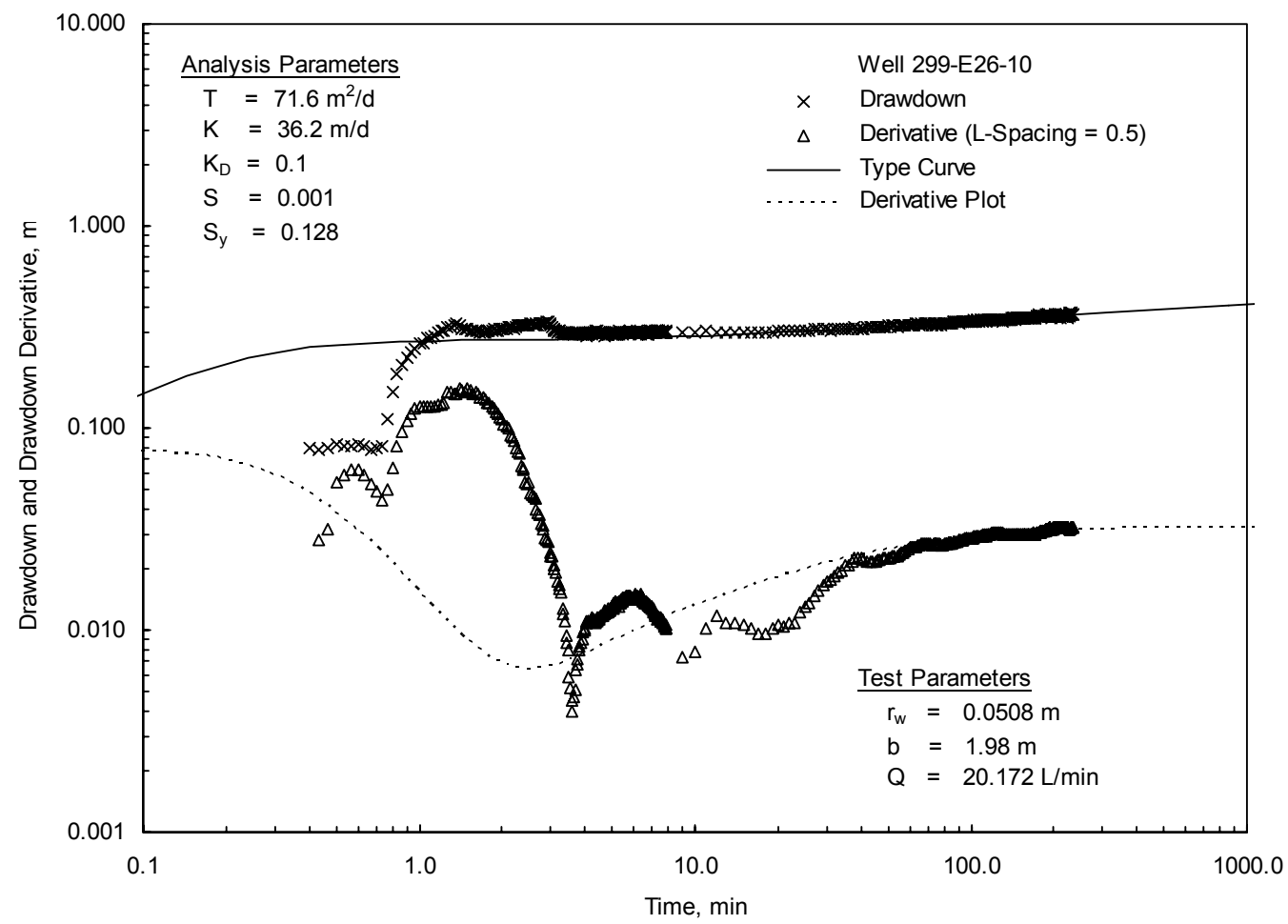

Figure 7.3. Type-Curve and Derivative Plot Analysis of Drawdown Test Data for Pumping Well 299-E26-10 


\subsection{Groundwater-Flow Characterization Results}

This chapter discusses the results pertaining to groundwater-flow direction and hydraulic gradient conditions within the general LERF area surrounding well 299-E26-10, which was selected for detailed tracer-dilution and pumpback testing. Hydraulic gradient information is used directly in analyzing tracer pumpback data, for calculating aquifer effective porosity, $\mathrm{n}_{\mathrm{e}}$, and groundwater-flow velocity, $\mathrm{v}_{\mathrm{a}}$. When used together with groundwater-flow direction estimates, this provides the basic information for assessing potential contaminant transport within and surrounding the site.

In an initial effort to assess groundwater-flow direction and hydraulic gradient conditions within the area surrounding well 299-E26-10 and within the general LERF facility, standard trend-surface-fitting methods were utilized as described in Spane (1999). Groundwater-flow direction and hydraulic gradient were calculated using the commercially available WATER-VEL (In-Situ, Inc. 1991) software program. Water-level elevations from neighboring, representative monitor wells were used as input to the WATERVEL program to calculate groundwater-flow direction and hydraulic gradient conditions over a protracted period prior to conducting the detailed tracer characterization period. The program uses a linear, twodimensional trend surface (least squares) to randomly located hydrologic head or water-level elevation input data. This method is similar also to the linear approximation technique described by Abriola and Pinder (1982) and Kelly and Bogardi (1989). Reports that demonstrate the use of the WATER-VEL program for calculation of groundwater-flow velocity and direction on the Hanford Site include Gilmore et al. (1992), Spane (1999), and Spane et al. (2001a, 2001b, 2002).

To characterize previous and current groundwater-flow conditions (i.e., flow direction and hydraulic gradient) within the general LERF study area surrounding well 299-E26-10, water-level measurements from monitoring wells were evaluated to assess whether similar dynamic well responses were exhibited. Figure 8.1 shows the locations and Table 8.1 lists pertinent information pertaining to surrounding monitoring wells having historical water-level data examined in this. A review of well completion and current monitoring conditions for the wells indicates that all the monitoring wells evaluated are completed in an extremely thin unconfined aquifer that comprises a saturated thickness of $\leq 3 \mathrm{~m}$ within LERF and its immediate vicinity. Some of the monitor wells have become dry during the time period examined for detailed groundwater-flow characterization (i.e., 1997 to 2003). In addition, a number of the LERF wells examined appear to have water tables that currently are below the overlying supra-sediments (Hanford and Ringold formations) and reflect groundwater conditions within the flowtop of the underlying Elephant Mountain basalt (e.g., wells 299-E26-11 and -E34-3).

To evaluate the sensitivity of groundwater-flow direction and hydraulic gradient determinations within LERF, standard frequency (e.g., quarter-annual) Hanford Site water-level data over the 1997 to 2003-year-time period were analyzed. Because well water-level measurements were collected, in some cases over a period of several days, the effects of barometric pressure fluctuations may exert a discernible influence on calculated groundwater-flow direction and hydraulic gradient particularly in low gradient areas as discussed in Spane (2002). 


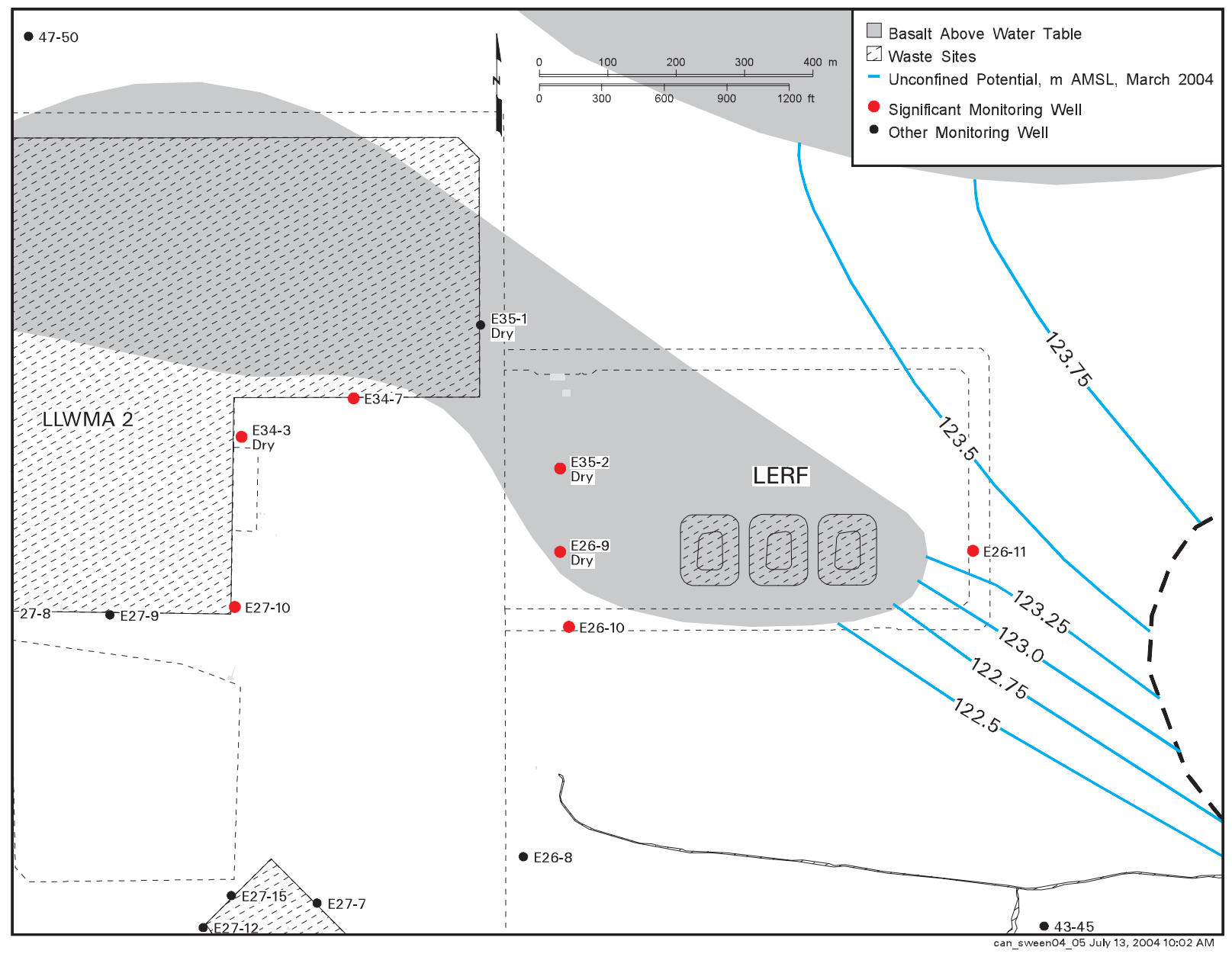

Figure 8.1. Location Map for Well 299-E26-10 and Associated Monitor Well Sites Utilized in the Trend-Surface Analysis

To address these concerns, available RCRA monitor well data were quantitatively evaluated for groundwater-flow characterization using some of the screening criteria listed previously in Spane (1999). Trend-surface analysis was applied to four different LERF monitor well data set groupings. The first dataset (Table 8.2) contains all seven viable LERF monitor wells: 299-E26-9, -E26-10, -E26-11, -E27-10, -E34-7, and -E35-2. Based on the results of sensitivity analysis (not included), two wells (wells 299-E26-11, and -E34-7) were identified as having more significant hydraulic impact on flow direction and gradient. Subsequently, the three remaining datasets examined the effect of removing each well individually and then collectively from the trend-surface analysis results (Table 8.3 omitted well 299-E34-7; Table 8.4 omitted well 299-E26-11; and Table 8.5 omitted both wells).

Table 8.2 lists the results of quantitative trend-surface analysis for all seven LERF viable monitor wells. As indicated, calculated groundwater-flow characteristics are relatively uniform over the seven year period, and indicate a consistent westerly $\left(184^{\circ}\right)$ flow direction and relatively high hydraulic gradient 
Table 8.1. Pertinent Information for Monitor Wells in LERF and Immediate Surrounding Area

\begin{tabular}{|c|c|c|c|c|}
\hline Well & $\begin{array}{l}\text { Top of Casing } \\
\text { Elevation, m, } \\
\text { MSL } \\
\text { (NAVD88) }\end{array}$ & $\begin{array}{l}\text { Well Water-Level } \\
\text { Record Period }\end{array}$ & $\begin{array}{l}\text { Saturated Well- } \\
\text { Screen } \\
\text { Section Elevation, m } \\
\text { MSL (NAVD88) }\end{array}$ & Comments \\
\hline $299-E 26-1^{(a)}$ & 189.14 & $10 / 49-6 / 96$ & $\begin{array}{l}122.31-119.37 \\
(2.94)^{(b)}\end{array}$ & $\begin{array}{l}\text { Saturated well-screen section } \\
\text { based on projected } 3 / 2003 \text { water } \\
\text { level }\end{array}$ \\
\hline 299-E26-9 & 184.85 & $10 / 90-3 / 02$ & $\begin{array}{l}122.71 \\
\text { (bottom of well } \\
\text { screen) }\end{array}$ & Well is currently listed as dry \\
\hline 299-E26-10 & 184.42 & $10 / 90-3 / 03$ & $\begin{array}{c}122.36-120.38 \\
(1.98)\end{array}$ & Top of basalt $\approx 120.9 \mathrm{~m} \mathrm{MSL}$ \\
\hline 299-E26-11 & 183.88 & $10 / 90-3 / 03$ & $\begin{array}{c}121.73-120.03 \\
(1.70)\end{array}$ & Top of basalt $\approx 122.4 \mathrm{~m} \mathrm{MSL}$ \\
\hline 299-E27-10 & 191.43 & $12 / 87-4 / 03$ & $\begin{array}{c}122.34-119.97 \\
(2.37)\end{array}$ & Top of basalt $\approx 117.7 \mathrm{~m} \mathrm{MSL}$ \\
\hline 299-E34-3 & 187.48 & $12 / 87-3 / 03$ & $\begin{array}{c}122.31-121.75 \\
(0.56)\end{array}$ & Top of basalt $\approx 121.9 \mathrm{~m} \mathrm{MSL}$ \\
\hline 299-E34-7 & 185.26 & $12 / 89-4 / 03$ & $\begin{array}{c}122.25-121.95 \\
(0.30)\end{array}$ & Top of basalt $\approx 121.8 \mathrm{~m} \mathrm{MSL}$ \\
\hline 299-E35-2 & 184.61 & $10 / 90-3 / 03$ & $\begin{array}{c}122.41-122.29 \\
(0.12)\end{array}$ & $\begin{array}{l}\text { Well is currently considered to be } \\
\text { dry. Top of basalt } \approx 122.7 \mathrm{~m} \\
\text { MSL }\end{array}$ \\
\hline \multicolumn{5}{|c|}{$\begin{array}{l}\text { (a) Well not used in trend-surface analysis, due to lack of water-level measurements taken during the } 1997-2003 \\
\text { period. } \\
\text { (b) Number in parentheses is saturated thickness; unless otherwise noted, it reflects conditions at } 3 / 2003 \text {; values } \\
\text { are } \pm 0.3 \mathrm{~m} \text {, due to uncertainty in relationship of surface control datum to original ground surface. } \\
\text { MSL = mean sea level. } \\
\text { NAVD } 88 \text { = North American Vertical Datum of } 1988 \text {. }\end{array}$} \\
\hline
\end{tabular}

condition $(9.35 \mathrm{E}-04 \mathrm{~m} / \mathrm{m})$, that may be decreasing slightly with time. The predominant well within the dataset that influences the hydraulic gradient and predominant western groundwater-flow direction is well 299-E26-11.

Table 8.3 presents the calculated results without the effects of well 299-E34-7 in the dataset. Sensitivity analysis suggests that this particular well produces a slightly more northerly flow direction when included in the trend-surface analysis. This is reflective in the average flow direction of $193^{\circ}$ as shown in Table 8.3, with its presence remove from the trend-surface analysis. Again the high hydraulic gradient $(9.49 \mathrm{E}-04 \mathrm{~m} / \mathrm{m})$ and predominant westerly groundwater-flow direction is largely an artifact of inclusion of well 299-E26-11. 
Table 8.2. Groundwater-Flow Characterization Results Based on Trend-Surface Analysis of All Monitor Well Water-Level Measurements in LERF and Immediate Surrounding $\operatorname{Area}^{(a)}$

\begin{tabular}{|c|c|c|c|c|}
\hline Date & $\begin{array}{c}\text { Maximum } \\
\text { Observed Well } \\
\text { Water-Level } \\
\text { Elevation } \\
\text { Difference, m } \\
\end{array}$ & $\begin{array}{l}\text { Flow Direction, } \\
\left(0^{\circ}=\mathrm{E} ; 90^{\circ}=\mathrm{N}\right)\end{array}$ & $\begin{array}{l}\text { Hydraulic } \\
\text { Gradient } \\
(\mathrm{m} / \mathrm{m})\end{array}$ & Comments \\
\hline $6 / 10 / 97$ & 1.308 & $184^{\circ}$ & $1.04 \mathrm{E}-03$ & \\
\hline $6 / 8 / 98$ & 1.222 & $186^{\circ}$ & $9.81 \mathrm{E}-04$ & \\
\hline $3 / 8-9 / 99$ & 1.186 & $193^{\circ}$ & $9.67 \mathrm{E}-04$ & \\
\hline $3 / 22-23 / 00$ & 1.173 & $181^{\circ}$ & $9.09 \mathrm{E}-04$ & \\
\hline $3 / 13-14 / 01$ & 1.096 & $180^{\circ}$ & $8.71 \mathrm{E}-04$ & \\
\hline $3 / 19 / 02$ & 1.110 & $186^{\circ}$ & $9.04 \mathrm{E}-04$ & $\begin{array}{l}\text { Well 299-E34-3 measured } \\
\text { on 5/1/02 }\end{array}$ \\
\hline $3 / 19 / 03$ & 1.068 & $177^{\circ}$ & $8.75 \mathrm{E}-04$ & $\begin{array}{l}\text { Well 299-E26-9 dry; no } \\
\text { measurement available }\end{array}$ \\
\hline $\begin{array}{c}\text { Average Values } \\
\text { (Standard Deviation) }\end{array}$ & $\begin{array}{c}1.166 \\
( \pm 0.083)\end{array}$ & $\begin{array}{c}184^{\circ} \\
\left( \pm 5.2^{\circ}\right)\end{array}$ & $\begin{array}{c}9.35 \mathrm{E}-04 \\
( \pm 6.3 \mathrm{E}-05)\end{array}$ & \\
\hline
\end{tabular}

Table 8.3. Groundwater-Flow Characterization Results Based on Trend-Surface Analysis of All Monitor Well Water-Level Measurements in LERF and Immediate Surrounding Area; Well 299-E34-7 Omitted ${ }^{(a)}$

\begin{tabular}{|c|c|c|c|c|}
\hline Date & $\begin{array}{c}\text { Maximum } \\
\text { Observed Well } \\
\text { Water-Level } \\
\text { Elevation } \\
\text { Difference, } \mathrm{m} \\
\end{array}$ & $\begin{array}{l}\text { Flow Direction, } \\
\left(0^{\circ}=\mathrm{E} ; 90^{\circ}=\mathrm{N}\right)\end{array}$ & $\begin{array}{c}\text { Hydraulic } \\
\text { Gradient } \\
(\mathrm{m} / \mathrm{m}) \\
\end{array}$ & Comments \\
\hline $6 / 10 / 97$ & 1.223 & $195^{\circ}$ & $1.07 \mathrm{E}-03$ & \\
\hline $6 / 8 / 98$ & 1.147 & $196^{\circ}$ & $1.01 \mathrm{E}-03$ & \\
\hline $3 / 8-9 / 99$ & 1.186 & $190^{\circ}$ & $9.59 \mathrm{E}-04$ & \\
\hline $3 / 22-23 / 00$ & $1 . .077$ & $193^{\circ}$ & $9.23 \mathrm{E}-04$ & \\
\hline $3 / 13-14 / 01$ & 1.058 & $187^{\circ}$ & $8.72 \mathrm{E}-04$ & \\
\hline $3 / 19 / 02$ & 1.053 & $197^{\circ}$ & $9.30 \mathrm{E}-04$ & $\begin{array}{l}\text { Well 299-E34-3 measured } \\
\text { on } 5 / 1 / 02\end{array}$ \\
\hline $3 / 19 / 03$ & 1.005 & $192^{\circ}$ & $8.81 \mathrm{E}-04$ & $\begin{array}{l}\text { Well 299-E26-9 dry; no } \\
\text { measurement available }\end{array}$ \\
\hline $\begin{array}{c}\text { Average Values } \\
\text { (Standard Deviation) }\end{array}$ & $\begin{array}{c}1.107 \\
( \pm 0.079) \\
\end{array}$ & $\begin{array}{c}193^{\circ} \\
\left( \pm 3.5^{\circ}\right)\end{array}$ & $\begin{array}{c}9.49 \mathrm{E}-04 \\
( \pm 7.1 \mathrm{E}-05)\end{array}$ & \\
\hline $\begin{array}{l}\text { (a) LERF Monitoring } \\
\text {-E35-2. }\end{array}$ & Network (to & ork): 299-E26 & $26-10,-\mathrm{E} 26$ & -E27-10, E34-3, and \\
\hline
\end{tabular}


Table 8.4 shows the calculated results without the dominant effects of well 299-E26-11 included in the dataset. As indicated, the average flow direction of $121^{\circ}$ indicates a more north-northwesterly flow direction, and relatively low hydraulic gradient $(1.87 \mathrm{E}-04 \mathrm{~m} / \mathrm{m})$ condition.

Table 8.5 presents the calculated results without the dominant effects of well 299-E26-11, and more subtle impact of well 299-E34-7 included in the dataset. As indicated, the average flow direction of $207^{\circ}$ indicates a more west-southwesterly flow direction, and very low hydraulic gradient $(1.10 \mathrm{E}-04 \mathrm{~m} / \mathrm{m})$ condition. The groundwater-flow characterization results were calculated based on a maximum difference in well water-level elevations of $<0.10 \mathrm{~m}$ for all five monitor wells examined. These results should be considered to be highly qualitative because of the relatively small areal difference and the fact that the water-level elevations were not corrected for various factors (borehole deviation, barometric effects), which are known to influence groundwater-flow characterization studies in low hydraulic gradient regions (Spane 1999, 2002).

In summary, the general consensus of the trend-surface analysis of various well datasets indicates a westerly groundwater flow direction, which can vary from a more north-northwesterly direction (Table 8.4) to a west-southwesterly direction (Table 8.5), if the dominating effects of well 299-E26-11 and -E34-7 are removed from the analysis, respectively. Similarly, hydraulic gradient conditions range from $\approx 1 \mathrm{E}-03$ to $1 \mathrm{E}-04 \mathrm{~m} / \mathrm{m}$ for all well datasets considered. For purposes of analyzing the tracer pumpback test at well 299-E26-10 (Section 6.1), the average hydraulic gradient condition of $1.0 \mathrm{E}-04 \mathrm{~m} / \mathrm{m}$ was used, which omits the dominant effects caused by well 299-E26-11 and -E34-7 (Table 8.5) from the trend-surface analysis results. As an additional observation concerning aquifer continuity, the similarity in well dynamic responses for wells currently monitoring only the upper Elephant Mountain basalt flowtop (e.g., well 299-E26-11) and wells monitoring only overlying supra-sediments (Figure 8.2) suggests that the Elephant Mountain basalt flowtop is hydraulically communicative with the unconfined aquifer; and, therefore, may be considered as part of the unconfined aquifer flow system. 
Table 8.4. Groundwater-Flow Characterization Results Based on Trend-Surface Analysis of All Monitor Well Water-Level Measurements in LERF and Immediate Surrounding Area; Well 299-E26-11 Omitted ${ }^{\text {(a) }}$

\begin{tabular}{||c|c|c|c|c|}
\hline \hline & $\begin{array}{c}\text { Maximum } \\
\text { Observed Well } \\
\text { Water-Level } \\
\text { Elevation } \\
\text { Difference, } \mathrm{m}\end{array}$ & $\begin{array}{c}\text { Flow Direction, } \\
\left(0^{\circ}=\mathrm{E} ; 90^{\circ}=\mathrm{N}\right)\end{array}$ & $\begin{array}{c}\text { Hydraulic } \\
\text { Gradient } \\
(\mathrm{m} / \mathrm{m})\end{array}$ & \multicolumn{1}{|c|}{ Comments } \\
\hline \hline $6 / 10 / 97$ & 0.128 & $112^{\circ}$ & $1.96 \mathrm{E}-04$ & \\
\hline $6 / 8 / 98$ & 0.106 & $109^{\circ}$ & $1.51 \mathrm{E}-04$ & \\
\hline $3 / 19 / 02$ & 0.130 & $132^{\circ}$ & $1.98 \mathrm{E}-04$ & $\begin{array}{l}\text { Well 299-E34-3 measured } \\
\text { on 5/1/02; not included in } \\
\text { analysis }\end{array}$ \\
\hline $3 / 19 / 03$ & 0.159 & $132^{\circ}$ & $2.03 \mathrm{E}-04$ & $\begin{array}{l}\text { Well 299-E26-9 dry; no } \\
\text { measurement available }\end{array}$ \\
\hline $\begin{array}{c}\text { Average Values } \\
\text { (Standard Deviation) }\end{array}$ & $\begin{array}{c}0.131 \\
( \pm 0.022)\end{array}$ & $121^{\circ}$ & $\begin{array}{c}1.87 \mathrm{E}-04 \\
\left( \pm 12.5^{\circ}\right)\end{array}$ & $( \pm 2.4 \mathrm{E}-05)$ \\
\hline (a) LERF Monitoring Well Network (total network): 299-E26-9, -E26-10, -E27-10, E34-3, -E34-7, and -E35-2. \\
\hline
\end{tabular}

Table 8.5. Groundwater-Flow Characterization Results Based on Trend-Surface Analysis of All Monitor Well Water-Level Measurements in LERF and Immediate Surrounding Area; Wells 299-E26-11 and-E34-7 Omitted ${ }^{(\text {a) }}$

\begin{tabular}{|c|c|c|c|c||}
\hline \hline & $\begin{array}{c}\text { Maximum } \\
\text { Observed Well } \\
\text { Water-Level } \\
\text { Elevation } \\
\text { Difference, } \mathrm{m}\end{array}$ & $\begin{array}{c}\text { Flow Direction, } \\
\left(0^{\circ}=\mathrm{E} ; 90^{\circ}=\mathrm{N}\right)\end{array}$ & $\begin{array}{c}\text { Hydraulic } \\
\text { Gradient } \\
(\mathrm{m} / \mathrm{m})\end{array}$ & \multicolumn{1}{||}{ Comments } \\
\hline \hline $6 / 10 / 97$ & 0.043 & $178^{\circ}$ & $6.59 \mathrm{E}-05$ & \\
\hline $6 / 8 / 98$ & 0.031 & $200^{\circ}$ & $4.59 \mathrm{E}-05$ & \\
\hline $3 / 19 / 02$ & 0.055 & $258^{\circ}$ & $1.93 \mathrm{E}-04$ & $\begin{array}{l}\text { Well 299-E34-3 measured } \\
\text { on 5/1/02; not included in } \\
\text { analysis }\end{array}$ \\
\hline $3 / 19 / 03$ & 0.096 & $193^{\circ}$ & $1.37 \mathrm{E}-04$ & $\begin{array}{l}\text { Well 299-E26-9 dry; no } \\
\text { measurement available }\end{array}$ \\
\hline $\begin{array}{c}\text { Average Values } \\
\text { (Standard Deviation) }\end{array}$ & $\begin{array}{c}0.056 \\
( \pm 0.028)\end{array}$ & $\begin{array}{c}207^{\circ} \\
\left( \pm 35.1^{\circ}\right)\end{array}$ & $\begin{array}{c}1.10 \mathrm{E}-04 \\
( \pm 6.8 \mathrm{E}-05)\end{array}$ & \\
\hline (a) LERF Monitoring Well Network (total network): 299-E26-9, -E26-10,-E27-10, E34-3, and -E35-2. \\
\hline
\end{tabular}




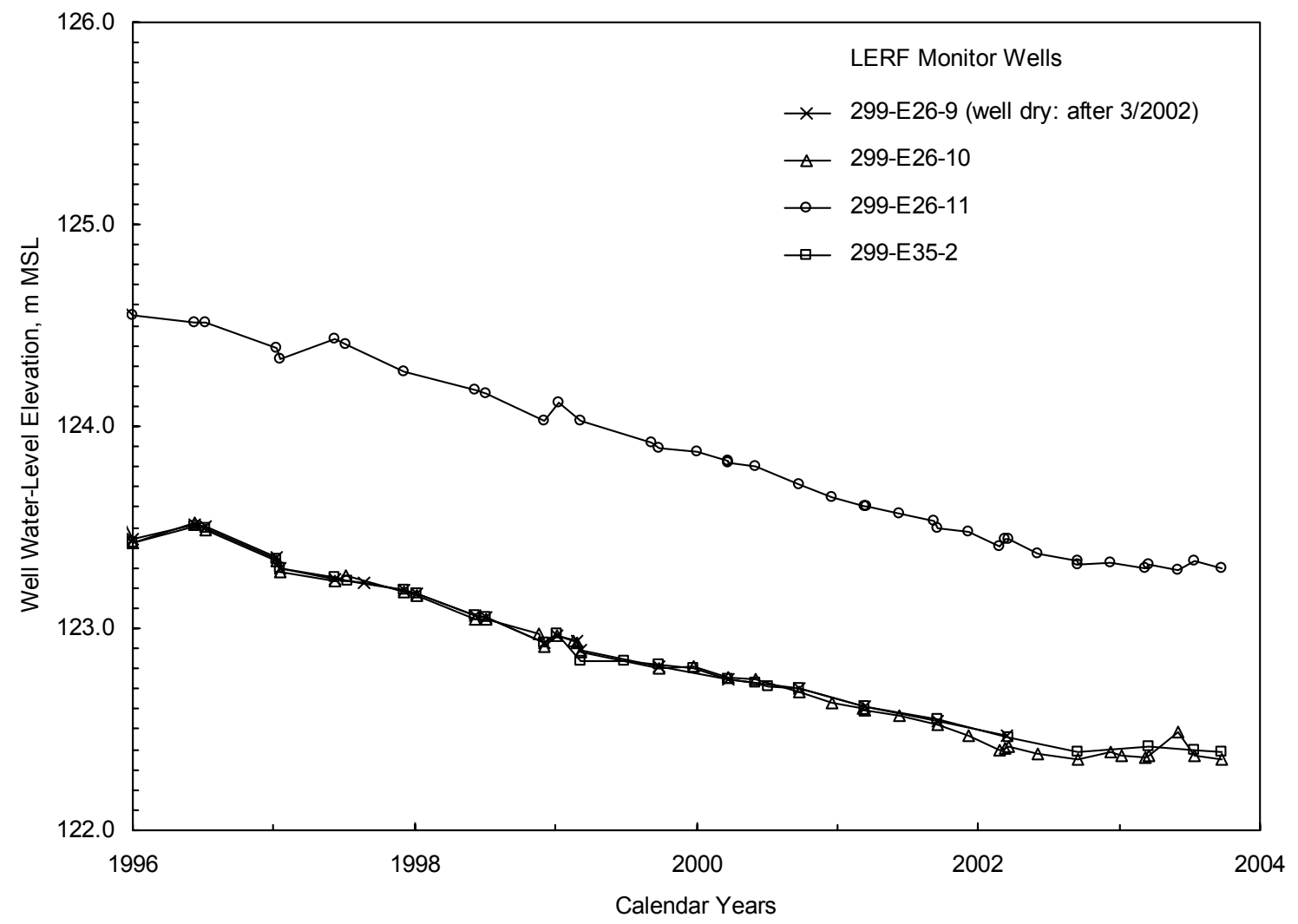

Figure 8.2. Dynamic Water-Level Elevation Plot (1996 - 2003) for Selected Wells Utilized in the Trend-Surface Analysis 


\subsection{Conclusions}

The detailed hydrologic characterization of the Hanford Site's unconfined aquifer system conducted during FY 2003 included slug tests, a single-well tracer test (i.e., including tracer-dilution, tracerpumpback, and in-well vertical flow assessments), and a constant-rate pumping test. Hydraulic property estimates obtained from the detailed tests include hydraulic conductivity, transmissivity, specific yield, effective porosity, in-well lateral groundwater-flow velocity, and in-well and aquifer groundwater-flow velocity. In addition, the characteristics of local groundwater flow (i.e., hydraulic gradient, flow direction) were determined for the general LERF site that surrounds the well site selected for detailed tracer test characterization (i.e., well 299-E26-10).

\subsection{Slug-Test and Constant-Rate Pumping Test Results}

Slug-test results provided hydraulic conductivity estimates that ranged between 3.0 and $64.1 \mathrm{~m} /$ day for the two 200-West Area wells that are representative of the Ringold gravel Unit E. These estimates are consistent with previously cited hydraulic conductivity values listed for this hydrogeologic unit in the 200-West Area (e.g., DOE/RL 1993; 200-West Area, 0.02 to $61 \mathrm{~m} /$ day). Slug test results for the four 200-East Area wells tested during FY 2003 provided hydraulic conductivity estimates for the Hanford formation that ranged between 39.8 and $104 \mathrm{~m} /$ day. This high $\mathrm{K}$ estimate is consistent with previously reported (Spane et al. 2001a, 2001b, 2002, 2003) high hydraulic conductivity values for the 200-East Area. As noted in Section 2.2), these high $\mathrm{K}$ estimate values are reflective of the preponderance of higher permeability gravel and sand units within the Hanford formation. In addition, one 200-East Area well was tested that provided hydraulic conductivity estimates the ranged between 5.85 and $6.80 \mathrm{~m} /$ day that are representative of the Elephant Mountain basalt flowtop. These results are consistent with previously reported hydraulic property values for the Elephant Mountain basalt (Spane and Vermeul 1994; Spane and Webber 1995)

For slug tests exhibiting over-damped response characteristics, estimated hydraulic conductivity values obtained using the Bouwer and Rice analytical method are generally less reliable than corresponding estimates obtained using the type-curve method as discussed in Hyder and Butler 1995 and Butler 1998. For this reason, more reliance should be attributed to estimates from the type-curve analysis method for over-damped slug tests. In addition, the three FY 2003 high K analysis results for Hanford Site wells exhibiting under or critically damped response characteristics may under-estimate actual hydraulic property conditions. This is due to the pressure probe placement during these tests which was $\sim 2 \mathrm{~m}$ below the water table. For such high-K settings, pressure probe settings at these depths may be susceptible to fluid-column acceleration effects that are not accounted form in the High-K analytical method. Hydraulic conductivity estimates for these tests, therefore, should be considered minimum values for hydraulic conductivity estimates.

A comparison of the slug-test-derived hydraulic conductivity estimate at well 299-E26-10 (average type-curve analysis value; $\mathrm{K}=39.8 \mathrm{~m} /$ day) with the value obtained from the constant-rate pumping test $(\mathrm{K}=36.2 \mathrm{~m} /$ day $)$ indicates a very close correspondence. This is well within previous, more extensive comparisons, between the two test methods (e.g., as noted in Spane et al. 2002). The general comparison 
relationship exhibited between slug and pumping test estimates also falls within the error range commonly reported for slug tests in aquifer characterization studies (i.e., within a factor of $\sim 2$ or less [e.g., Butler 1996]).

Analysis of the constant-rate pumping test results for well 299-E26-10 indicates a transmissivity and specific yield value of $71.6 \mathrm{~m}^{2} /$ day and 0.128 , respectively. The unconfined aquifer at this location is extremely thin (i.e., $1.98 \mathrm{~m}$ ). No hydraulic boundaries or response characteristics indicative of detachment or perched-water conditions were exhibited during the performance of the constant-rate pumping test. These results suggest that the saturated sediments of the Hanford formation at this location are part of the larger, site-wide unconfined aquifer system.

\subsection{Single-Well Tracer Test Results}

A detailed single-well tracer test was conducted at well 299-E26-10 to determine groundwater-flow velocity and effective porosity characteristics of the unconfined aquifer within this general area of the LERF facility. The tracer test consisted of two components: a tracer-dilution/drift phase for determining in-well groundwater flow velocity conditions and the relative vertical distribution hydraulic conductivity within the saturated well-screen section; and a tracer-pumpback component for determining the effective porosity and groundwater-flow velocity within the aquifer.

The tracer-dilution test was designed to examine specific aquifer test site conditions that might affect groundwater-flow at this LERF well site location. These specific site conditions included: the presence of two hydrogeologic units within the well-screen section (i.e., Elephant Mountain flowtop and Hanford formation sediments); very small aquifer thickness (i.e., thickness, b, variations in surrounding region); low-hydraulic gradient causing increased importance of molecular diffusion; and possible proximity to hydrologic aquifer boundary. The tracer-dilution test results indicated: an average in-well lateral groundwater-flow velocity ( $\mathrm{v}_{\mathrm{w}}=0.0024$ to $0.0042 \mathrm{~m} /$ day); and a slight downward in-well groundwaterflow condition within the Hanford formation section $\left(\mathrm{v}_{\mathrm{v}}=0.0002 \mathrm{~m} / \mathrm{min}\right)$. These extremely low, in-well flow velocity estimates are believed reflective of the low-hydraulic gradient conditions (i.e., $1.9 \mathrm{E}-4 \mathrm{~m} / \mathrm{m}$ ) within the unconfined aquifer/test vicinity. A comparison of the in-well tracer-dilution patterns also suggests that the $\sim 0.5 \mathrm{~m}$ of Elephant Mountain basalt flowtop has a considerably lower hydraulic conductivity than the overlying Hanford formation sediments.

Results from the tracer-pumpback test provided estimates for effective porosity and aquifer groundwater-flow velocity of 0.373 and $0.0184 \mathrm{~m} /$ day $(6.7 \mathrm{~m} /$ year $)$, respectively. Because of the previously cited test site conditions and the fact that the calculated $n_{e}$ and $v_{a}$ values are reflective of a region $\sim 1.6 \mathrm{~m}$ from the well, these property values may be considered to be qualitative estimates.

Quantitative groundwater-flow characterization provided by trend-surface analysis of historical water-table elevation analysis of selected LERF monitoring wells surrounding the well 299-E26-10 test site substantiates a low-hydraulic gradient condition for the area. Results from the trend-surface analysis of a representative set of five surrounding wells, together with test well 299-E26-10, indicate a consistent value of hydraulic gradient of $0.00019 \mathrm{~m} / \mathrm{m}$, and a predominant northwesterly groundwater flow direction, which parallels the basalt subcrop pattern (i.e., basalt surface above the water table). Additionally, the similarity in well dynamic responses for wells currently monitoring only the upper Elephant Mountain 
basalt flowtop (e.g., well 299-E26-11) and wells monitoring only overlying supra-basalt sediments (Figure 8.2) suggests that the Elephant Mountain basalt flowtop is hydraulically communicative with the unconfined aquifer and, therefore, may be considered as part of the unconfined aquifer flow system with the LERF vicinity. 


\subsection{References}

Abriola LM and GF Pinder. 1982. "Calculation of velocity in three space dimensions from hydraulic head measurements.” Ground Water 20(2):205-213.

Bourdet DJ, A Ayoub, and YM Pirard. 1989. "Use of pressure derivative in well-test interpretation." SPE Formation Evaluation June 1989:293-302.

Bouwer H. 1989. “The Bouwer and Rice slug test - an update.” Ground Water 27(3):304-309.

Bouwer H. 1996. "Discussion of Bouwer and Rice slug test review articles." Ground Water 34(1):171.

Bouwer H and RC Rice. 1976. "A slug test for determining hydraulic conductivity of unconfined aquifers with completely or partially penetrating wells." Water Resources Research 12(3):423-428.

Brown DL, TN Narasimhan, and Z Demir. 1995. "An evaluation of the Bouwer and Rice method of slug test analysis." Water Resources Research 31(5):1239-1246.

Butler JJ, Jr. 1990. "The role of pumping tests in site characterization: some theoretical considerations." Ground Water 28(3):394-402.

Butler JJ, Jr. 1996. "Slug tests in site characterization: some practical considerations.” Environmental Geosciences 3(3):154-163.

Butler JJ, Jr. 1997. The design, performance, and analysis of slug tests. Lewis Publishers, CRC Press, Boca Raton, Florida.

Butler, JJ, Jr. and EJ Garnett. 2000. Simple procedures for analysis of slug tests in formations of high hydraulic conductivity using spreadsheet and Scientific Graphics Software. Open-file Report 2000-40, Kansas Geological Survey, Lawrence, Kansas.

Butler, JJ, Jr., GC Bohling, ZH Hyder, and CD McElwee. 1994. "The use of slug tests to describe vertical variations in hydraulic conductivity." Journal of Hydrology 156:137-162

Butler, JJ, Jr., EJ Garnett, and JM Healey. 2003. “Analysis of slug tests in formations of high hydraulic conductivity." Ground Water 41(5):620-630.

Butler JJ, CD McElwee, and W Liu. 1996. "Improving the quality of parameter estimates obtained from slug tests." Ground Water 34(3):480-490.

Cole, C. R., M. P. Bergeron, C. J. Murray, P. D. Thorne, S. K. Wurstner, P. Rogers. 2001. Uncertainty analysis framework Hanford's site-wide groundwater flow and transport model. PNNL-13641, Pacific Northwest National Laboratory, Richland, Washington. 
Connelly MP, BH Ford, and JV Borghese. 1992b. Hydrogeologic model for the 200-West groundwater aggregate area. WHC-SD-EN-TI-014, Rev. 0, Westinghouse Hanford Company, Richland, Washington.

Connelly MP, JV Borghese, CD Delaney, BH Ford, JW Lindberg, and SJ Trent. 1992a. Hydrogeologic model for the 200-East groundwater aggregate area. WHC-SD-EN-TI-019, Rev. 0, Westinghouse Hanford Company, Richland, Washington.

Cooper HH, Jr. and CE Jacob. 1946. "A generalized graphical method for evaluating formation constants and summarizing well-field history." American Geophysical Union, Transactions 27(4):526-534.

DOE/RL. 1993. 200 West groundwater aggregate area management study report. DOE/RL-92-16, Rev. 0, U.S. Department of Energy, Richland Operations Office, Richland, Washington.

DOE. 2002. Standardized Stratigraphic Nomenclature for Post-Ringold-Formation Sediments Within the Central Pasco Basin. DOE/RL-2002-39, U.S. Department of Energy, Richland, Washington.

Drost W, D Klotz, A Koch, H Moser, F Neumaier, and W Rauert. 1968. "Point dilution methods of investigating groundwater flow by means of radioisotopes." Water Resources Research 4(1):125-146.

Freeze RA and JA Cherry. 1979. Groundwater. Prentice-Hall, Englewood Cliffs, New Jersey.

Gephart RE, FA Spane, LS Leonhart, DA Palombo, and SR Strait. 1979. "Pasco Basin hydrology." In Hydrologic studies within the Columbia plateau, Washington: An integration of current knowledge, pp. III-1 to III-236. RHO-BWI-ST-5, Rockwell Hanford Operations, Richland, Washington.

Gilmore TJ, DR Newcomer, SK Wurstner, and FA Spane, Jr. 1992. Calculation of groundwater discharge to the Columbia River in the 100-N area. PNL-8057, Pacific Northwest Laboratory, Richland, Washington.

Graham MJ, GV Last, and KR Fecht. 1984. An assessment of aquifer intercommunication in the B-Pond-Gable Mountain Pond area of the Hanford site. RHO-RE-ST-12P, Rockwell Hanford Operations, Richland, Washington.

Güven O, RW Falta, FJ Molz, and JG Melville. 1985. "Analysis interpretation of single-well tracer tests in stratified aquifers." Water Resources Research 21(5):676-684.

Guyonnet D, S Mishra, and J McCord. 1993. "Evaluating the volume of porous medium investigated during slug tests." Ground Water 31(4):627-633.

Halevy E, H Moser, O Zellhofer, and A Zuber. 1966. "Borehole dilution techniques - a critical review." In Isotopes in Hydrology, International Atomic Energy Agency, Vienna, Austria.

Hall SH. 1993. "Single well tracer tests in aquifer characterization." Ground Water Monitoring \& Review 13(2):118-124. 
Hall SH, SP Luttrell, and WE Cronin. 1991. "A method for estimating effective porosity and groundwater velocity." Ground Water 29(2):171-174.

Hantush MS. 1964. "Hydraulics of wells." Advances in Hydroscience (VT Chow, ed) 1:282-433, Academic Press, New York.

Hartman MJ, LF Morasch, and WD Webber (eds.). 2004. Hanford Site groundwater monitoring for fiscal year 2003. PNNL-14548, Pacific Northwest National Laboratory, Richland, Washington.

Hyder Z and JJ. Butler, Jr. 1995. "Slug tests in unconfined formations: An assessment of the Bouwer and Rice technique." Ground Water 33(1):16-22.

In-Situ Inc. 1991. WATER-VEL ${ }^{T M}$ groundwater velocity. ISI-GWV-2.21-1, Laramie, Wyoming.

Jacob, CE. 1963. "Determining the permeability of water-table aquifers." In Methods of Determining Permeability, Transmissibility, and Drawdown, U.S. Geological Survey, Water-Supply Paper 1536$\mathrm{I}: 245-271$.

Karasaki K, JCS Long, and PA Witherspoon. 1988. “Analytical Models of Slug Tests.” Water Resources Research 24(1):115-126.

Kearl PM, JJ Dexter, and JE Price. 1988. Procedures, analysis, and comparison of groundwater velocity measurement methods for unconfined aquifers. UNC/GJ-TMC-3, UNC Geotech, Grand Junction, Colorado.

Kelly WE and I Bogardi. 1989. "Flow directions with a spreadsheet." Ground Water-Computer Notes 27(2):245-247.

Leap DI and PG Kaplan. 1988. “A single-well tracing method for estimating regional advective velocity in a confined aquifer: Theory and preliminary laboratory verification." Water Resources Research 24(7):993-998.

Lindsey KA. 1995. Miocene- to Pliocene-aged suprabasalt sediments of the Hanford Site, south-central Washington. BHI-00184, Bechtel Hanford Inc., Richland, Washington.

Lindsey KA, BN Bjornstad, JW Lindberg, and KM Hoffman. 1992. Geologic setting of the 200-East area: An update. WHC-SD-EN-TI-012, Rev. 0, Westinghouse Hanford Company, Richland, Washington.

Liu WZ and JJ Butler, Jr. 1995. The KGS model for slug tests in partially penetrating wells (Version 3.0). Kansas Geological Survey Computer Series Report 95-1, Lawrence, Kansas.

McElwee CD. 2001. “Application of a nonlinear slug test model.” Ground Water 39(5):737-744.

McElwee CD and MA Zenner. 1998. "A nonlinear model for analysis of slug-test data." Water Resources Research 34(1):55-66. 
Moench AF. 1997. "Flow to a well of finite diameter in a homogeneous, anisotropic water-table aquifer." Water Resources Research 33(6):1397-1407.

Moench AF and PA Hsieh. 1985. "Analysis of slug test data in a well with finite-thickness skin." In Memoirs Hydrogeology of Rocks of Low Permeability, January 7-12, 1985, Tucson, Arizona; International Association of Hydrogeologists 17(1):17-29.

Molz FJ, JG Melville, O Güven, RD Crocker, and KT Matteson. 1985. "Design and performance of single-well tracer tests at the Mobile site." Water Resources Research 21(10):1497-1502.

Neuman SP. 1972. "Theory of flow in unconfined aquifers considering delayed response of the water table." Water Resources Research 8(4):1031-1045.

Neuman SP. 1974. "Effect of partial penetration of flow in unconfined aquifer considering delayed gravity response." Water Resources Research 10(2):303-312.

Neuman SP. 1975. "Analysis of pumping test data from anisotropic unconfined aquifers considering delayed gravity response." Water Resources Research 11(2):329-342.

Novakowski KS. 1989. "Analysis of pulse interference tests.” Water Resources Research 25(11):2377-2387.

Pickens JF, and GE Grisak. 1981. "Scale-dependent dispersion in a stratified granular aquifer." Water Resources Research 17(4):1191-1211.

Rasmussen TC and LA Crawford. 1997. "Identifying and removing barometric pressure effects in confined and unconfined aquifers." Ground Water 35(3):502-511.

Resource Conservation and Recovery Act, as amended, Public Law 94-580, 90 Stat. 2795, 42 USC 6901 et seq.

Spane FA, Jr. 1993. Selected hydraulic test analysis techniques for constant-rate discharge tests. PNL-8539, Pacific Northwest Laboratory, Richland, Washington.

Spane FA, Jr. 1996. "Applicability of slug interference tests for hydraulic characterization of unconfined aquifer: (1) Analytical assessment.” Ground Water 34(1):66-74.

Spane FA, Jr. 1999. Effects of barometric fluctuations on well water-level measurements and aquifer test data. PNNL-13078, Pacific Northwest National Laboratory, Richland, Washington.

Spane FA, Jr. 2002. “Considering barometric pressure in groundwater flow investigations." Water Resources Research 38(6), 14:1-18.

Spane FA, Jr. and VR Vermeul. 1994. Summary and evaluation of hydraulic property data available for the Hanford Site upper basalt confined aquifer system. PNL-10158, Pacific Northwest Laboratory, Richland, Washington. 
Spane FA, Jr. and WD Webber. 1995. Hydrochemistry and hydrogeologic conditions within the Hanford Site upper basalt confined aquifer system. PNL-10817, Pacific Northwest Laboratory, Richland, Washington.

Spane FA, Jr. and SK Wurstner. 1993. "DERIV: A program for calculating pressure derivatives for use in hydraulic test analysis." Ground Water 31(5):814-822.

Spane FA, Jr., PD Thorne, and DR Newcomer. 2001a. Results of detailed hydrologic characterization tests - fiscal year 1999. PNNL-13378, Pacific Northwest National Laboratory, Richland, Washington.

Spane FA, Jr., PD Thorne, and DR Newcomer. 2001b. Results of detailed hydrologic characterization tests - fiscal year 2000. PNNL-13514, Pacific Northwest National Laboratory, Richland, Washington.

Spane FA, Jr., PD Thorne, and DR Newcomer. 2002. Results of detailed hydrologic characterization tests - fiscal year 2001. PNNL-14113, Pacific Northwest National Laboratory, Richland, Washington.

Spane, F.A.. Jr., P.D. Thorne, and D.R. Newcomer. 2003. Results of detailed hydrologic characterization tests - FY 2002. PNNL-14186. Pacific Northwest National Laboratory, Richland, Washington

Spane FA, Jr., PD Thorne, and LC Swanson. 1996. "Applicability of slug interference tests for hydraulic characterization of unconfined aquifer: (2) Field test examples." Ground Water 34(5):925-933.

Springer RK and LW Gelhar. 1991. "Characterization of large-scale aquifer heterogeneity in glacial outwash by analysis of slug tests with oscillatory response, Cape Cod, Massachusetts." In U.S. Geological Survey Water Resources Investigations. Report 91-4034:36-40.

Sweeney MD. 1993. Site characterization report for the Liquid Effluent Retention Facility. WHC-SDEN-EV-024, Westinghouse Hanford Company, Richland, Washington.

Theis CV. 1935. "The relationship between the lowering of the piezometric surface and the rate and duration of discharge of a well using ground-water storage." American Geophysical Union, Transactions, 2:519-524; reprinted in Society of Petroleum Engineers, "Pressure Transient Testing Methods", SPE Reprint Series (14):27-32, Dallas, Texas.

Thorne PD, MA Chamness, FA Spane, Jr., VR Vermeul, and WD Webber. 1993. Three-dimensional conceptual model for the Hanford Site unconfined aquifer system, FY 93 status report. PNL-8971, Pacific Northwest Laboratory, Richland, Washington.

Van der Kamp G. 1976. "Determining aquifer transmissivity by means of well response tests: The underdamped case." Water Resources Research 12(1):71-77.

Weeks EP. 1979. "Barometric fluctuations in wells tapping deep unconfined aquifers." Water Resources Research 15(5):1167-1176. 
Williams BA, BN Bjornstad, R Schalla, and WD Webber. 2000. Revised hydrogeology for the suprabasalt aquifer system, 200-East area and vicinity, Hanford Site, Washington. PNNL-12261, Pacific Northwest National Laboratory, Richland, Washington.

Zurbuchen BR, VA Zlotnik, and JJ Butler, Jr. 2002. "Dynamic interpretation of slug tests in highly permeable aquifers.” Water Resources Research 38(3), 7:1-18. 


\section{Distribution}

No. of

\section{Copies}

\section{OFFSITE}

Confederated Tribes of the Umatilla Indian Reservation

P.O. Box 638

Pendleton, OR 97801

ATTN: S. Harris

B. W. Drost

Geological Survey

U.S. Department of the Interior

1201 Pacific Avenue, Suite 600

Tacoma, WA 98402

W. N. Herkelrath

Geological Survey

U.S. Department of the Interior

345 Middlefield Road, MS 496

Menlo Park, CA 94025

Idaho National Engineering and Environmental Laboratory

Lockheed Martin Idaho Technology Co.

P.O. Box 1625

Idaho Falls, ID 83415-2107

ATTN: J. B. Sisson

Nez Perce Tribe

Environmental Restoration/Waste

Management

P.O. Box 365

Lapwai, ID 83540-0365

ATTN: P. Sobotta
No. of

Copies

2 T. Kirk

Washington State

Department of Ecology

Water Resources Program

Central Regional Office

15 W. Yakima Avenue, Suite 200

Yakima, WA 98902-3401

Washington State

Department of Health

Division of Radiation Protection

P.O. Box 47827

Olympia, WA 98504-7827

ATTN: D. McBaugh

Wanapum People

Grant County P.U.D.

P.O. Box 878

Ephrata, WA 98823

ATTN: L. Seelatsee

Yakama Indian Nation

Environmental Restoration/Waste

Management Program

2802 Main Street

Union Gap, WA 98903

ATTN: W. Rigsby

\section{ONSITE}

\section{DOE Office of River Protection}

R. M. Yasek

H6-60 
No. of

Copies

6 DOE Richland Operations Office

R. D. Hildebrand A6-38

J. G. Morse A6-38

K. M. Thompson A6-38

A. C. Tortoso A6-38

Public Reading Room (2) H2-53

2 CH2M HILL Hanford, Inc.
A. J. Knepp
E6-35
D. J. Meyer
E6-35

2 Duratek Federal Services, Inc.

M. G. Gardner

H1-11

S. H. Worley

H1-11

5 Fluor Hanford, Inc.

R. L. Jackson

E6-35

J. V. Borghese

E6-35

V. G. Johnson

K6-96

L. C. Swanson

E6-35

J. C. Winterhalder

E6-35

\section{U.S. Environmental Protection Agency}

D. A. Faulk

B5-01

2 Washington State Department of Ecology

J. Caggiano

$\mathrm{H} 0-57$

D. Goswami

$\mathrm{H} 0-57$
No. of

Copies

30 Pacific Northwest National Laboratory

D. B. Barnett K6-81

M. P. Bergeron K9-36

P. E. Dresel K6-96

M. J. Fayer K9-33

M. D. Freshley K9-36

J. S. Fruchter K6-96

T. J Gilmore K6-81

M. J. Hartman K6-96

C. T. Kincaid K9-33

G. V. Last K6-81

J. W. Lindberg K6-81

S. P. Luttrell K6-96

J. P. McDonald K6-96

S. M. Narbutovskih K6-96

D. R. Newcomer K6-96

R. E. Peterson K6-96

J. T. Rieger K6-96

R. M. Smith K6-96

F. A. Spane, Jr. (3) K6-96

D. L. Stewart K6-96

M. D. Sweeney K6-81

P. D. Thorne K9-33

E. C. Thornton K6-96

W. D. Webber K6-96

B. A. Williams K6-81

S. K. Wurstner K9-36

Hanford Technical Library (2) P8-55 